\title{
Stem Cell-Based and Tissue Engineering Approaches for Skeletal Muscle Repair
}

\section{Book Chapter}

Author(s):

Domenig, Seraina A.; Palmer, Andrew S.; Bar-Nur, Ori (D)

Publication date:

2020

Permanent link:

https://doi.org/10.3929/ethz-b-000430184

Rights / license:

In Copyright - Non-Commercial Use Permitted

Originally published in:

Reference Series in Biomedical Engineering, https://doi.org/10.1007/978-3-030-18512-1_19-1 


\title{
Stem Cell-Based and Tissue Engineering Approaches for Skeletal Muscle Repair
}

\author{
Seraina A. Domenig, Andrew S. Palmer, and Ori Bar-Nur
}

\section{Contents}

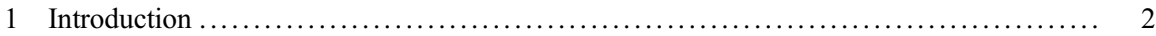

2 Cell Replacement Therapy for the Treatment of Muscle Disorders .................. 4

2.1 Myoblast Transplantation for the Treatment of Duchenne Muscular Dystrophy .... . 5

2.2 Addressing Translational Roadblocks for Myoblast Transplantation ............... 7

2.3 Clinical Procedures Involving Autologous Myoblast Transplantation ............. 15

2.4 Further Considerations for Improvement of Myoblast Transplantation ............ 17

3 Engraftment of Freshly Isolated Satellite Cells for Muscle Regeneration .............. 17

4 Generation of Myogenic Precursors from Pluripotent Stem Cells .................... 20

5 Direct Reprogramming of Somatic Cells into Myogenic Progenitors .................. 23

6 Maintaining Satellite Cell Potency In Vitro .................................... 25

6.1 Basement Membrane Proteins that Support an Undifferentiated Satellite Cell State ... 26

6.2 Inhibition of Satellite Cell Differentiation by Small Molecules, Ligands,

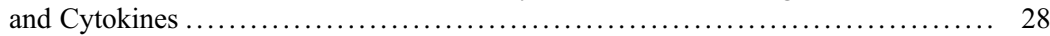

6.3 Genetic Alteration that Support Satellite Cell Self-Renewal and Regeneration .... . . 31

7 Enhancing Muscle Stem Cell Engraftment Using Biomaterials ...................... 32

8 Stem Cell-Based Approaches to Engineer Skeletal Muscle Tissue .................... 35

8.1 Engineering Skeletal Muscle Tissue In Vitro Using Myogenic Precursors ......... 36

8.2 Vascularization of Skeletal Muscle Tissue Constructs ......................... 37

8.3 Innervation of Skeletal Muscle Tissue Constructs ............................ 39

8.4 Integrative Tissue Engineering Approaches to Treat VML .................... 40

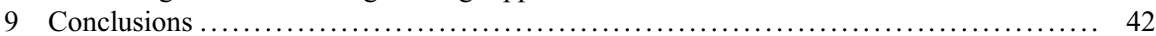

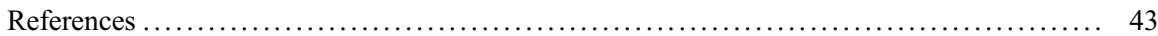

\section{Abstract}

Skeletal muscle tissue exhibits significant regeneration capacity upon injury or disease. This intrinsic regeneration potential is orchestrated by stem cells termed satellite cells, which undergo activation and differentiation in response to muscle

\footnotetext{
S. A. Domenig $\cdot$ A. S. Palmer $\cdot$ O. Bar-Nur $(\bowtie)$

Laboratory of Regenerative and Movement Biology, Institute of Human Movement Sciences and Sport, Department of Health Sciences and Technology, Swiss Federal Institute of Technology (ETH) Zurich, Schwerzenbach, Switzerland e-mail: seraina.domenig@hest.ethz.ch; andrew.palmer2011@gmail.com; ori.bar-nur@hest.ethz.ch
} 
insult, giving rise to fusion-competent myogenic progenitors responsible for tissue rejuvenation. Skeletal muscle diseases such as Duchenne muscular dystrophy are characterized by progressive loss of muscle mass which precipitates reduced motility, paralysis, and in some occurrences untimely death. A manifold of muscle pathologies involve a failure to efficiently regenerate the muscle tissue, rendering stem cell-based approaches an attractive therapeutic strategy. Here we will present past and contemporary methods to treat skeletal muscle degeneration by stem cell therapy, covering prominent challenges facing this technology and potential means to overcome current hurdles. A primary focus of this chapter is directed toward illustrating innovative ways to utilize stem cells alone or in conjunction with biomaterials and tissue engineering techniques to remedy Duchenne muscular dystrophy or volumetric muscle loss.

Human locomotion is carried out by skeletal muscle, a soft tissue composed of postmitotic multinucleated myofibers that contract to generate movement. In addition, skeletal muscle tissue contains mononucleated muscle resident cells in the form of fibroadipogenic progenitors, satellite, and endothelial and hematopoietic cells which play pivotal roles in skeletal muscle tissue homeostasis and repair (Fig. 1) (Giordani et al. 2019; Dell'Orso et al. 2019; Wosczyna and Rando 2018; Rubenstein et al. 2020).

Adult skeletal muscle harbors a high propensity for regeneration, which is dependent on resident stem cells within the skeletal muscle tissue known as satellite cells (Mauro 1961). These unique cells are located between the sarcolemma and basal lamina and are typically quiescent under homeostatic conditions, undergoing activation and proliferation during injury or disease to repair the tissue (Snow 1978; Schultz et al. 1978). Skeletal muscle regeneration follows a well-defined process via a myogenic differentiation program. In adult skeletal muscle, this process initiates when quiescent satellite cells (QSCs) undergo activation to form transient-amplifying activated satellite cells (ASCs) also known as myoblasts. These progenitors can further differentiate into myocytes, which are fusion-competent cells that can merge with muscle fibers to regenerate the tissue (Comai and Tajbakhsh 2014; Yin et al. 2013). This unique process is governed by key transcription factors specific to the myogenic program. QSCs express high levels of the transcription factor Paired Box Protein 7 (Pax7) as well as other unique genes such as Sprouty1 and Notch receptors (Seale et al. 2000; Shea et al. 2010; Mourikis and Tajbakhsh 2014). Upon activation, satellite cells downregulate quiescent genes while upregulating activation genes such as myoblast determination protein 1 (MyoD) and Myf5 (Comai and Tajbakhsh 2014; Yin et al. 2013). Myocytes further upregulate myogenin and MRF4, whereas differentiated multinucleated myofibers express various myosin heavy chain (MyHC) isoforms and a plethora of other differentiation-associated genes (Fig. 1) (Yin et al. 2013; Comai and Tajbakhsh 2014). The capacity to regenerate skeletal 


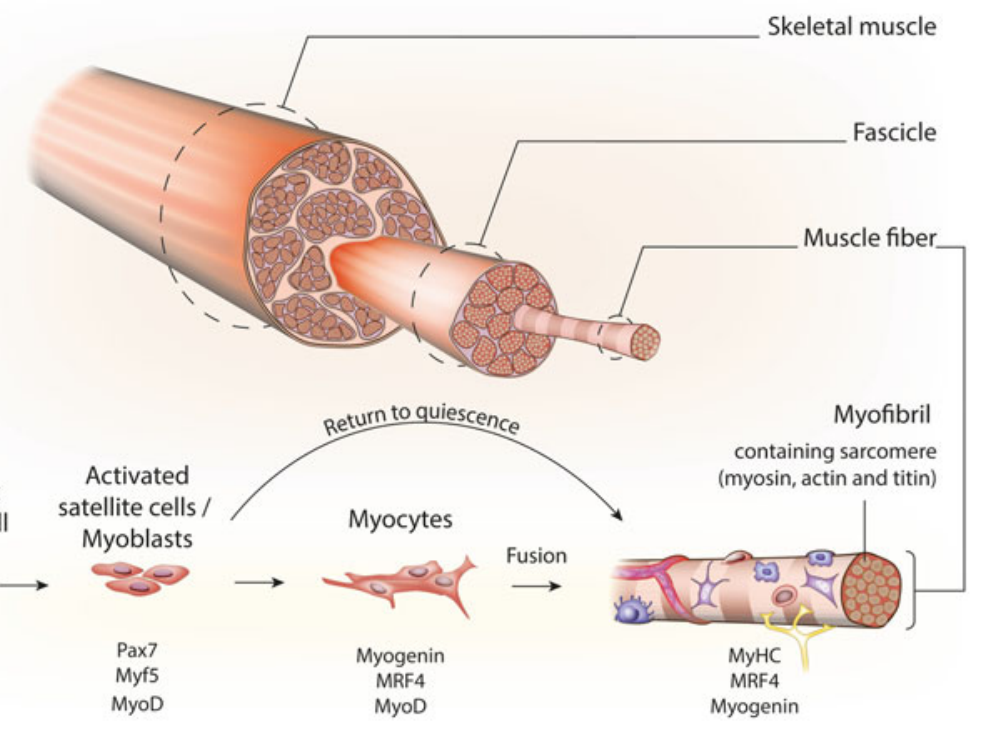

Endothelial cells

Immune cells Fibroblasts

Fig. 1 Skeletal muscle tissue is composed of multinucleated aligned muscle fibers as well as other muscle resident cells. Regeneration of skeletal muscle is a step-wise process initiated by activation of quiescent satellite cells, which give rise to highly proliferative myoblasts and fusion-competent myocytes that merge with each other or with damaged myofibers to regenerate the tissue. In addition to muscle cells, a milieu of resident cells in the form of fibroadipogenic progenitors, endothelial, white blood cells, and other cell types reside in skeletal muscle tissue, playing key roles in its homeostasis and regeneration

muscle is dependent on satellite cells, as their ablation completely abrogates skeletal muscle regeneration following injury (Murphy et al. 2011; Lepper et al. 2011; Sambasivan et al. 2011). In addition, mice lacking Pax7 exhibit growth retardation and small muscle mass size and typically die several weeks to months post birth (Seale et al. 2000; Oustanina et al. 2004). Recent research utilizing single cell sequencing methods have demonstrated that satellite cells display a large heterogeneity during homeostasis or regeneration, which is mirrored in their transcriptional expression profile (Yartseva et al. 2020; De Micheli et al. 2020).

Muscle regeneration is impaired in a wide array of pathological conditions such as traumatic muscle injury in the form of volumetric muscle loss (VML)(Corona et al. 2016), cancer-associated cachexia (Baracos et al. 2018), age-associated sarcopenia (Dennison et al. 2017), or muscular dystrophies (Motohashi et al. 2019). The latter group comprise a cluster of diseases characterized by progressive muscle wasting attributed to genetic mutations in genes that are critical for muscle function (Motohashi et al. 2019). Duchenne muscular dystrophy (DMD) is the most prevalent form of muscular dystrophy. It is an X-linked disorder that affects 
approximately 1 in 5000 boys worldwide, inflicting progressive muscle atrophy during early childhood, which eventually leads to complete muscle wasting and dysfunction (Yiu and Kornberg 2015). Patients with DMD experience death during the second or third decade of life as a result of cardiac or respiratory failure (Yiu and Kornberg 2015). The rapid muscle loss in DMD patients is attributed to a genetic mutation in dystrophin, an essential protein for healthy muscle function (Hoffman et al. 1987; Koenig et al. 1987). Dystrophin is expressed in differentiated myofibers, where it connects the sarcolemma to the extra cellular matrix (ECM) (Nowak and Davies 2004). More recently, it was reported to be expressed also in satellite cells, where it plays an essential role in asymmetric cell division during regeneration, and its absence significantly impairs satellite cell self-renewal (Dumont et al. 2015). As of today, there is a paucity of treatment for patients suffering from DMD and other muscle diseases such as VML, cachexia, and sarcopenia, rendering novel approaches in regenerative medicine and stem cell therapy attractive to treat these ailments as was shown for other somatic tissues (Mao and Mooney 2015; Blau and Daley 2019). For example, stem cell therapy via bone marrow engraftment is routinely used to treat blood disorders and more recently has been successfully used to treat skin and ocular diseases, raising hope for future stem cell therapies for skeletal muscle diseases (Blau and Daley 2019).

In this book chapter, we will present various stem cell-based and tissue engineering approaches to treat muscle diseases, with emphasis on treating patients who suffer from DMD or VML. We will further present past and contemporary challenges in utilizing stem cells or tissue engineering to treat muscle diseases and discuss innovative ways to resolve them. Lastly, we will highlight future research directions spearheaded by these technologies for skeletal muscle reparative therapy.

\section{Cell Replacement Therapy for the Treatment of Muscle Disorders}

Cell replacement therapy is an attractive approach to treat muscle-associated diseases characterized by cell death such as muscular dystrophies. The ultimate goal of this approach is to repair muscle damage via engraftment of healthy donor-derived cells into a disease-afflicted muscle tissue (Blau and Daley 2019). Candidate cell types proposed for this therapeutic approach include muscle stem or progenitor cells in the form of myoblasts (Partridge et al. 1989) or satellite cells (Montarras et al. 2005; Collins et al. 2005). Alternatively, other cell types can also be utilized via systemic delivery (Cossu et al. 2015; Sampaolesi et al. 2003; Torrente et al. 2004). The candidate cells can be healthy donor-derived allogeneic cells or autologous cells which are derived from the patient and therefore may require an ex vivo gene correction procedure (Fig. 2). To date, a majority of completed clinical trials have investigated the potential of myoblasts to treat skeletal muscle disorders, as these cells are relatively easy to isolate and expand in vitro, whereas very few studies have investigated the potential of other cell types to assist in muscle repair (Cossu et al. 2015; Torrente et al. 2007). In this section, we will briefly summarize historical and 
recent clinical trials conducted to treat muscle diseases by myoblast transplantation, focusing primarily on Duchenne muscular dystrophy (DMD) as a model. We will strive to introduce the main challenges and recent advancements in the field.

\subsection{Myoblast Transplantation for the Treatment of Duchenne Muscular Dystrophy}

Cell-based therapy as an approach to treat muscle diseases was first conceptualized in a 1978 seminal study by Partridge and colleagues (Partridge et al. 1978). Highlights of this pivotal study demonstrated that mouse donor-derived myoblasts could fuse with host cells upon intramuscular injection, leading to formation of hybrid myofibers composed of both recipient and donor cells (Partridge et al. 1978). Follow-up studies utilizing this approach established that injection of wild-type mouse myoblasts could form dystrophin-positive hybrid myofibers in dystrophic muscles of a mouse model for DMD (Partridge et al. 1989; Karpati et al. 1989), providing the conceptual framework to attempt myoblast transplantation trials in DMD patients during the 1990s (Law et al. 1991; Gussoni et al. 1992; Huard et al. 1992; Karpati et al. 1993; Tremblay et al. 1993a, b; Morandi et al. 1995; Mendell et al. 1995; Miller et al. 1997). Between 1990 and 1997, several clinical trials were conducted to assess myoblast transplantation as a potential therapy to treat DMD patients. Law and colleagues conducted the first clinical trial for myoblast transplantation in three DMD patients and detected dystrophin-positive myofibers in all of the patients' extensor digitorum brevis muscles 3 months post cell delivery (Law et al. 1990, 1991). In the notable 1992 Gussoni and colleagues clinical trial, donorderived cultured myoblasts from a father or sibling were injected into the tibialis anterior muscles of eight DMD patients, who were treated concomitantly with cyclosporine to counteract immune rejection of donor-derived cells (Gussoni et al. 1992). One month post transplantation, dystrophin mRNA from donor-derived cells was detected via PCR analysis in muscle samples from three patients; however it was deemed inconclusive whether dystrophin protein was successfully restored (Gussoni et al. 1992). Strikingly, re-analyses of muscle biopsies using fluorescence in situ hybridization (FISH) of six patients after intramuscular myoblast injection revealed fused and unfused donor nuclei in all examined muscles of the patients (Gussoni et al. 1997). In parallel and following the Gussoni study, additional clinical trials utilizing similar experimental designs were completed, however differed in the use of immunosuppressive drugs, injection strategies, and interpretation of outcome (Karpati et al. 1993; Huard et al. 1992; Tremblay et al. 1993a, b; Morandi et al. 1995; Mendell et al. 1995; Miller et al. 1997). An extensive comparison of these studies has been previously reported (Skuk 2004). Collectively, these studies confirmed that myoblast transplantation in humans is feasible and safe; however the clinical outcome was deemed deficient (Karpati et al. 1993; Gussoni et al. 1992; Huard et al. 1992; Tremblay et al. 1993a, b; Morandi et al. 1995; Mendell et al. 1995; Miller et al. 1997). Of note, a few studies reported slight beneficial effects on muscle strength following myoblast transplantation (Huard et al. 1992; Karpati et al. 1993; 


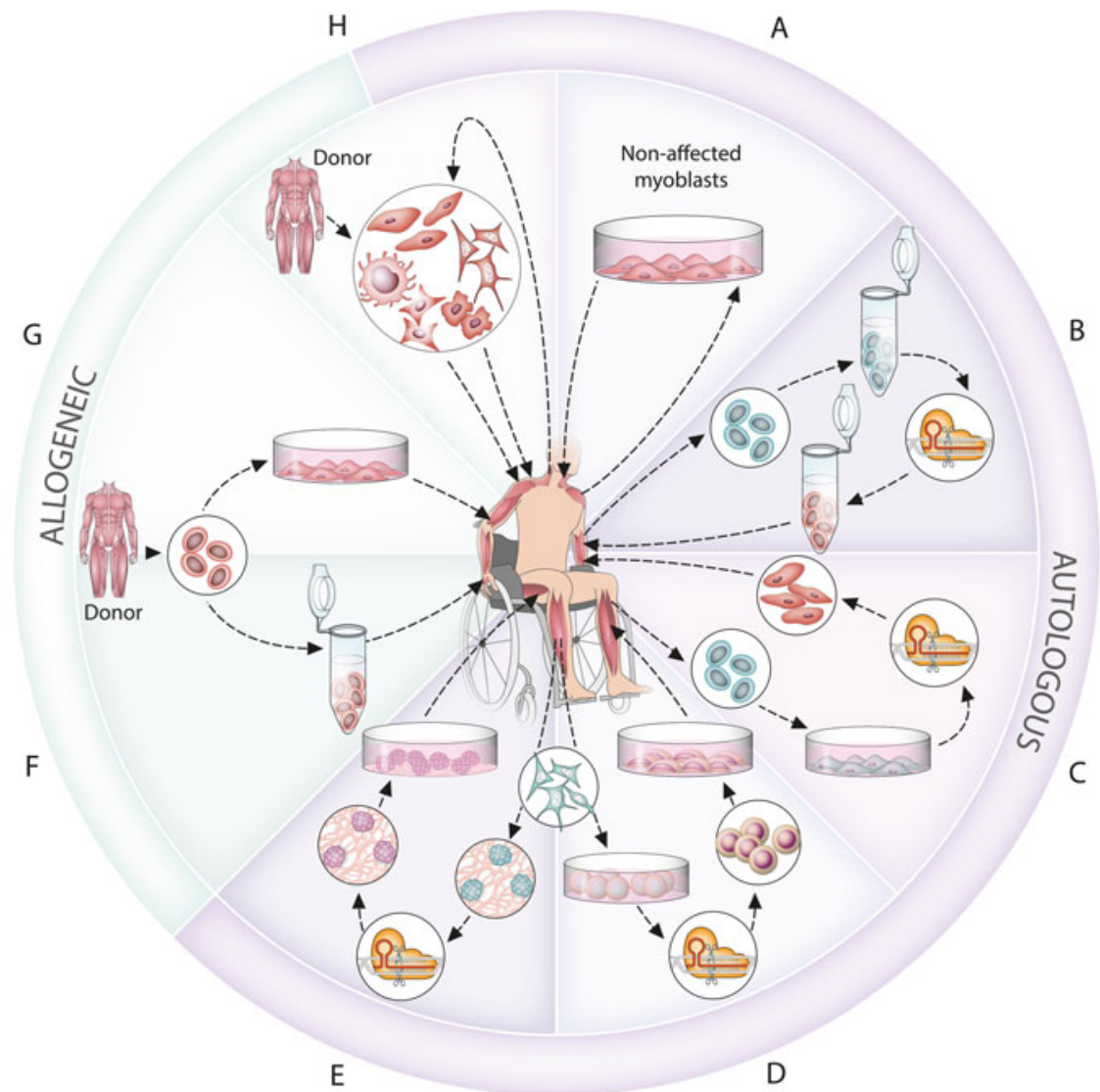

Before/after genetic correction:
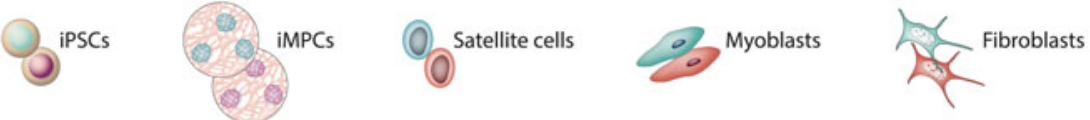

Myogenic precursors
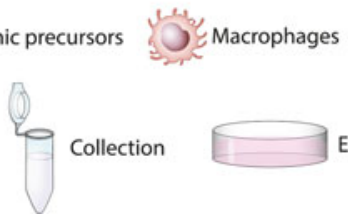

Expansion

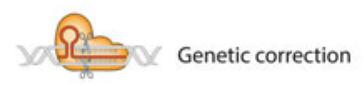

Fig. 2 Allogeneic and autologous cell replacement therapy approaches to treat muscular dystrophies. (a) Autologous myoblasts derived from healthy muscles are engrafted into dystrophic muscles. (b) Autologous satellite cells are genetically corrected during a transient ex vivo phase followed by engraftment. (c) Autologous myoblasts are transplanted back into muscles after expansion and ex vivo genetic correction phase. (d) Patient-derived induced pluripotent stem cells (iPSCs) are genetically corrected and differentiated into disease-free muscle precursors, which are engrafted back into the patient. (e) Patient-derived induced myogenic progenitor cells (iMPCs) are genetically corrected and engrafted back into the patient. (f) Engraftment of allogeneic 
Tremblay et al. 1993a; Law et al. 1991), however the majority of studies did not asses or report on functional improvement and failed to detect dystrophin-positive myofibers in patients (Morandi et al. 1995; Tremblay et al. 1993b; Mendell et al. 1995; Miller et al. 1997). Possible explanations for the unfavorable clinical outcome have been extensively discussed (Negroni et al. 2016; Skuk and Tremblay 2014), with attributing factors deemed to be (i) poor myoblast survival in host muscles; (ii) immune rejection against donor-derived myoblasts; (iii) failure of myoblasts to efficiently migrate from the injection site; and (iv) inability of cultured myoblasts to restore the muscle stem cell reservoir and elicit robust regeneration (Karpati et al. 1993; Wilschut et al. 2012; Maffioletti et al. 2014; Fan et al. 1996; Guerette et al. 1995; Qu et al. 1998). The rather disappointing human clinical trials conducted during the 1990s impeded subsequent clinical trials and their ramifications linger to some extent to this day.

\subsection{Addressing Translational Roadblocks for Myoblast Transplantation}

Despite the results of the unsuccessful clinical trials conducted during the $1990 \mathrm{~s}$, more recent studies performed on non-human primates have addressed a portion of the aforementioned challenges with the objective of improving myoblast transplantation (Table 1) (Skuk and Tremblay 2014).

One such approach is to modulate the type of immunosuppressive drugs administered to counteract immunological responses in patients. Administration of immunosuppressive drugs for successful allogeneic myoblast transplantation has been rigorously demonstrated in both rodent and non-human primate studies (Kinoshita et al. 1994; Pavlath et al. 1994; Kinoshita et al. 1996). Historically, cyclosporine was the preferred immunosuppressant used in the majority of early human trials (Gussoni et al. 1992; Morandi et al. 1995; Mendell et al. 1995; Miller et al. 1997). However, more recent studies have shown that cyclosporine impedes myoblast fusion and differentiation (Hong et al. 2002). Alternative treatment of non-human primates with the immunosuppressant tacrolimus have led to long-term engraftment of allogeneic myoblasts (Kinoshita et al. 1996), resulting in tacrolimus replacing cyclosporine as the immunosuppressant of choice.

Inflicting localized muscle damage by irradiation, mechanical pressure, freezing, or chemicals is a commonly used method to enhance muscle stem and progenitor cell-engraftment in rodent transplantation models (Mueller and Bloch 2019; Hardy et al. 2016). Moreover, studies performed in non-human primates reported

Fig. 2 (continued) satellite cells derived from a healthy donor into dystrophic muscles. (g) Engraftment of allogeneic myoblasts derived from a healthy donor into dystrophic muscles. (h) Co-engraftment of muscle cells with other cell types involved in muscle repair could enhance muscle regeneration and remedy dystrophic symptoms 
Table 1 Select studies that have investigated myoblast transplantation in non-human primates

\begin{tabular}{|c|c|c|}
\hline Study/topic & Primary experiments & Results/findings \\
\hline $\begin{array}{l}\text { Kinoshita et al. } \\
\text { (1996) } \\
\text { Immune system }\end{array}$ & $\begin{array}{l}\text { Intramuscular injection of allogeneic } \\
\text { myoblasts }(\text { LacZ) into NHPs treated } \\
\text { with tacrolimus or without } \\
\text { immunosuppressant }\end{array}$ & $\begin{array}{l}\text { Lymphocyte infiltration and increase } \\
\text { in cytokines } 7 \text { days post MT in the } \\
\text { absence of tacrolimus. } B-\text { Gal- } \\
\text { positive fibers were not detected } \\
4 \text { weeks post MT } \\
\text { Detection of } \text { B-Gal-positive fibers } 1 \text {, } \\
4 \text {, and } 12 \text { weeks post MT with } \\
\text { significant reduced lymphocyte } \\
\text { infiltration and cytokines with } \\
\text { tacrolimus compared to no } \\
\text { tacrolimus administration }\end{array}$ \\
\hline $\begin{array}{l}\text { Skuk et al. } \\
(1999) \\
\text { Notexin }\end{array}$ & $\begin{array}{l}\text { Allogeneic myoblasts }(\operatorname{LacZ}) \text { were } \\
\text { injected with or without notexin and } \\
\text { varying cell number }\left(4 \times 10^{6},\right. \\
\left.8 \times 10^{6}, 24 \times 10^{6}\right) \text { with } 35-40 \\
\text { injections (separated by } 1 \mathrm{~mm})\end{array}$ & $\begin{array}{l}8 \times 10^{6} \text { led to most } \beta \text {-Gal-positive } \\
\text { fibers } 4 \text { weeks post MT } \\
\text { Injection of } 8 \times 10^{6} \text { myoblasts } \\
\text { suspended in notexin led to a } 50 \% \\
\text { increase of } \beta \text {-Gal fibers } 4 \text { weeks post } \\
\text { MT }\end{array}$ \\
\hline $\begin{array}{l}\text { Skuk et al. } \\
(2002) \\
\text { Injection, } \\
\text { immune system }\end{array}$ & $\begin{array}{l}\text { Injection of allogeneic myoblasts } \\
\text { (LacZ) with varying inter-injection } \\
\text { distances }(1 \mathrm{~mm}, 1-1.5 \mathrm{~mm}, 2 \mathrm{~mm}) \\
\text { and different concentrations of } \\
\text { tacrolimus alone or combined with } \\
\text { mycophenolate mofetil }\end{array}$ & $\begin{array}{l}\text { Detection of } 25-67 \% \text { B-Gal-positive } \\
\text { fibers } 1 \text { month post MT (injection } \\
\text { distance } 1 \mathrm{~mm} \text { ) } \\
\text { Combination of tacrolimus with } \\
\text { mycophenolate mofetil enabled a } \\
\text { decreased dosage of tacrolimus }\end{array}$ \\
\hline $\begin{array}{l}\text { Lafreniere et al. } \\
(2009) \\
\text { Growth factors }\end{array}$ & $\begin{array}{l}\text { Intramuscular injection of allogeneic } \\
\text { myoblasts }(\text { LacZ) combined either } \\
\text { with bFGF or IGF-1 }\end{array}$ & $\begin{array}{l}\text { Growth factors increased myoblast } \\
\text { migration } 60 \mathrm{~h} \text { post MT } \\
\text { No significant differences detected } \\
\text { in } ß \text {-Gal-positive fiber formation } \\
4 \text { weeks post MT }\end{array}$ \\
\hline $\begin{array}{l}\text { Skuk et al. } \\
(2011) \\
\text { Migration }\end{array}$ & $\begin{array}{l}\text { Allogeneic myoblasts }(\text { LacZ) were } \\
\text { subcutaneously injected above a } \\
\text { needle-damaged muscle }\end{array}$ & $\begin{array}{l}\text { Detection of migrated myoblasts } \\
\text { that formed } \beta \text {-Gal-positive } \\
\text { myofibers within a damaged muscle } \\
\text { along the needle trajectories } 1 \mathrm{~cm} \\
\text { apart from injected site, } 1 \text { month } \\
\text { post subcutaneous MT }\end{array}$ \\
\hline $\begin{array}{l}\text { Skuk et al. } \\
\text { (2013) } \\
\text { Electroporation }\end{array}$ & $\begin{array}{l}\text { A } 1 \mathrm{~mm}^{2} \text { muscle area was } \\
\text { electroporated with } 3 \text { pulses of } \\
400 \mathrm{~V} / \mathrm{cm} \text { before allogeneic } \\
\text { myoblasts ( } \text { LacZ) were injected } \\
\text { either in a matrix consisting of } 25 \\
\text { injections or radial injection }\end{array}$ & 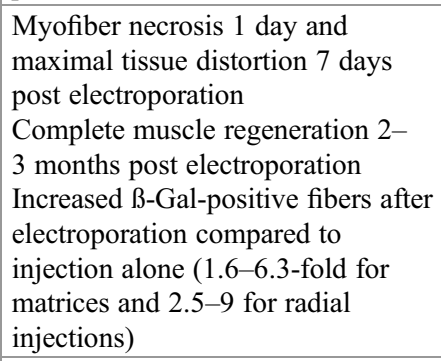 \\
\hline $\begin{array}{l}\text { Skuk et al. } \\
(2014) \\
\text { Injection }\end{array}$ & $\begin{array}{l}\text { Intramuscular injection of allogeneic } \\
\text { myoblasts }(\text { LacZ) with varying } \\
\text { needle sizes }(27 \mathrm{G}, 22 \mathrm{G}, 18 \mathrm{G}) \\
\text { amount of cells }\left(10^{2}, 10^{3}, 10^{4}, 10^{5}\right. \\
10^{6} / \mathrm{cm} \text { injection trajectory, and }\end{array}$ & $\begin{array}{l}\text { Muscle sections revealed that an } \\
\text { injection of at least } 100,000 \text { cells } / \mathrm{cm} \\
\text { in } 1 \mu \mathrm{l} / \mathrm{cm} \text { trajectory with a } 27 \mathrm{G} \\
\text { generated highest amounts of } \beta \text {-Gal- }\end{array}$ \\
\hline
\end{tabular}


Table 1 (continued)

\begin{tabular}{|c|c|c|}
\hline Study/topic & Primary experiments & Results/findings \\
\hline & $\begin{array}{l}\text { injected volume ( } 1 \mathrm{ul}, 5 \mathrm{ul}, 25 \mathrm{ul} / \mathrm{cm} \\
\text { injection trajectory) }\end{array}$ & $\begin{array}{l}\text { positive fibers } 1 \text { or } 2 \text { months post } \\
\text { MT }\end{array}$ \\
\hline $\begin{array}{l}\text { Skuk and } \\
\text { Tremblay } \\
\text { (2017a) } \\
\text { Cell death }\end{array}$ & $\begin{array}{l}\text { Injection of radiolabeled autologous } \\
\text { or allogeneic myoblasts (with or } \\
\text { without } \text { LacZ) into NHPs (with or } \\
\text { without immunosuppressant) }\end{array}$ & $\begin{array}{l}\text { Majority of cells ( } 80-92 \%) \text { died } \\
\text { within the first } 7 \text { days regardless of } \\
\text { whether 1), they were autologous or } \\
\text { allogeneic or } 2 \text { ) if the recipient NHP } \\
\text { received an immunosuppressant } \\
\text { drug } \\
\text { No further cell death } 3 \text { weeks post } \\
\text { injection }\end{array}$ \\
\hline $\begin{array}{l}\text { Skuk and } \\
\text { Tremblay } \\
\text { (2017b) } \\
\text { Engraftment }\end{array}$ & $\begin{array}{l}\text { Intramuscular injection of myoblasts } \\
\text { ( } L a c Z \text { ) and subsequent assessment } \\
\text { of cell engraftment (after } 1 \mathrm{~h}, 1 \text { day, } \\
3 \text { days, } 7 \text { days and } 3 \text { weeks) }\end{array}$ & $\begin{array}{l}\text { Detection of majority of myoblasts } \\
\text { in between the muscle bundle and } \\
\text { the perimysium } 1 \mathrm{~h} \text { and } 1 \text { day post } \\
\text { MT } \\
\text { Detection of } ß-\text {-Gal-positive } \\
\text { myofibers along the injection } \\
\text { trajectories } 3 \text { weeks post MT }\end{array}$ \\
\hline
\end{tabular}

NHPs non-human primates, MT myoblast transplantation, $\beta$-Gal $\beta$-galactosidase

partial increase in engrafted myofibers when myoblasts were transplanted into injured muscle tissue by notexin or electroporation (Skuk et al. 1999, 2000, 2013). However, inflicting muscle damage prior to transplantation is both ethically and technically challenging to translate to human patients due to potential adverse side effects (Skuk et al. 2002). Therefore, myoblast engraftment has been investigated without inducing muscle damage with the exception of localized insult caused by the injection needle (Skuk et al. 2002). Of note, the non-human primate studies demonstrated migration of myoblasts toward damaged myofibers and engraftment at the injection site (Skuk et al. 2002, 2011). Based on these observations, it was suggested that in the absence of extensive muscle damage, multiple close proximity injections will be required to achieve substantial engraftment of transplanted myoblasts (Skuk et al. 2002, 2006b, 2011). This hypothesis has led to two clinical trials involving human patients that utilized several novel strategies (Table 2) (Skuk et al. 2004, 2006a, 2007, 2010; Skuk and Tremblay 2016). In the first study, nine DMD patients were injected with high-density allogeneic myoblasts in the tibialis anterior muscle while being treated in parallel with the immunosuppressant tacrolimus (Skuk et al. 2006a). In contrast to previous trials, between $3.5 \%$ and $26 \%$ dystrophin-positive myofibers were detected in sampled muscles, while patients did not develop a major immune reaction (Skuk et al. 2006a). In a separate study, an entire thenar eminence muscle was injected with myoblasts to assess the safety of high-density injections (Skuk et al. 2007). The procedure was well tolerated by the patient without severe adverse effects or complications. The patient further showed an increase in force generation in comparison to pre-transplantation (Skuk et al. 2007). Remarkably, donor-derived muscle cells remained at the engraftment site 18 months post transplantation, suggesting a long-term engraftment potential (Skuk et al. 2007). 
Table 2 Myoblast transplantation trials in DMD and oculopharyngeal muscular dystrophy (OPMD) patients between 2004 and 2014

\begin{tabular}{|c|c|c|c|c|}
\hline Study & $\begin{array}{l}\text { Patient cohort } \\
\text { (Number/age } \\
\text { demographic) }\end{array}$ & Donor & $\begin{array}{l}\text { Study protocol: } \\
\text { (a) Quantity of } \\
\text { injected myoblasts/ } \\
\text { muscle type } \\
\text { (b) Injection method } \\
\text { (c) } \\
\text { Immunosuppressive } \\
\text { drug } \\
\text { (d) Blinded vs. non- } \\
\text { blinded }\end{array}$ & $\begin{array}{l}\text { Results: } \\
\text { (a) Molecular } \\
\text { findings } \\
\text { (b) Functional } \\
\text { findings }\end{array}$ \\
\hline $\begin{array}{l}\text { Skuk et al. } \\
(2004, \\
2006 a, \\
2010), \text { Skuk } \\
\text { and } \\
\text { Tremblay } \\
(2016)\end{array}$ & $\begin{array}{l}9 \text { patients/age: } \\
8-17 \text { years }\end{array}$ & $\begin{array}{l}\text { Father or } \\
\text { mother }\end{array}$ & $\begin{array}{l}\text { (a) } 18.5-30 \times 10^{6} \\
\text { into TA } \\
\text { (b) } 0.25 \mathrm{~cm}^{3} \text { with } 25 \\
\text { injections } 1-2 \mathrm{~mm} \\
\text { apart with } 25-\text { or } 22- \\
\text { gauge needle; or } \\
1 \mathrm{~cm}^{3} \text { with } 25 \text { or } 100 \\
\text { injections } 1-2 \mathrm{~mm} \\
\text { apart with } 27-, 26-\text { or } \\
25 \text {-gauge needle } \\
\text { (c) Tacrolimus } \\
\text { (d) Non-blinded }\end{array}$ & $\begin{array}{l}\text { (a) Dystrophin- } \\
\text { positive myofibers } \\
\text { detected in TA of } \\
8 \text { patients (3.5- } \\
26 \% \text { ), specific } \\
\text { antibody staining } \\
\text { showed that } \\
\text { dystrophin-positive } \\
\text { myofibers were } \\
\text { donor-derived in } 7 \\
\text { patients. Detection } \\
\text { of two groups of } \\
\text { dystrophin-positive } \\
\text { myofibers: Large } \\
\text { fibers derived from } \\
\text { fusion with existing } \\
\text { fibers and small } \\
\text { fibers derived from } \\
\text { fusion of donor cells } \\
\text { alone, donor mRNA } \\
\text { was detected in } 9 \\
\text { patients, detection of } \\
\text { mononuclear donor- } \\
\text { derived myoblasts in } \\
\text { the satellite cell } \\
\text { niche } 4 \text { weeks post } \\
\text { MT, detection of } \\
\text { antibodies against } \\
\text { donor cells in two } \\
\text { patients (already } \\
\text { detected pre- } \\
\text { transplantation) } \\
\text { (b) Not assessed }\end{array}$ \\
\hline $\begin{array}{l}\text { Skuk et al. } \\
\text { (2007) }\end{array}$ & $\begin{array}{l}1 \text { patient/age: } \\
26 \text { years }\end{array}$ & Father & $\begin{array}{l}\text { (a) } 275 \times 10^{6} \text { into } \\
\text { TE (whole muscle), } \\
538 \times 10^{6} \text { into BB } \\
\text { (whole muscle), } \\
135 \times 10^{6} \text { into G } \\
\text { (b) High-density } \\
\text { injections (separated }\end{array}$ & $\begin{array}{l}\text { (a) Dystrophin- } \\
\text { positive myofibers } \\
\text { detected in G } \\
(27.5 \% 1 \text { month, } \\
34.5 \% 18 \text { months } \\
\text { post MT), massive } \\
\text { fibrosis and adipose }\end{array}$ \\
\hline
\end{tabular}


Table 2 (continued)

\begin{tabular}{|c|c|c|c|c|}
\hline \multirow[t]{2}{*}{ Study } & $\begin{array}{l}\text { Patient cohort } \\
\text { (Number/age } \\
\text { demographic) }\end{array}$ & Donor & $\begin{array}{l}\text { Study protocol: } \\
\text { (a) Quantity of } \\
\text { injected myoblasts/ } \\
\text { muscle type } \\
\text { (b) Injection method } \\
\text { (c) } \\
\text { Immunosuppressive } \\
\text { drug } \\
\text { (d) Blinded vs. non- } \\
\text { blinded }\end{array}$ & $\begin{array}{l}\text { Results: } \\
\text { (a) Molecular } \\
\text { findings } \\
\text { (b) Functional } \\
\text { findings }\end{array}$ \\
\hline & & & $\begin{array}{l}\text { by } 1 \mathrm{~mm} \text { ) with } 27-\text { or } \\
26 \text {-gauge needle } \\
\text { (c) Tacrolimus } \\
\text { (d) Non-blinded }\end{array}$ & $\begin{array}{l}\text { tissue in BB and } \\
\text { only } 2 \text { dystrophin- } \\
\text { positive myofibers } \\
\text { detected, detection } \\
\text { of donor-derived } \\
\text { mRNA in BB and G } \\
\text { (b) Increased } \\
\text { strength of first } \\
\text { metacarpal flexion } \\
\text { post MT ( } 70 \% \\
1 \text { month, } 100 \% \\
2 \text { months, } 50 \% \\
15 \text { months post MT } \\
\text { compared to pre- } \\
\text { transplantation) }\end{array}$ \\
\hline $\begin{array}{l}\text { Perie et al. } \\
(2014)\end{array}$ & $\begin{array}{l}12 \text { patients/age: } \\
18-75 \text { years }\end{array}$ & $\begin{array}{l}\text { Cells } \\
\text { derived } \\
\text { from } \\
\text { patient's } \\
\text { unaffected } \\
\text { Q or SCM }\end{array}$ & $\begin{array}{l}\text { (a) } 178 \times 10^{6} \\
\text { (median) into } \\
\text { pharyngeal muscles } \\
\text { (b) Myotomy before } \\
\text { injection, } 12 \\
\text { injections, } 10 \mathrm{~cm}^{2} \\
\text { (c) Not administered } \\
\text { (d) Non-blinded }\end{array}$ & $\begin{array}{l}\text { (a) Myoblast } \\
\text { engraftment was not } \\
\text { assessed } \\
\text { (b) Upper } \\
\text { esophageal } \\
\text { sphincter function } \\
\text { improved in } \\
8 \text { patients } 2 \text { years } \\
\text { post MT, increased } \\
\text { quality of life score } \\
\text { in } 12 \text { patients, no } \\
\text { degradation in } \\
\text { swallowing function } \\
\text { in } 10 \text { patients }\end{array}$ \\
\hline
\end{tabular}

$M T$ myoblast transplantation, $T A$ tibialis anterior, $B B$ biceps brachii, $T E$ thenar eminence, $G$ gastrocnemius, $Q$ quadriceps, $S C M$ sternocleidomastoid

Currently, safety and functional outcome of myoblast transplantation throughout extensor carpi radialis muscles of DMD patients are being tested in a clinical phase I/II trial (NCT02196467).

Inflicting confined muscle damage to provide a niche for cell engraftment carries potential significant health risks for human DMD patients. However in the context of blood diseases, bone marrow ablation by irradiation prior to blood stem cell infusion is a well-established treatment procedure (Blau and Daley 2019). Therefore, it may 
be of interest to assess if localized ablation of muscle cells by irradiation followed by high-proximity injection of myoblasts into dystrophic muscles could elicit migration beyond the injection site, achieving robust regeneration. Given evident experimental success in animal models, there is potential to adapt this approach in human patients during future trials.

\subsection{Clinical Procedures Involving Autologous Myoblast Transplantation}

To date, only allogeneic myoblasts with or without immunosuppressive drug administration have been used to treat human DMD patients (Gussoni et al. 1992; Huard et al. 1992; Karpati et al. 1993; Tremblay et al. 1993a, b; Morandi et al. 1995; Mendell et al. 1995; Miller et al. 1997; Skuk et al. 2006a, 2007; Law et al. 1991). In contrast, autologous myoblast transplantation has been successfully employed in animal models and several clinical trials for urinary incontinence (Mitterberger et al. 2008; Sebe et al. 2011; Blaganje and Lukanovic 2012; Stangel-Wojcikiewicz et al. 2014; Jankowski et al. 2018; Eberli et al. 2012), fecal incontinence (Frudinger et al. 2015; Romaniszyn et al. 2015; Boyer et al. 2018; Bisson et al. 2015), as well as oculopharyngeal muscular dystrophy (OPMD)(Perie et al. 2014). For further reading on these procedures, we refer the readers to recently published reviews (Hillary et al. 2020; Simillis et al. 2019; Trebol et al. 2018). During these trials, immunosuppressive drugs were not administered, thereby simplifying the procedure and reducing the risk of adverse health complications. Notably, a recent success in utilizing autologous myoblasts to treat OPMD has been reported (Perie et al. 2014) (Fig. 2a). This type of muscular dystrophy is characterized by progressive degradation and weakening of the ocular and pharyngeal muscles, leading to ptosis and dysphagia (Brais et al. 1998). OPMD is caused by an autosomal gene mutation that results in amplification of GCG nucleotides in the PABPN1 gene (Brais et al. 1998). Currently, symptoms are treated by a cricopharyngeal myotomy; however, the long-term benefits of this procedure remain controversial (Duranceau et al. 1980; Perie et al. 2014). In rare disparity to other muscular dystrophies, not all muscles of OPMD patients are affected (Perie et al. 2006). Comparisons of myoblasts derived from affected and non-affected muscles of OPMD patients have shown that the latter exhibited higher proliferation and myogenic regeneration capacity (Perie et al. 2006). This observation was followed by a non-placebo controlled clinical trial that tested myoblast transplantation in OPMD patients (Perie et al. 2014). Autologous myoblasts derived from unaffected quadriceps or sternocleidomastoid muscles were injected into pharyngeal muscles of 12 OPMD patients after myotomy (Perie et al. 2014). Remarkably, this procedure successfully ceased further degradation of pharyngeal muscles in patients 2 years post-surgery in addition to improving quality of life criteria factors in all patients (Perie et al. 2014). To date, this study is one of a handful to demonstrate a beneficial therapeutic outcome of myoblast transplantation. In the future, it will be central to corroborate these promising results with additional experiments that include placebo-controlled groups and patients subjected to 
myoblast engraftment with or without prior myotomy. Autologous myoblast transplantation from non-afflicted muscles may be applicable to other muscular dystrophies such as facioscapulohumeral muscular dystrophy and could provide a beneficial method to treat muscle diseases (Fig. 2a) (Vilquin et al. 2005).

Autologous myoblasts expressing a shorter but functional micro-dystrophin have been successfully transplanted into non-human primates (Quenneville et al. 2007). However, autologous myoblast transplantation in human cell engraftment patients has not been reported, although rapid advances in genome engineering techniques may pave way for investigating such an approach in the future (Doudna and Charpentier 2014; Briggs and Morgan 2013; Min et al. 2019) (Fig. 2c). Harnessing the CRISPR-Cas9 genome editing system to correct the dystrophin mutation in the $D m d^{m d x}$ mouse model was recently reported by several seminal studies, demonstrating functional restoration of the dystrophin protein in myofibers (Long et al. 2016; Tabebordbar et al. 2016; Nelson et al. 2016) and potentially muscle stem cells (Tabebordbar et al. 2016; Nance et al. 2019). $D m d^{m d x}$ myoblasts were also genetically corrected in vitro using CRISPR-Cas9 and reported to give rise to dystrophinpositive fibers upon transplantation (Zhu et al. 2017; Matre et al. 2019; Ousterout et al. 2015). With respect to correction of human dystrophin mutations, Young and colleagues recently developed a strategy to fix a mutational hot spot by a CRISPRCas9 exon skipping-based approach, which encompasses approximately $60 \%$ of all DMD patient mutations (Young et al. 2016). In this elegant study, DMD patientderived fibroblasts were first reprogrammed into induced pluripotent stem cells (iPSCs) (Young et al. 2016). Correction of the dystrophin mutation was performed at the pluripotent state, followed by directed differentiation of the iPSCs into dystrophin-positive muscle cells (Young et al. 2016). By taking a similar experimental approach, myoblasts could be expanded from patients, corrected by genome engineering, and then transplanted back into patients (Fig. 2c). Similarly, it might be feasible to correct satellite cells during a short-lived ex vivo phase followed by engraftment (Fig. 2b). However, it is important to note that restoration of dystrophin expression by transplantation of autologous myoblasts carries the risk of eliciting an immune reaction against a "foreign" protein, necessitating potential use of immunosuppressants (Selvaraj et al. 2019).

\subsection{Further Considerations for Improvement of Myoblast Transplantation}

The overarching goal of cell replacement therapy for muscle diseases is to establish the long-term regeneration potential of transplanted cells, which requires contribution to the muscle stem cell reservoir. However, it remains unclear whether myoblasts carry an efficient propensity to induce such long-term regeneration capacity, albeit some studies indicate feasibility (Yao and Kurachi 1993; Heslop et al. 2001; Skuk et al. 2010). Notably, a clinical trial in DMD human patients detected a 
presence of donor-derived mononuclear cells in muscles, suggestive of contribution to the satellite cell niche (Skuk et al. 2006a, 2010). In support of this observation, dystrophin-positive myofibers have been detected in DMD patients 18 months post myoblast transplantatio n (Skuk et al. 2007). Similar observations have been documented in myoblast transplantation trials for the treatment of fecal or urinary incontinences (Jankowski et al. 2018; Frudinger et al. 2015; Romaniszyn et al. 2015), although cell engraftment was not thoroughly assessed (Jankowski et al. 2018; Frudinger et al. 2015).

Whereas the contribution of transplanted myoblasts to long-term muscle regeneration has yet to be fully elucidated, satellite cells exhibit a high regeneration capacity and can efficiently contribute to the muscle stem cell reservoir (Montarras et al. 2005; Collins et al. 2005; Cerletti et al. 2008). In the next sections, we will discuss advances in direct isolation and transplantation of satellite cells or engraftment after an ex vivo propagation phase. We will further discuss new techniques that could allow partial retainment of satellite-cell characteristics in vitro. These novel approaches could pave the way for utilizing satellite cells instead of myoblasts as the preferred cells for engraftment in clinical settings.

\section{Engraftment of Freshly Isolated Satellite Cells for Muscle Regeneration}

Despite the immense therapeutic potential of utilizing satellite cells to treat muscleassociated diseases, unresolved challenges have limited their use in cell-based therapies. Shortly after QSCs are mechanically and enzymatically dissociated from muscle fibers they undergo activation, a process characterized by rapid upregulation of myoblast-associated genes and commitment to a myogenic differentiation program (Machado et al. 2017; Pietrosemoli et al. 2017; van Velthoven et al. 2017). This renders the therapeutic use of satellite cells for muscle transplantation challenging, as their engraftment potential decreases once expanded in vitro (Montarras et al. 2005; Collins et al. 2005; Quarta et al. 2016; Xu et al. 2015b; Sacco et al. 2008). To overcome this challenge, satellite cells can be isolated by a fluorescence-activated cell sorting (FACS) machine and injected directly into muscles. A manifold of reports have shown that by utilizing this approach, injected mouse or human satellite cells could significantly contribute to muscle regeneration (Montarras et al. 2005; Quarta et al. 2016; Xu et al. 2015b; Sherwood et al. 2004; Kuang et al. 2007). Moreover, engrafted satellite cells can enter their respective niche under the basal lamina (Xu et al. 2015b; Kuang et al. 2007), sustain multiple rounds of injuryinduced regeneration (Collins et al. 2005; Rocheteau et al. 2012), and in addition be subjected to serial transplantation for up to seven rounds in mice (Rocheteau et al. 2012). Furthermore, engrafted myofiber fragments containing adjoined satellite cells can promote robust muscle regeneration and repair (Collins et al. 2005; Hall et al. 2010; Marg et al. 2014). Strikingly, a seminal study reported that a single satellite cell can regenerate a significant segment of skeletal muscle tissue in mice (Sacco et al. 2008). 
Satellite cells comprise a subset of the mononucleated cell fraction in skeletal muscle tissue (Dell'Orso et al. 2019; Giordani et al. 2019; Rubenstein et al. 2020). This necessitates usage of genetic reporters or identification of surface markers for prospective isolation and transplantation of homogenous cell populations. Genetic reporters for Pax3 and Pax7 have been successfully employed to isolate murine satellite cells (Fig. 3) (Bosnakovski et al. 2008; Sambasivan et al. 2009; Montarras et al. 2005); however isolation of humans satellite cells using this approach is not feasible. Alternatively, surface markers can be applied to isolate satellite cells by a FACS machine. To this end, several murine-positive surface markers have been identified including CD34, Cxcr4/ITGB1, Vcam1, and alpha-7 integrin (Sherwood et al. 2004; Liu et al. 2013; Beauchamp et al. 2000; Fukada et al. 2004; Cerletti et al. 2008; Kuang et al. 2007). Similarly, several positive surface markers have been successfully identified that allow prospective isolation of human muscle stem cells including CD56/CD29 (Xu et al. 2015b), CD56/CD29/CXCR4 (Garcia et al. 2018), CD56/ITGA7 (Castiglioni et al. 2014), CD82/CD318 (Uezumi et al. 2016), and CD82 (Alexander et al. 2016). These efforts to identify, isolate, and characterize muscle stem cells have provided a plethora of new knowledge in respect to transplantation methods and assessment of satellite cell regenerative potential. For example, studies have reported that freshly isolated human satellite cells efficiently fuse with myofibers of immunodeficient or dystrophic mice (Alexander et al. 2016; Uezumi et al. 2016; Xu et al. 2015b). Furthermore, 5 weeks post muscle transplantation, human spectrin, and dystrophin-positive myofibers were detected in mouse muscles, and putative human satellite cells were identified under the basal lamina, suggesting contribution to the satellite cell niche (Xu et al. 2015b). Remarkably, engrafted human satellite cells were also shown to sustain two rounds of serial transplantation in mice (Garcia et al. 2018).

Akin to myoblasts, satellite cells cannot be delivered systemically and do not efficiently migrate across the muscle beyond the injection area. Due to this limitation, Garcia and colleagues opted to transplant satellite cells across multiple injection sites within the same muscle, demonstrating that as few as 2000 human satellite cells have led to the formation of approximately 155 human spectrin-positive myofibers (Garcia et al. 2018). Additionally, they detected increased quantities of human donor-derived $\mathrm{Pax} 7^{+}$cells around the injection sites (Garcia et al. 2018). The authors suggest that satellite cell-delivery utilizing multiple injection sites is essential and more important than the number of injected cells (Garcia et al. 2018). This observation is reminiscent of the enhanced myoblast engraftment potential seen in human patients transplanted using close-proximity injections (Skuk et al. 2006a).

An additional limiting factor of using satellite cells for regenerative medicine purposes is low extraction yield of cells from allogeneic muscle donors. An alternative source for obtaining high quantities of satellite cells could be cadavers, as quiescent satellite cells have been shown to maintain their regenerative capacity in muscles for up to 17 days post mortem (Latil et al. 2012) or following hypothermic storage (Marg et al. 2014). These intriguing observations suggest that muscles of deceased individuals could potentially be used for satellite cell extraction, similar to donor-derived human organs purposed for transplantation. 
Although pure myogenic stem cells can be isolated from muscles via a suite of surface markers, no clinical trials to date have investigated the potential of freshly isolated human satellite cells to remedy muscle-associated diseases in humans. Taking into consideration evidence from transplantation experiments of human myoblasts and satellite cells, one can cautiously postulate that engraftment of satellite cells into dystrophic muscles of DMD patients will be superior to that of myoblasts. To test this hypothesis, it will be of interest to assess the capacity of freshly isolated human satellite cells and myoblasts to engraft into muscles of nonhuman primates, similar to reports that have assessed myoblast engraftment in nonhuman primates (Skuk et al. 2011; Skuk and Tremblay 2017a; Skuk et al. 2002). Skeletal muscle of primates may provide a more receptive host niche for engraftment of human muscle stem cells due to species similarity and size. Successes in generating human-primate hybrid muscles will provide salient insights into the propensity of freshly isolated human satellite cells to engraft, migrate, and regenerate muscles, in addition to bearing implications for adapting this technique in humans.

Notable challenges of satellite cell utilization in cell therapy include low cell extraction yield, poor cell migration, and an inability to deliver the cells systemically. In consideration of these limitations, it might be beneficial to exploit satellite cells in clinical settings for muscles that are of small size and in conjunction with closeproximity injections. For example, localized satellite cell transplantation into finger muscles of DMD patients might curtail muscle degeneration and thus provide substantial improvement in life quality measures, despite not treating the underlying cause of mortality (Fig. 2f).

Besides allogeneic satellite cells, autologous satellite cells could be isolated from a patient's biopsy followed by correction of the dystrophin gene and subsequent engraftment into dystrophic muscles (Fig. 2b). While it was reported that quiescent satellite cells cannot be transduced by adeno-associated viral (AAV) vectors (Arnett et al. 2014), recent studies suggest that muscle stem cells can be targeted and gene corrected in vivo using AAV serotype 9 (Tabebordbar et al. 2016; Goldstein et al. 2019; Nance et al. 2019). However, in vitro correction of satellite cells remains challenging, mainly due to the conversion of satellite cells into myoblasts shortly after isolation and culture.

In summary, obtaining sufficient quantities of satellite cells for muscle injections still remains a formidable challenge. This hurdle highlights the need for generating expandable myogenic stem cells apt for regenerative medicine purposes. In the next section, we will introduce alternative methods for generating copious amounts of expandable muscle precursor cells in vitro.

\section{Generation of Myogenic Precursors from Pluripotent Stem Cells}

An alternative cellular source for production of myogenic precursors are pluripotent stem cells (PSCs) in the form of blastocyst-derived embryonic stem cells (ESCs) or somatic cell-derived induced pluripotent stem cells (iPSCs) (Selvaraj et al. 2019; 
Magli and Perlingeiro 2017). An advantage for using PSCs is their ability to expand indefinitely in vitro, thus enabling the generation of high quantities of muscle precursors (Selvaraj et al. 2019). The following section will briefly recount recent works which reported on successful differentiation of PSCs into myogenic precursors. For a comprehensive overview of this approach, we refer readers to recently published literature (Chal and Pourquie 2017; Kodaka et al. 2017; Selvaraj et al. 2019; Magli and Perlingeiro 2017).

ESCs are pluripotent cells that form the inner cell mass of blastocyst-stage embryos. These undifferentiated cells can expand indefinitely in vitro while maintaining the potential to differentiate into multiple cell types from the three embryonic germ layers (Martin 1981; Evans and Kaufman 1981; Thomson et al. 1998; Itskovitz-Eldor et al. 2000). Unlike ESCs, iPSCs are generated from adult somatic cells by overexpression of defined transcription factors (Takahashi and Yamanaka 2006; Takahashi et al. 2007). Since iPSCs can originate from an autologous cellular source, they could bypass immune rejection issues and ethical roadblocks associated with use of fetus-derived allogeneic ESCs (Takahashi and Yamanaka 2006).

Early studies revealed that both mouse and human PSCs can successfully differentiate into cells with myogenic potential (Barberi et al. 2007; Ozasa et al. 2007; Zheng et al. 2006; Mizuno et al. 2010; Dekel et al. 1992). Two major approaches have since been successfully employed to differentiate PSCs into myogenic cells: (i) transgene-dependent overexpression of canonical myogenic transcription factors and (ii) treatment with small molecules involved in differentiation-related signaling pathways (Kodaka et al. 2017; Chal and Pourquie 2017). Typical differentiation protocols occur in a two-dimensional monolayer or three-dimensional embryoid bodies. Given the highly heterogenous nature of these differentiated cultures, cell purification by surface markers indicative of muscle stem or progenitor cells is often employed (Kodaka et al. 2017; Chal et al. 2015).

Darabi and colleagues pioneering study first demonstrated that ectopic overexpression of the early developmental myogenic transcription factor Pax3 can form myogenic cells with capacity to engraft muscle in vivo (Darabi et al. 2008). A subsequent notable work further demonstrated that conditional Pax7 expression induces differentiation of human ESCs and iPSCs into expandable myogenic precursors (Darabi et al. 2012). Engrafted cells restored dystrophin expression in dystrophic murine muscles and donor-derived Pax 7 cells contributed to the satellite cell pool, highlighting the immense potential of PSC-derived myogenic precursors to remedy dystrophic symptoms (Darabi et al. 2011, 2012). A follow-up study further demonstrated that ESC-derived myogenic precursors engraft and can fuse to form dystrophin-positive myofibers in a model of severe muscular dystrophy (Filareto et al. 2012). Continued research followed a similar trajectory demonstrating efficient differentiation of ESCs and iPSCs into myogenic precursors or skeletal myocytes by overexpression of MyoD (Goudenege et al. 2012; Tanaka et al. 2013; Pawlowski et al. 2017; Maffioletti et al. 2015), Pax3, or Pax7 (Rao et al. 2018; Filareto et al. 2013). Whereas this approach was shown to be successful with respect to production of 
engraftable myogenic cells, the use of ectopic transgenes renders it less favorable for clinical application.

An alternative and safer method to facilitate conversion of PSCs into myogenic precursors is via small molecule treatment. Several recent studies have reported on PSC-differentiation into myogenic progenitors solely by small molecules which include bFGF, Forskolin and GSK3- $\beta$ inhibitor (GSK3- $\beta$ i) (Xu et al. 2013), GSK3- $\beta$ i and FGF2 (Shelton et al. 2014; van der Wal et al. 2018), WNT3A (Hwang et al. 2014), GSK3- $\beta$ i and DAPT (Choi et al. 2016), BMP4, TGF- $\beta$ and GSK3- $\beta$ inhibitors (Xi et al. 2017; Wu et al. 2018). A notable study by Chal and colleagues uncovered genetic pathways upregulated during paraxial mesoderm differentiation during mouse embryonic development, assisting in development of a step-wise differentiation protocol for derivation of myogenic precursors from PSCs by BMP4 and GSK3- $\beta$ inhibitor treatment (Chal et al. 2015). A follow-up study further refined this protocol by allowing for long-term capture of myogenic precursors in vitro when serum was added as a media supplement (Fig. 3) (Chal et al. 2018). The myogenic precursors both express Pax7 and promote muscle regeneration in dystrophic murine muscles, further contributing Pax7 positive cells to the satellite cell pool (Chal et al. 2015; Chal et al. 2018). Due to the heterogeneity of PSC-derived differentiated cultures reported using this protocol, myogenic precursors can be further purified by cell surface markers (Kim et al. 2017). Of note, such FACS-sorting techniques have been successfully employed by multiple studies to efficiently purify muscle precursors from PSC-differentiated cultures (Magli et al. 2017; Borchin et al. 2013; Wu et al. 2018; Kim et al. 2017; Hicks et al. 2018).

Patient-specific iPSCs from Duchenne patients carry the same mutation as their somatic parental cells (Park et al. 2008). Recent developments of the CRISPR-Cas9 genome editing system enable correction of the dystrophin mutation in iPSCs, followed by directed differentiation into dystrophin-positive muscle cells (Young et al. 2016; Li et al. 2015). Upon transplantation, corrected cells fuse to form dystrophin-positive myofibers within host murine muscles (Young et al. 2016). These findings illuminate the powerful therapeutic potential of combining genome engineering and stem cell differentiation methods to streamline new therapeutic treatments (Fig. 2d). However, the generation of gene-corrected iPSC-derived muscle stem cells in vitro remains a challenge (Ortiz-Vitali and Darabi 2019). For a comprehensive overview detailing PSC treatment methods of muscular dystrophies, we refer readers to recent reviews (Selvaraj et al. 2019; Ortiz-Vitali and Darabi 2019).

An additional approach for generating PSC-derived myogenic precursors is via in vivo developmental processes that can help further mature engrafted myogenic cells (Incitti et al. 2019). PSCs form tumors commonly known as teratomas upon in vivo engraftment, which contain differentiated cells indicative of all three embryonic germ layers (Ben-David and Benvenisty 2011). In a recent captivating study, Chan and colleagues capitalized on the PSC haphazard differentiation process during teratoma formation to detect and purify myogenic progenitors with an astounding regenerative capacity (Chan et al. 2018). FACS-sorted teratoma-derived $\alpha 7$ Integrin $^{+} / \mathrm{VCAM} 1^{+}$myogenic progenitors promoted robust regeneration upon 
engraftment into irradiated and cardiotoxin-injured dystrophic leg muscles in mice, restoring dystrophin expression in $80 \%$ of the tibialis anterior muscle and contributing up to $50 \%$ of the total DNA content (Chan et al. 2018). The teratoma-derived myogenic stem cells could further sustain regeneration in repeated injury and serial transplantation assays, demonstrating bona fide stem cell attributes. These cells exhibited a superior engraftment potential in comparison to previously published PSC-derived myogenic precursor cells (Chan et al. 2018). This remarkable contribution to muscle regeneration unleashes the vast potential of engrafted myogenic precursors to regenerate large muscle areas, which to date has only been achieved with partial success.

From a clinical perspective, a risk for teratoma formation by residual PSCs precludes facile adoption of this approach for therapy, and as such it will be of high interest to recapitulate this developmental process by a directed differentiation assay. To this end, single-cell sequencing could decipher the molecular trajectory PSC undergo during their differentiation into myogenic progenitors in teratomas. Such analysis may uncover candidate genes and signaling pathways that could be tested to produce teratoma-derived myogenic precursors in the culture dish, as was recently demonstrated for in vitro paraxial mesoderm and somite formation (Chal et al. 2018; Chal et al. 2015; Xi et al. 2017).

Prominent advances have been made in recent years in respect to generating PSCderived myogenic precursors with therapeutic applicability. However additional research is vital to translate bench lab findings to bedside treatments. Ethical limitations involving use of embryo-derived cells, risks for teratoma formation, and spurious differentiation of PSCs inhibit efforts to utilize PSC-derived myogenic cells to treat muscle-associated diseases. In respect to myogenic precursors, further investigation is certainly required to characterize the cells both molecularly and functionally, as well as devise safe and efficient protocols for their induction, purification, and in vitro maintenance. Future and ongoing human trials involving PSC-derived cells to treat diseases such as macular degeneration and Parkinson's disease hold paramount implications for assessing the therapeutic potential of PSC derived cells in clinical settings (Blau and Daley 2019). Successes are expected to expand the appetite for utilizing PSC-derived cells to treat other diseases, strengthen the nexus between scientists and clinicians, and may eventually destine PSC-based therapy to become a leading technology in regenerative medicine.

\section{Direct Reprogramming of Somatic Cells into Myogenic Progenitors}

Limitations of utilizing PSC-derived myogenic progenitors include both ethical and safety concerns and challenges associated with inducing PSCs to differentiate into adult mature cells. The aforementioned hurdles significantly hamper their utility in clinical settings, necessitating the search for additional approaches to produce expandable myogenic cells. An alternative method that can circumvent these challenges is direct lineage reprogramming, also known as "transdifferentiation." This 
approach denotes the conversion of one cell type into another by either ectopic overexpression of cell-type-specific transcription factors or small molecule treatment (Xu et al. 2015a). Historical pioneering studies spearheading this technique have shown that forced overexpression of the myogenic transcription factor MyoD in fibroblasts can convert them into skeletal myocytes via a short-lived myoblast stage (Davis et al. 1987; Weintraub et al. 1989; Tapscott et al. 1988). Since the landmark work by Davis and colleagues (Davis et al. 1987), a plethora of studies have reported on successful generation of various cell types by direct lineage reprogramming methods as reviewed (Xu et al. 2015a), including direct conversion into tissuespecific progenitors such as cardiac and neural precursors (Lalit et al. 2016; Lujan et al. 2012; Ring et al. 2012). Despite the formation of skeletal myocytes by MyoD overexpression being the first representation of direct lineage reprogramming, surprisingly only in recent years successful conversion into myogenic progenitors has been achieved (Ito et al. 2017; Bar-Nur et al. 2018; Lee et al. 2018; Sato et al. 2019; Bansal et al. 2019). We will next briefly introduce these new works, further highlighting unresolved issues and desired research directions spanning this technology.

Ito and colleagues were first to report that overexpressing various combinations of transcription factors such as Pax3, Pax7, Pitx1, Mef2b, and MyoD in mouse fibroblasts could give rise to myogenic progenitors (Ito et al. 2017). Reprogrammed myogenic progenitors upregulate satellite cell markers such as endogenous Pax 3 and Myf5, although intriguingly did not upregulate endogenous Pax7 expression (Ito et al. 2017). Additionally, the myogenic progenitors generated dystrophin-positive myofibers when injected into dystrophic murine muscles; however it is yet to be determined if these cells can contribute to the satellite cell pool in vivo (Ito et al. 2017). Another recent work reported on the conversion of fibroblasts into induced myogenic progenitor cells (iMPCs) by transient overexpression of MyoD in concert with three small molecules treatment (Bar-Nur et al. 2018). In stark contrast to overexpression of MyoD alone in fibroblasts, which generates myocytes (Davis et al. 1987), the combined treatment with Forskolin, a cyclic-AMP agonist, RepSox, a TGF- $\beta$ inhibitor, and CHIR-99021, a GSK3- $\beta$ inhibitor, surprisingly formed heterogenous cultures containing both undifferentiated progenitors and differentiated contractile myofibers (Bar-Nur et al. 2018). These progenitors can expand extensively in vitro, express high levels of endogenous Pax7 and Myf5, and engraft into both wild-type and dystrophic murine muscles (Fig. 3) (Bar-Nur et al. 2018). Remarkably, iMPCs efficiently contribute to the satellite cell pool and sustain multiple rounds of regeneration by repeated injury assay (Bar-Nur et al. 2018). Two additional reports have recently further demonstrated reprogramming of fibroblasts into induced myogenic precursor cells (Lee et al. 2018; Sato et al. 2019). Lee and colleagues have shown that overexpression of Six1, Eya1, Esrrb, and Pax3 can generate myogenic precursors that express endogenous Pax7 and fuse to form dystrophin-positive myofibers in dystrophic mice (Lee et al. 2018). In addition, Sato and colleagues established that overexpression of Pax3, Heyl, and KLF4 in concert with transient $\mathrm{MyoD}$ expression can generate myogenic precursors from both mouse and human fibroblasts (Sato et al. 2019), these precursors can expand 

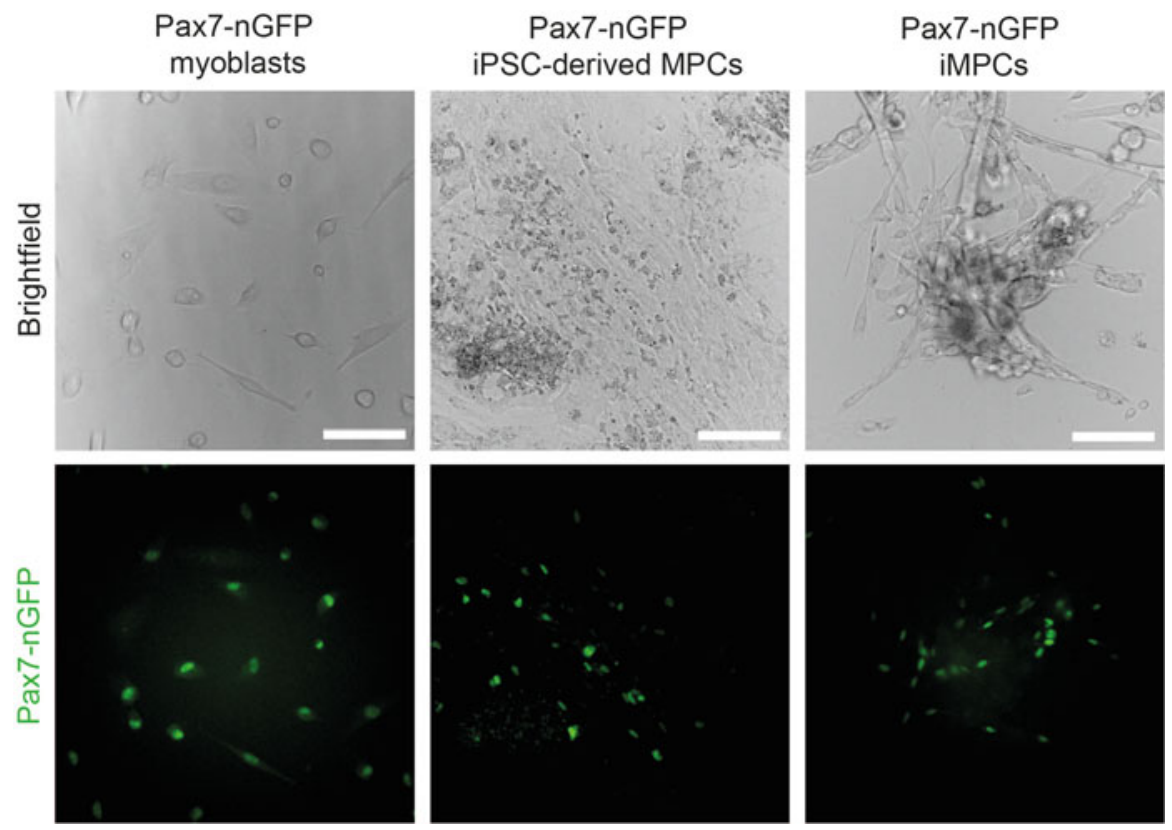

Fig. 3 Pax7 nuclear GFP reporter expression in cultured myoblasts, iPSC-derived myogenic precursors and fibroblast-derived induced myogenic progenitors (iMPCs). Scale bar, $100 \mu \mathrm{m}$

long-term, upregulate satellite cell markers such as Pax7, Spry1, and Sdc4, and efficiently engraft into dystrophic muscles including the satellite cell niche (Sato et al. 2019). It will be of interest to assess if the induced precursors are true myogenic stem cells that can both sustain regeneration in a repeated injury assay as well as maintain engraftment by serial transplantation. Lastly, a new report demonstrated that small molecule treatment alone in fibroblasts can elicit skeletal myocyte formation via a short-lived progenitor state (Bansal et al. 2019). Of note, several of the small molecules (i.e., Forskolin, RepSox and CHIR-99021) are identical to the ones used in conjunction with transient MyoD expression to form iMPCs (Bar-Nur et al. 2018) or maintain quiescence of satellite cells in vitro (Quarta et al. 2016). However, myogenic cells produced by small molecule treatment alone did not permanently capture a myogenic progenitor state in vitro nor was the capacity of the induced cells to contribute to muscle regeneration in vivo investigated.

Generation of induced myogenic precursor/progenitor cells by direct lineage reprogramming is an attractive approach to produce expandable cells for therapy; however notable challenges and unresolved questions remain. An interesting question that still requires further interrogation is how similar to one another are the induced cells generated by the aforementioned methods. Likewise, it will be of interest to assess how akin induced myogenic precursor/progenitor cells are molecularly and functionally to both myoblasts and satellite cells, and whether they are true myogenic stem cells that can sustain muscle regeneration by a serial 
transplantation assay. For translational purposes, future works will need to assess if these cells can be generated without integration of viral vectors, thus mitigating risks for insertional mutagenesis. To this end, synthetic mRNA transfection or protein transduction could be adapted to generate induced myogenic precursor/progenitor cells as was shown for iPSCs (Malik and Rao 2013). Similarly, production of these cells by small molecule treatment alone may provide a safer and more scalable approach to generate cells for translational purposes. Additional aspects of interest include disease modeling of muscular dystrophies using these cells and investigating their adoption for drug screens. In summary, this promising and nascent technique is in its infancy, and as such a litany of remaining questions will need to be thoroughly addressed prior to considering its potential use in clinical applications.

\section{$6 \quad$ Maintaining Satellite Cell Potency In Vitro}

Isolation of QSCs from skeletal muscle tissue is commonly performed by enzymatic digestion and mechanical breakage vital to dislodge the cells from their association with myofibers and the extracellular matrix (ECM). This harsh treatment mimics to an extent dissociation of satellite cells from their natural environment during injury or disease and likewise elicits rapid activation of myoblast-associated genes (Machado et al. 2017; Pietrosemoli et al. 2017; van Velthoven et al. 2017). Typically, freshly isolated satellite cells are separated from other mononucleated cell types by a pre-plating procedure or by FACS-sorting followed by seeding onto culture dishes coated with basement membrane substrates and in medium containing high serum levels and basic FGF (Rando and Blau 1994). Under these conditions, it was shown that nascent myoblasts rapidly proliferate and can fuse to form multinucleated myotubes in low serum conditions (Rando and Blau 1994). Upon further in vitro expansion, activated satellite cells promptly lose regenerative capacity as they form a population of proliferative myoblasts (Montarras et al. 2005). In the following section, we will outline various techniques that have been shown to ebb precocious differentiation of isolated satellite cells cultured in vitro and further augment their engraftment potential (Fig. 4a). We will focus on unique basement membrane substrates, treatment with small molecules, and induction of genes that promote an undifferentiated satellite cell state.

\subsection{Basement Membrane Proteins that Support an Undifferentiated Satellite Cell State}

During homeostasis native satellite cells are located between the sarcolemma and a structure of the basement membrane known as the basal lamina, providing an anatomical environment known as the "satellite cell niche." An intricate signaling crosstalk between the cells and their surrounding governs the satellite cell quiescent state (Rayagiri et al. 2018; Baghdadi et al. 2018). External stimuli such as the ones experienced during muscle injury and disease induce a signaling cascade that 
promote satellite cell activation and proliferation, which are imperative for muscle repair (Dumont and Rudnicki 2017). In their endogenous microenvironment, satellite cells are embedded in ECM, which encapsulate myofibers and is associated with different proteins during quiescence and activation, including laminins (Yao et al. 1996), fibronectin (Bentzinger et al. 2013), and collagen (Urciuolo et al. 2013). Conventional basement membrane proteins such as laminin-111, collagen I, Matrigel, and fibronectin are commonly used to expand satellite cells as myoblasts in vitro (Urciuolo et al. 2013; Maley et al. 1995; Grefte et al. 2012; Wilschut et al. 2010; Boonen et al. 2009; Duffy et al. 2016; Kuhl et al. 1986; Foster et al. 1987; Ocalan et al. 1988). These matrices are essential for attachment of freshly isolated satellite cells to the culture dish; however basement membrane proteins such as Matrigel are secreted by murine tumors and are composed of thousands of peptides, rendering them unsuitable for therapeutic applications in humans (Hughes et al. 2010). In addition, other basement membrane proteins confer on myoblasts reduced differentiation potential and loss of engraftment capacity during extended passaging. We will next discuss recent studies that set to uncover basement membrane proteins that could support satellite cell expansion while maintaining robust differentiation in vitro and high engraftment capacity in vivo.

Laminins (LMs) are active protein components of the ECM and belong to a glycoprotein family consisting of different chains including $\alpha, \beta$, and $\gamma$. (Colognato and Yurchenco 2000). These proteins can support in vitro growth of myoblasts, albeit which laminin components form the satellite cell niche or are upregulated during injury was only recently thoroughly assessed (Ishii et al. 2018; Rayagiri et al. 2018). In one recent study, extensive analysis of the different laminin isoforms in skeletal muscle revealed that the satellite cell niche is composed of LM- $\alpha 2, \mathrm{LM}-\alpha 3$, LM- $\alpha 4$, and LM- $\alpha 5$, which could then be mimicked in vitro by using Laminin E8 (LM-E8) fragments, which are truncated proteins composed of the $\alpha, \beta$, and $\gamma$ chains C-terminus domain (Ishii et al. 2018). Freshly isolated satellite cells cultured on LME8 derivative substrates remained undifferentiated in comparison to satellite cells cultured on Matrigel as indicated by higher quantities of proliferative $\mathrm{Pax} 7^{+} / \mathrm{MyoD}^{-}$ cells (Ishii et al. 2018). Furthermore, mouse and human satellite cells expanded on LM-E8 could robustly contribute to muscle regeneration in vivo and restore dystrophin expression in mouse dystrophic muscles (Ishii et al. 2018). Another recent study examined conventional substrates in the form of Matrigel and LM-111 to biologically relevant laminins present in muscles such as adult LM-211, embryonic LM-521, and others (Penton et al. 2016). This meticulous analysis demonstrated that freshly isolated mouse and human satellite cells cultured as myoblasts on LM-521 demonstrate a robust differentiation potential as assessed by myotube size and fusion index in comparison to myoblasts cultured on conventional basement membrane proteins (Penton et al. 2016). However, the number of Pax 7 and MyoD positive cells was similar among all tested conditions, and in vivo engraftment utilizing LM-521 cultured myoblasts was not assessed (Penton et al. 2016).

In concordance with these findings, a recent study reported that satellite cells regulate their quiescence via secretion of $L M-\alpha 1$, and genetic ablation of this protein impairs satellite cell self-renewal (Rayagiri et al. 2018). Similarly, another study 
demonstrated that collagen V (COLV) is produced by satellite cells and is key for their regeneration capacity, as blocking its production severely precludes satellite cell proliferation and leads to depletion of the satellite cell pool (Baghdadi et al. 2018). It will be of interest to assess if overexpression of LM- $\alpha 1$, LM-521, or COLV could maintain satellite cell characteristics in vitro and augment muscle engraftment of cultured cells. Determining which basement membrane protein can best support satellite cell proliferation, and differentiation is expected to yield widespread implications with respect to the potential of human satellite cells cultured on these unique matrices to regenerate muscles in vivo.

\subsection{Inhibition of Satellite Cell Differentiation by Small Molecules, Ligands, and Cytokines}

Disruption of satellite cell quiescence by injury or disease is accompanied by activation of cellular signaling cascades that promote proliferation and regeneration. However, these pathways are altered in high-passage myoblast cultures, which is one attribute to their loss of engraftment potential. Small molecules that affect signaling pathways could mitigate this effect and promote maintenance of satellite cell characteristics in vitro. We will briefly describe recent efforts to harness small molecules to culture and propagate satellite cells.

The p38 mitogen-activated protein kinase (MAPK) pathway is upregulated during activation of mouse satellite cells (Jones et al. 2005; Simone et al. 2004). Furthermore, previous studies documented that p38 inhibitor treatment of satellite cells attenuated muscle aging while increasing functionality of muscles in aged mice (Cosgrove et al. 2014; Bernet et al. 2014). Charville and colleague recently corroborated this observation by demonstrating that human satellite cells similarly upregulate p38 pathway in vitro, and its inhibition blunted the differentiation of satellite cells into committed myoblasts (Charville et al. 2015). Treatment of human ASCs with p38 MAPK inhibitor SB03580 reportedly increased proliferation rate while mitigating precocious differentiation into myoblasts and myotubes (Charville et al. 2015). Remarkably, SB03580-treated satellite cells robustly engrafted into healthy and dystrophic muscles in comparison to non-treated cells or freshly isolated satellite cell controls and could contribute cells to the muscle stem cell reservoir (Charville et al. 2015). Another study corroborated this finding by demonstrating that p38 inhibition maintains satellite cell-like phenotype and proliferation of freshly isolated bovine satellite cells (Ding et al. 2018).

Another well-studied pathway associated with satellite cell quiescence, activation, and differentiation is the Notch pathway(Mourikis and Tajbakhsh 2014), first reported to be upregulated during activation of satellite cells (Conboy and Rando 2002). Subsequent studies have documented that Notch and its downstream targets Hey1, HeyL, and Hes1 are highly expressed in QSCs and downregulated upon differentiation (Mourikis et al. 2012; Bjornson et al. 2012; Brohl et al. 2012). Abrogation of Notch in satellite cells mitigates their proliferation rate and elicits precocious differentiation into mature muscle cells (Mourikis et al. 2012; Bjornson 
et al. 2012; Brohl et al. 2012). In line with these observations, overexpression of Notch-1 abolishes expression of muscle-associated differentiation genes (Conboy and Rando 2002), and overexpression of constitutively active intracellular domain of Notch1 (NICD1) can rescue precocious differentiation in satellite cells lacking Pax7 (Pasut et al. 2016). Different Notch ligands have been implicated in regulating satellite cell quiescence and self-renewal (Baghdadi et al. 2018; Low et al. 2018; Verma et al. 2018). Of note, a recent study highlighted the role of endothelial cells in maintenance of satellite cell quiescence through the Notch ligand Dll4 (Verma et al. 2018).

These collective findings suggest that manipulating the Notch pathway could impact proliferation and differentiation potential of cultured satellite cells and myoblasts. Indeed, Parker and colleagues were first to report that culturing canine freshly isolated satellite cells in conditions that promote Notch activation blunted differentiation and facilitated muscle engraftment, strikingly in equal levels to those of freshly isolated canine satellite cells (Parker et al. 2012). Similarly, mouse and human satellite cells expanded on Notch ligands reportedly proliferated better, elevated expression level of Notch downstream targets, and reduced expression of differentiation-associated genes (Sakai et al. 2017). However, contribution of cells to engraftment in host muscles was similar between treated and control cells (Sakai et al. 2017). In another recent work, Gerli and colleagues cultured freshly isolated satellite cells and myoblasts on Dll4 ligand in concert with PDGF-BB supplementation (Gerli et al. 2019). This treatment attenuated proliferation and differentiation of cultured satellite cells, increased the proportion of $\mathrm{Pax}^{+} / \mathrm{MyoD}^{-}$cells and elevated expression of Notch and its downstream targets (Gerli et al. 2019). The authors hypothesize that the combined treatment augments perivascular and satellite cell attributes in cultured myoblasts (Gerli et al. 2019). However, the in vivo capacity of treated myoblasts to engraft into muscles in vivo is yet to be determined (Gerli et al. 2019). Collectively, conflicting reports exist with respect to the capacity of Notch ligands to enhance engraftment of cultured myoblasts in vivo; however this pathway undisputedly helps in sustaining satellite cell attributes in vitro. More work is required to resolve if alteration of this pathway can enhance engraftment of myogenic cells in vivo.

Forskolin is a small molecule that has been recently implicated in enhancement of muscle stem or progenitor cell proliferation and engraftment potential $\mathrm{Xu}$ et al. 2013; Bar-Nur et al. 2018; Quarta et al. 2016). Forskolin increases cAMP intracellular levels that further activate the protein kinase A (PKA) pathway, which subsequently phosphorylates the transcription factor cAMP response element-binding protein (CREB). Activation of this pathway was previously shown to be essential for WNT-related induction of embryonic myogenesis (Chen et al. 2005). Recent works implicated Forskolin in enhancing expansion of mouse satellite cells in vitro (Xu et al. 2013). Freshly isolated satellite cells cultured in the presence of Forskolin retained satellite cell characteristics in vitro, and treated cultures could engraft robustly into dystrophic mouse muscles (Xu et al. 2013). Forskolin is also a component of a small molecule cocktail which reportedly maintains muscle stem cell quiescence in vitro in conjunction with engineered muscles fibers (Quarta et al. 
2016). This artificial construct can regenerate muscle in vivo upon engraftment (Quarta et al. 2016). Lastly, forskolin is one of three small molecules that have been reported as critical for induction and proliferation of induced myogenic progenitor cells from fibroblasts in concert with MyoD (Bar-Nur et al. 2018).

Muscle damage initiates infiltration of white blood cells to the injury site, where these cells play important role in muscle repair via secretion of cytokines (Wosczyna and Rando 2018). Growing amount of evidence suggest that cytokines can directly affect satellite cells and myoblasts. Notable examples include leukemia inhibitory factor (LIF), which reportedly increases the proliferation of cultured myoblasts (Austin and Burgess 1991; Austin et al. 1992; Alter et al. 2008). Accordingly, LIF was recently shown to effectively enhance the transplantation potential of freshly isolated myoblasts in a DMD mouse model, presumably by attenuating apoptosis (Ito et al. 2016). LIF is one of several members of the IL-6 cytokine family, which includes IL-6, IL-27, IL-11, and Oncostatin (OSM) (Stefan Rose-John 2018). It functions by binding to the LIfr/gp130 receptor which activates JAK1 signaling cascade leading to phosphorylation and activation of the transcription factor Stat3 (Nicola and Babon 2015). Similarly, IL-6 is a proinflammatory cytokine which is upregulated during the initial phase of muscle regeneration and mediates its effect through Stat3 downstream activation (Munoz-Canoves et al. 2013). Stat3 pathway is crucial for myogenic differentiation, and absence of Stat 3 signaling perturbs efficient muscle regeneration (Tierney et al. 2014; Wang et al. 2008; Sun et al. 2007). Accordingly, IL-6 supplementation upregulates MyoD expression through Stat3 signaling, promoting muscle regeneration (Tierney et al. 2014). Attenuating Stat3 expression enhances myoblasts proliferation; however engraftment potential of these cells was not assessed (Tierney et al. 2014). In accordance with this observation, another cytokine of the IL-6 pathway that activate the Stat3 pathway is OSM, which reportedly blocks differentiation of myoblasts and keeps them in a progenitor-like state (Xiao et al. 2011). A recent study revealed that OSM is secreted by muscle fibers, exerting a quiescent phenotype on muscle stem cells (Sampath et al. 2018). OSM treatment of cultured myoblasts maintains their stemness in vitro as judged by Pax7-GFP reporter expression, and this treatment dramatically enhances myoblast engraftment potential and further enables serial transplantation of cells (Sampath et al. 2018). Wnt4 is another recently reported niche-specific factor secreted from myofibers that regulates satellite cell quiescence (Eliazer et al. 2019). It will be of interest to assess if akin to OSM treatment of freshly isolated satellite cells, administration of Wnt 4 can help support in vitro muscle stem cell quiescence and enhance in vivo engraftment potential. Building upon the notable effects cytokines have on muscle stem cells, Fu and colleagues screened multiple proinflammatory cytokines to find combinations of cytokines that promote satellite cell expansion ( $\mathrm{Fu}$ et al. 2015). This effort uncovered culture conditions that consist of the T-cell secreted cytokines IL- $1 \alpha$, IL-13, TNF- $\alpha$, and IFN- $\gamma$ to support extensive expansion of satellite-like cells (Fu et al. 2015). Expanded cells treated in these conditions could very efficiently engraft into muscles and further replenish the satellite cell reservoir (Fu et al. 2015). 


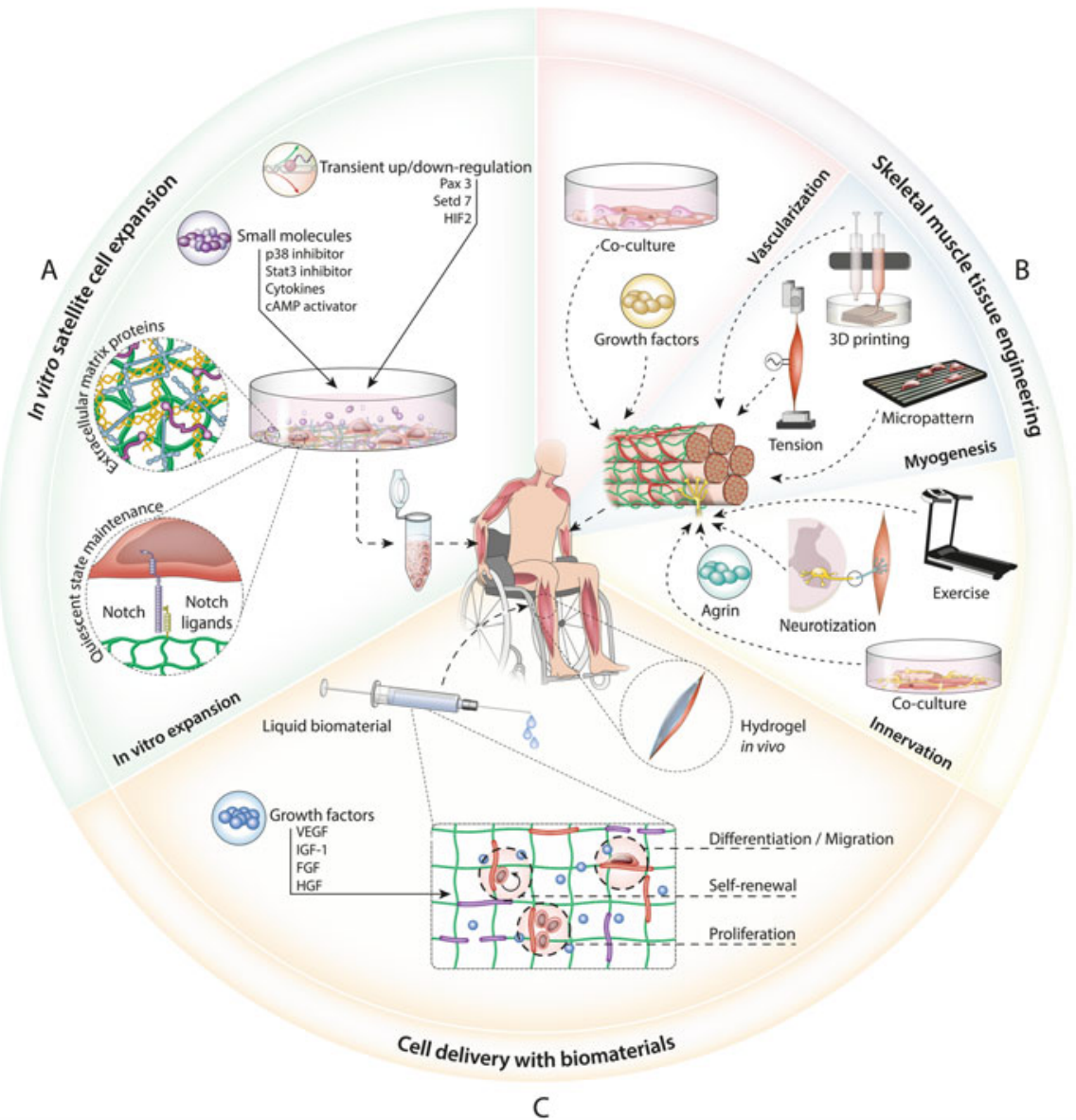

Laminin $\int_{\text {Fibronectin }}$ Collagen $\int$ Degradable cross linkers $\int$ Cell-adhesive peptides

Fig. 4 Biomaterial and tissue engineering strategies to enhance satellite cell expansion, engraftment and reconstruction of skeletal muscle tissue. (a) Select approaches to expand satellite cells in vitro while maintaining in vivo engraftment potential. Different methods can be utilized including expansion on unique basement membrane proteins, treatment with small molecules and induction or repression of genetic pathways. (b) Tissue engineering approaches to treat severe muscle dystrophy or VML using in vitro generated muscle bioconstructs which consist of satellite cells, MRCs, and aligned, multinucleated myofibers. Bioconstruct can be further innervated or vascularized to facilitate engraftment and retention of grafts in muscles. (c) Strategies to enhance satellite cell engraftment using injectable biomaterials which extend satellite cell viability and retention at the injury site 


\subsection{Genetic Alteration that Support Satellite Cell Self-Renewal and Regeneration}

Aside from basement membrane proteins and small molecule treatment, alteration of genes and genetic pathways is an additional method to augment satellite cell expansion potential. An elegant manifestation of this approach was recently reported by Filareto and colleagues who demonstrated that transient overexpression of the transcription factor Pax3 in freshly isolated satellite cells abates spontaneous differentiation into myoblasts, and further enhances cell proliferation without compromising satellite cell capacity to give rise to myotubes in response to differentiation cues (Filareto et al. 2015). Moreover, treated satellite cells could robustly restore dystrophin expression in DMD mice and contribute cells to the satellite cell pool (Filareto et al. 2015). To further investigate the translation potential of this approach, freshly isolated satellite cells extracted from DMD mice were subjected to transient Pax3 overexpression and infected with a construct encoding human micro-dystrophin (Filareto et al. 2015). Following this procedure, cells were engrafted into dystrophic mouse muscles and could restore dystrophin expression and remedy symptoms of the affliction, demonstrating an elegant autologous satellite cell-based approach to treat DMD in a mouse model (Filareto et al. 2015), which can be adapted to humans (Fig. 2b).

A few additional studies have recently reported means to sustain satellite cell expansion in vitro by altering genetic pathways. One study demonstrated that deletion of the lysine methyltransferase Setd7 enables in vitro expansion of undifferentiated freshly isolated human and mouse satellite cells and could further enhance their engraftment potential in vivo (Judson et al. 2018). This phenotype is mediated via interaction of Setd 7 with $\beta$-catenin and modification of its methylation state, which subsequently induces a differentiation myogenic gene commitment program that is abated in Setd7 deleted cells (Judson et al. 2018). Inhibition of Setd 7 can be mimicked by pharmacological treatment, providing a facile approach to utilize this method for therapeutic interventions (Judson et al. 2018). Another study reported that inhibition of HIF2A support satellite cell proliferation (Xie et al. 2018). Quiescent satellite cells express the hypoxia-inducible factor 2A (HIF2A) and are in a hypoxic state during homeostasis (Xie et al. 2018). This state is rapidly altered in normoxic state during in vitro growth (Xie et al. 2018). Capitalizing on this unique observation, it was shown that short-lived inhibition of HIF2A by pharmacological modulation accelerates muscle stem cell proliferation, while deletion of HIF2A abrogates muscle regeneration due to depletion of the satellite cell reservoir (Xie et al. 2018). It will be of interest to assess whether satellite cells subjected to this short-lived treatment can better engraft into muscles in vivo.

Culturing satellite cells using the aforementioned treatments has been demonstrated to mitigate precocious differentiation and enhance engraftment potential of cells. Further research is required to investigate the mode of action by which these treatments work. Additionally, a manifold of these studies have been reported in mouse cells, and it is of interest to assess which method can efficiently adapt to expand human satellite cells. Lastly, it will be of interest to investigate the effects of 
combinatorial administration of small molecules on human satellite cells to assess if combined treatment can facilitate the expansion and engraftment of cells in comparison to individual treatment.

\section{$7 \quad$ Enhancing Muscle Stem Cell Engraftment Using Biomaterials}

Delivery methods of myogenic cells into recipient muscles could impact translational outcomes by increasing engraftment efficacy and decreasing the requirement for high quantities of donor-derived satellite cells (Fig. 4c) (Boldrin et al. 2007). In early myoblast transplantation trials, engrafted cells were typically resuspended in HBSS or PBS prior to injections (Huard et al. 1992; Tremblay et al. 1993a; Mendell et al. 1995). However, aftereffects of these trials were disappointing, and low cell survival may have accounted for the unfavorable outcome (Beauchamp et al. 1999). This observation raises an interesting question whether delivery of muscle stem or progenitors cells in conjunction with unique substances such as biomaterials could manifest better therapeutic outcomes.

Biomaterials are defined as a synthetic or natural substance, or combination of substances, that can remedy or replace tissues and organs in the body (National Institutes of Health Consensus Development 1983). To date, numerous natural and synthetic biomaterials have been widely investigated for their potential to boost skeletal muscle regeneration (Cezar and Mooney 2015; Qazi et al. 2015). Biomaterials can encapsulate cells, for instance, in the form of soft hydrogels that are created by the crosslinking of hydrophilic polymers or 3D scaffolds, which are generated by various techniques including chemical crosslinking, freeze-drying, or electrospinning (Qazi et al. 2015; Wolf et al. 2015; Hu et al. 2019). An injectable or implantable biomaterial can protect the engrafted cells from apoptosis and increase cell proliferation while negating immunological responses (Han et al. 2017). Moreover, degradable biomaterials can be replaced over time by a regenerated tissue, which is important once a therapeutic objective is achieved (Han et al. 2017). Commonly used biomaterials which have been reported to sustain cell delivery into skeletal muscle tissue include natural alginate (Wang et al. 2014; Hill et al. 2006), hyaluronic acid (HA) (Rossi et al. 2011; Davoudi et al. 2018), ECM (Rao et al. 2017), or fibrin (Matthias et al. 2018; Page et al. 2011; Gerard et al. 2012), as well as synthetic scaffolds in the form of poly(ethylene glycol) (PEG) (Han et al. 2018, 2019), poly(lactic-co-glycolic acid) (PLGA) (Boldrin et al. 2007, 2008), or a combined PEG-fibrinogen constructs (Fuoco et al. 2012, 2014, 2015).

Several studies have reported on the beneficial effects of utilizing synthetic or natural biomaterials during myoblast engraftment into murine muscles (Boldrin et al. 2007, 2008; Hill et al. 2006; Wang et al. 2014; Rao et al. 2017). For example, high quantities of donor-derived myofibers were detected when myoblasts were encapsulated inside micropatterned PGA scaffolds and engrafted into pre-injured mouse muscles (Boldrin et al. 2007, 2008). A subsequent study demonstrated enhanced muscle regenerative capacity upon delivery of myoblasts embedded in alginate 
scaffolds compared to injection of cells alone (Hill et al. 2006). In these studies, scaffolds containing myoblasts in their native size were implanted into muscles (Boldrin et al. 2007, 2008; Hill et al. 2006). However, an injectable biomaterial could additionally enable a less invasive cell delivery method (Qazi et al. 2015). This can be achieved by using shape-memory scaffolds (Wang et al. 2014) or injectable biomaterials that can be polymerized into gels in situ due to a temperature shift (Davoudi et al. 2018), light (Rossi et al. 2011; Fuoco et al. 2015), or ions (Sleep et al. 2017). Shape-memory scaffolds can be compressed during transplantation and then expand back to their original size in situ (Lendlein and Langer 2002). An alginatebased shape-memory scaffold has been suggested as a vehicle for myoblast delivery, as it enables a minimally invasive transplantation procedure (Wang et al. 2014). Upon engraftment into pre-injured muscles, increased myoblast viability, muscle regeneration, and reduced fibrosis were reported (Wang et al. 2014). Further, robust myoblast proliferation and engraftment efficacy were demonstrated upon assembly of myogenic cells inside an ECM hydrogel and injection into ischemic muscles in conjunction with fibroblasts (Rao et al. 2017).

Prolonged in vitro expansion of myoblasts reduces engraftment potential as compared to freshly isolated satellite cells (Montarras et al. 2005). As such, biomaterial-based delivery of satellite cells has been recently investigated with hope of increasing engraftment efficacies (Sleep et al. 2017; Davoudi et al. 2018; Han et al. 2018, 2019; Rossi et al. 2011). In a notable study, Rossi and colleagues delivered myoblasts or satellite cells embedded in a photocrosslinkable hyaluronan hydrogel into pre-injured mouse muscles, reporting both increased detection of donor-derived myofibers and improved contraction forces (Rossi et al. 2011). Recently, Sleep and colleagues reported on a method to embed satellite cells in a liquid crystalline scaffold prior to intramuscular injections (Sleep et al. 2017). The scaffold stiffness was adjusted to physiological values, in agreement with previously published works highlighting the effects of mechanical properties on myogenesis (Engler et al. 2004; Gilbert et al. 2010; Sleep et al. 2017). Utilizing a unique apparatus that forms aligned scaffolds in vivo, freshly isolated satellite cells were encapsulated in a biomimetic scaffold and engrafted into muscles, demonstrating robust regeneration in comparison to control non-encapsulated cells (Sleep et al. 2017). Of interest, the scaffold degradation pace was akin to the typical time period necessary for muscle tissue regeneration, leading the authors to suggest that this temporal concordance is key for vascularization and innervation of the regenerating tissue (Sleep et al. 2017).

In a recent study, a hydrogel-based cell delivery system promoting cell viability, proliferation, and differentiation has been reported (Han et al. 2018). The synthetic hydrogel consisted of both four-arm PEG and maleimide groups (PEG-4MAL) and was further functionalized with arginine, glycine, and aspartic acid (RGD) peptides (Han et al. 2018). RGD motifs are found in fibronectin and other extracellular matrix proteins that are essential for both satellite cell expansion and myoblast differentiation (Ruoslahti and Pierschbacher 1987; Garcia et al. 1999; Lukjanenko et al. 2016) and are frequently used to support cell adhesion (Wang et al. 2014; Hill et al. 2006; Han et al. 2018, 2019; Borselli et al. 2011). Utilizing this delivery system, RGD functionalized hydrogels increased freshly isolated satellite cell viability, 
proliferation, and migration, and the RGD adhesive sites were key for cell fusion in vitro (Han et al. 2018). Of interest, utilizing a protease-degradable crosslinker enabled degradation of the hydrogel and further enhanced cell viability and proliferation in vitro (Han et al. 2018). Lastly, satellite cell survival and proliferation were also improved via hydrogel delivery during "supra-muscular" injections onto the muscle surface of aged or dystrophic mice (Han et al. 2018). In another notable study, Davoudi and colleagues demonstrated that satellite cell delivery in a hyaluronan and methylcellulose (HAMC) hydrogel resulted in a $45 \%$ increase of donor-derived myofiber engraftment compared to saline control (Davoudi et al. 2018). The authors noted improved dispersion of regenerated myofibers, suggesting that cell migration was enhanced by use of the hydrogel (Davoudi et al. 2018). They further conducted several experiments to elucidate the mechanisms governing the enhanced engraftment observed with HAMC usage (Davoudi et al. 2018). For instance, hydrogels have been shown to protect various cells from mechanical forces during the injection process (Aguado et al. 2012). To note, HAMC did not affect the viability of extruded satellite cells however led to a $6 \%$ increase in cell number (Davoudi et al. 2018). Collectively, the authors suggest that the enhanced engraftment could be attributed to elevated muscle stem cell proliferation, protection from active clearance by the immune system and detaining precocious differentiation (Davoudi et al. 2018).

An additional advantage of cell encapsulation inside biomaterials entails the potential of cell delivery with incorporation of various growth factors. Whereas growth factors mixed in a saline solution tend to diffuse rapidly inside a recipient tissue, a scaffold can support gradual release of growth factors into the tissue (Qazi et al. 2015; Han et al. 2017; Sleep et al. 2017). To this end, Borselli and colleagues encapsulated myoblasts in conjunction with the growth factors VEGF and IGF-1 inside an alginate scaffold and delivered the bioconstruct into pre-injured murine muscles (Borselli et al. 2011). This technique reportedly improved cell engraftment and further stimulated vascularization and myogenesis in the host tissue (Borselli et al. 2011). In another study, Hill and colleagues embedded myoblasts in an alginate scaffold in the presence of HGF and FGF2 prior to delivery (Hill et al. 2006). They reported increased cell viability, prevention of terminal differentiation, and improved regeneration in muscles engrafted with this construct (Hill et al. 2006). Additional studies further demonstrated that sustained release of bFGF from engineered constructs facilitated myoblast or satellite cell engraftment (Hagiwara et al. 2016; Sleep et al. 2017). Lastly, another recent report demonstrated the assembly of a PEG4MAL hydrogel with muscle stem cells and the protein Wnt7a (Han et al. 2019), a pro-myogenic factor involved in muscle repair and stem cell migration (von Maltzahn et al. 2011; Bentzinger et al. 2014). This effort has led to an increase in muscle mass and regeneration following construct delivery into pre-injured muscles and strikingly also elevated stem cell migration (Han et al. 2019). Collectively, the aforementioned reports suggest that the delivery of biomaterials together with unique small molecules and growth factors could augment myogenic engraftment efficacy. 
The various studies discussed in this section indicate that synthetic or natural materials can enhance muscle stem cell engraftment. However, the molecular mechanisms that mediate this process are not completely understood and additional research is warranted. Furthermore, it will be of interest to assess whether combining different cell types inside a biomaterial could enhance regeneration capacity. Ideal candidates include cell types that are associated with skeletal muscle repair (Wosczyna and Rando 2018), such as resident endothelial cells, fibro-adipogenic progenitors, or macrophages which reportedly promote muscle regeneration (Lukjanenko et al. 2019; Wosczyna et al. 2019; Latroche et al. 2017; Joe et al. 2010). Collectively, amassing inside a biomaterial multiple cell types native to muscle tissue and essential for its repair could boost the therapeutic competence of this tissue engineering approach.

\section{Stem Cell-Based Approaches to Engineer Skeletal Muscle Tissue}

Volumetric muscle loss (VML) denotes the irrecoverable structural and functional deficits of skeletal muscle tissue induced by acute injury or surgical removal (Greising et al. 2019). Due to extensive muscle loss, satellite and other muscle resident cells fail to repair the tissue damage which is often times replaced by fibrotic tissue (Greising et al. 2019; Corona et al. 2019). Harvest of healthy muscle fragments known as "muscle flaps" followed by engraftment into VML-afflicted muscle sites can partially treat this muscle loss; however this complicated surgery is often associated with donor site morbidity (Lin et al. 2007; Klinkenberg et al. 2013; Gilbert-Honick and Grayson 2019). Several late-stage muscular dystrophies such as DMD share resemblances to VML, as the muscle tissue is both severely damaged and typically replaced by adipogenic and fibrotic tissues (Klingler et al. 2012; Hooijmans et al. 2017; Skuk et al. 2007). If an entire muscle segment is acutely damaged, muscle stem cells cannot efficiently regenerate skeletal muscle, and myogenic cell engraftment is expected to fail in the absence of a supportive tissue. Notably, this has previously been shown for DMD patients following allogeneic myoblast transplantation, which was reportedly effective when cells were engrafted into an intact muscle tissue, however failed to engraft following injections into highly dystrophic muscles devoid of parenchyma (Skuk et al. 2007). An alternative therapeutic approach to cell transplantation involves reconstructing a functional skeletal muscle tissue in vitro that could incorporate into VML-afflicted muscle sites or acutely dystrophic muscles (Fig. 4b) (Juhas and Bursac 2013). In the following section, we will highlight attempts to engineer tissue-like muscle constructs in vitro utilizing myogenic stem or progenitor cells seeded on designated scaffolds prior to engraftment. For further reading into other approaches that involve tissue engineering of skeletal muscle, we refer the readers to recently published literature (Kwee and Mooney 2017). 


\subsection{Engineering Skeletal Muscle Tissue In Vitro Using Myogenic Precursors}

Historically, early attempts to engineer bioartificial skeletal muscle tissue utilized avian myotubes or immortalized mouse myoblast cell lines such as C2C12 (Vandenburgh and Kaufman 1979; Vandenburgh et al. 1988, 1998, 1996). The latter have been oftentimes used as "biological vehicles" to deliver growth factors into muscle tissue (Vandenburgh et al. 1996, 1998). Vandenburg and colleagues reported on a method to produce a bioartificial muscle (BAM) consisting of parallel myotubes that upon muscle engraftment secreted recombinant human growth factors and attenuated muscle atrophy in mice (Vandenburgh et al. 1998). The BAM was formed by coalescing collagen and Matrigel with $\mathrm{C} 2 \mathrm{C} 12$ myoblasts, which were genetically engineered to express a specific growth factor (Vandenburgh et al. 1988). This pregel solution was allowed to solidify in long casts, thus forming aligned myotubes which were successfully subcutaneously transplanted (Vandenburgh et al. 1996, 1998). Multiple groups have since utilized C2C12 to produce muscle constructs in vitro by various tissue engineering techniques (Engler et al. 2004; Costantini et al. 2017; Zhang and Guo 2017; Kang et al. 2016). Furthermore, C2C12 has also been incorporated into engineered muscle constructs to replace muscle tissue in vivo (Levenberg et al. 2005; Koffler et al. 2011; Kaufman et al. 2019). While these studies provided the experimental framework to engineer skeletal muscle cells, $\mathrm{C} 2 \mathrm{C} 12$ is an immortalized cell line which is physiologically distinct from normal myogenic cells, necessitating usage of physiologically relevant and therapeutically acceptable primary cells (Yaffe and Saxel 1977; Morgan et al. 1992; Wernig et al. 1991). To this end, skeletal muscle constructs have also been generated from primary myogenic cells derived from rodent (Juhas et al. 2014; Corona et al. 2014; Machingal et al. 2011) or human (Gholobova et al. 2015; Quarta et al. 2017; Madden et al. 2015; Powell et al. 1999) sources. To induce muscle construct formation, parallel alignment of differentiated myotubes is typically generated by patterned scaffolds and substrates (Neal et al. 2014; Kang et al. 2016; Takahashi et al. 2013; Bian et al. 2009; Nakayama et al. 2019), or platforms that induce unidirectional tension in muscle bundles (Powell et al. 1999; Gholobova et al. 2015; Vandenburgh et al. 1998). A uniform muscle architecture has been elegantly demonstrated using parallel multinucleated myofibers and sarcomeric striations (Juhas et al. 2014; Madden et al. 2015). Moreover, several studies reported on functional muscle contractions involving active calcium signaling in vitro and contribution to force generation in vivo (Madden et al. 2015; Quarta et al. 2017; Vandenburgh et al. 2008). Interrogating the regeneration potential of an engineered muscle construct in vitro is key for predicting therapeutic outcomes in vivo. This can be achieved by inflicting muscle damage and recording the regeneration capacity of the engineered tissue in vitro (Juhas et al. 2014). In a notable study, Juhas and colleagues generated 3D engineered muscle bundles from neonatal rat myogenic cells and intriguingly observed Pax 7 satellite-like cells under the basal lamina in these constructs (Juhas et al. 2014). In concordance with this observation, the engineered construct could 
regenerate muscle fibers in vitro following localized cardiotoxin muscle injury (Juhas et al. 2014).

An alternative myogenic cell source for tissue engineering of skeletal muscle are iPSCs, as they can potentially differentiate into an unlimited number of myogenic precursors that can be used for muscle reconstruction (Pantelic and Larkin 2018; Del Carmen Ortuno-Costela et al. 2019). Rao and colleagues recently reported on the first generation of functional skeletal muscle tissue entirely from human iPSCs (Rao et al. 2018). Human iPSCs were exposed to the GSK3- $\beta$ inhibitor CHIR-99201 in conjunction with transient Pax7 overexpression, resulting in differentiation into myogenic precursors that express endogenous Pax 7 (Rao et al. 2018). These cells were further cultured in 2D dishes or in 3D fibrin hydrogels (Rao et al. 2018). The authors demonstrated that using a 2D culture system, skeletal muscle was partially formed, while usage of the 3D culture system gave rise to mature muscle bundles that expressed adult myosin heavy chain isoforms (Rao et al. 2018). Strikingly, the muscle bundles were functional in vitro and in vivo as demonstrated by induction of contractions and calcium transits using electrical and chemical stimuli (Rao et al. 2018).

Collectively, the findings described thus far illustrate eminent advancements in skeletal muscle cell organization in vitro; however engineering functional muscle tissue is expected to require vascularization and innervation of the muscle constructs. In the next sections we will briefly describe methods to vascularize or innervate in vitro engineered muscle cells.

\subsection{Vascularization of Skeletal Muscle Tissue Constructs}

Skeletal muscle is a highly vascularized tissue, as blood vessels are essential for in vitro formation of large-sized tissue since they enable nutrient and oxygen supply across large tissue segments (Kaully et al. 2009). Several studies have therefore investigated the ability to vascularize tissue-engineered muscle constructs by in vivo endothelial cell recruitment or in vitro pre-vascularization (Gilbert-Honick and Grayson 2019). With respect to the first approach, some studies reported on host vessel infiltration into small muscle constructs (Juhas et al. 2014; Kang et al. 2016); albeit for larger muscle constructs this is deemed a limiting factor. To address this limitation, several studies documented recruitment of host blood vessels by engineering cells or scaffolds to secrete growth factors such as VEGF to facilitate vessel migration (Zhou et al. 2015; Koffler et al. 2011; Osaki et al. 2018a; Borselli et al. 2010). In one notable study, muscle constructs consisting of myoblasts that ectopically express VEGF have been reported to induce robust vascularization in vivo (Zhou et al. 2015). Furthermore, interactions between C2C12-derived muscle bundles that ectopically express angiopoietin- 1 and endothelial cells have been studied (Osaki et al. 2018a). Angiopoietin-1 secretion evoked endothelial cell sprouting toward the muscle fiber bundles, and this interaction increased myofiber contraction force strength (Osaki et al. 2018a). 
Whereas enhancement of host cell infiltration is a promising research direction, replacing a muscle tissue in vivo may be more advantageous for therapy if the tissue is composed of multiple cell types with different physiological roles. Co-culturing myoblasts together with endothelial cells is an established method to improve vascularization of muscle grafts (Levenberg et al. 2005; Koffler et al. 2011; Gholobova et al. 2019; Nakayama et al. 2019). For example, co-culturing murine myoblasts with endothelial cells and fibroblasts have been reported to form muscle constructs consisting of vascular networks in vitro (Levenberg et al. 2005), and these findings were further recapitulated using human cells (Gholobova et al. 2015, 2019; Maffioletti et al. 2018). In a recent study, Kaufman and colleagues investigated vascularization of muscle grafts consisting of $\mathrm{C} 2 \mathrm{C} 12$, endothelial cells, and fibroblasts in mice afflicted with injured abdominal walls (Kaufman et al. 2019). Utilizing this approach, robust graft integration into host muscles has been documented, consisting of parallel donor-derived myotubes and absence of fibrotic structures (Kaufman et al. 2019). Similarly, using human umbilical vein endothelial cells (HUVECs) with human myoblasts reportedly created endothelial cell networks in BAM constructs, highlighting the importance of vascularization of myotubes for production of larger bio-artificial muscle constructs (Gholobova et al. 2019). Lastly, patterned scaffolds seeded with myoblasts and vascular endothelial cells have been recently demonstrated to positively guide parallel myotube alignment and organize microvasculature of engineered skeletal muscle constructs (Nakayama et al. 2019). In comparison to randomly aligned myotubes, these parallel aligned myofibers gave rise to coordinated contractions, upregulation of myogenic genes, and exceedingly improved integration into VML lesions in a mouse model (Nakayama et al. 2019). This work highlights the potential of combining endothelial cells in concert with unique scaffolds to induce vascularization in addition to muscle regeneration upon engraftment.

\subsection{Innervation of Skeletal Muscle Tissue Constructs}

Motor neurons induce muscle contractions via secretion of neurotransmitters in neuromuscular junctions (Slater 2017). This intricate molecular crosstalk allows muscle innervation by motor neurons, a process which plays a pivotal role in skeletal muscle function, and its derailment rapidly elicits muscle atrophy (Afshar Bakooshli et al. 2019; Osaki et al. 2018b; Kaufman et al. 2019). Generation of tissueengineered muscle constructs therefore may require extensive innervation to enable optimal graft function inside host muscles. To this end, multiple factors have been assessed with respect to their capacity to innervate muscle constructs including neurotization (Dhawan et al. 2007; Kaufman et al. 2019), chemicals (Wang et al. 2013; Ko et al. 2013), co-culture with neural cell types (Larkin et al. 2006; Morimoto et al. 2013; Afshar Bakooshli et al. 2019), and exercise (Quarta et al. 2017).

Neurotization is a well-established method that can elicit tissue innervation via transfer of host nerves into a de-innervated tissue. For example, attaching an engineered muscle construct to femoral nerves reportedly increases innervation of 
flaps (Kaufman et al. 2019). Innervation of muscle tissue is key for achieving therapeutic success as lack of innervation in muscle flaps culminates in adipogenic or fibrotic tissue replacement (Chang et al. 2018). Furthermore, proper innervation of muscle constructs has also been associated with enhanced muscle maturation and increased force production (Dhawan et al. 2007).

Aside from neurotization, "preconditioning" innervation in vitro could also provide means to accelerate innervation in vivo, particularly for large muscle constructs (Ko et al. 2013). This can be achieved by inducing expression of acetylcholine receptors which are pivotal for neuromuscular junction function (Ko et al. 2013). To this end, multiple studies have reported on beneficial effects for utilizing the motor neuron secreted factor agrin on skeletal muscle cells (Bian and Bursac 2012; Bentzinger et al. 2005; Bezakova and Ruegg 2003). Agrin is an acetylcholine receptor cluster-inducing factor and accordingly muscle constructs that were pre-treated with agrin prior to transplantation demonstrated an increase in acetylcholine receptors as well as large quantities of neuromuscular junctions both in vitro and in vivo (Ko et al. 2013). In addition to chemical stimulation, co-culturing muscle and neural cells was also studied as a method to enhance innervation of muscle constructs (Morimoto et al. 2013; Cvetkovic et al. 2017; Happe et al. 2017; Martin et al. 2015; Larkin et al. 2006). In one such study, Morimoto and colleagues reported on a technique to co-culture mouse muscle bundles with neural stem cells that were further differentiated into motor neurons (Morimoto et al. 2013). This coculture system enabled formation of neuromuscular junctions and muscle contraction following chemical stimulation (Morimoto et al. 2013).

Human iPSC-derived neural and muscle cells have similarly been co-cultured in $3 \mathrm{D}$, reportedly enabling maturation of neuromuscular junctions by such technique (Osaki et al. 2018b; Afshar Bakooshli et al. 2019; Maffioletti et al. 2018). In a recent study, innervated skeletal muscle constructs have been generated by co-culturing human muscle progenitors cells and pluripotent stem cell-derived motor neurons inside a fibrin/Geltrex hydrogel (Afshar Bakooshli et al. 2019). Following 2 weeks of culture, motor neuron clusters were detected at the periphery of the newly formed muscle bundles (Afshar Bakooshli et al. 2019). Importantly, an epsilon acetylcholine receptor subunit, indicative of adult synapse formation, was detected in the newly formed neuromuscular junctions in 3D but not in a 2D co-culture system (Afshar Bakooshli et al. 2019). In line with these results, the authors detected calcium transits in response to motor neuron stimulation in the fibers, which suggests functional innervation (Afshar Bakooshli et al. 2019). Collectively, these results highlight the importance of 3D co-culture systems for production of functional neuromuscular junctions in vitro.

\subsection{Integrative Tissue Engineering Approaches to Treat VML}

The extent by which current therapeutic interventions assist in treating VML in humans is still not completely understood. However, a recently published large-scale meta-analysis comparing different VML regenerative medicine-based treatment 
options in animal models concluded that interventions improve functional recovery in comparison to untreated injury (Greising et al. 2019). Importantly, of all examined interventions, delivery of acellular biomaterials seeded with cells was deemed the most beneficial therapeutic approach (Greising et al. 2019). However, previous works have revealed the potential of ECM based-scaffolds to treat VML. Acellular scaffolds alone have been implanted in rodents and humans to counteract VML; however, these constructs solely depend on infiltration of host cells, which presents a challenge (Greising et al. 2019; Sicari et al. 2014; Dziki et al. 2016; Corona and Greising 2016). An alternative approach is engineering skeletal muscle constructs in vitro for the treatment of VML or late stage DMD. Notably, success of this approach depends on integration of different techniques and approaches, such as combining different cell types with various biomaterials. Such an approach involves selection of an appropriate biomaterial, the type of muscle precursor cell to utilize, as well as methods to innervate and vascularize the muscle constructs. In the last section, we will introduce several studies that successfully assimilated different techniques to produce engineered skeletal muscle tissue constructs in vitro that further demonstrated functional therapeutic outcome in vivo.

A powerful approach to engineer muscle tissue involves combination of acellular scaffolds with live cells prior to implantation, thus circumventing the dependency on host cell-infiltration. Therapeutic applicability of this approach has been successfully investigated in rodent VML models (Mintz et al. 2019; Quarta et al. 2017; Nakayama et al. 2019). In one recent study, engineered muscle bundles have been created from adult rat myogenic cells seeded with bone marrow-derived macrophages, an essential cellular component for muscle regeneration (Novak et al. 2014; Bencze et al. 2012; Lesault et al. 2012; Juhas et al. 2018). The incorporation of macrophages into engineered muscle constructs was deemed a critical step following cardiotoxin injury in vitro, enabling extensive structural and functional tissue repair (Juhas et al. 2018).

Directed differentiation of iPSCs is an elegant approach to produce muscle cells or other cell types that comprise skeletal muscle tissue. Indeed, a few recent studies reported on new disease models for muscular dystrophies using iPSC-derived muscle cells (Long et al. 2018; Maffioletti et al. 2018). In one notable study, Maffioletti and colleagues cultured human iPSC-derived muscle progenitors together with endothelial cells and pericytes inside a fibrin hydrogel, demonstrating formation of vessel-like structures inside muscle bundles (Maffioletti et al. 2018). Furthermore, iPSC-derived neural precursors were incorporated into these engineered muscle bundles and gave rise to motor neurons (Maffioletti et al. 2018). This artificial skeletal muscle tissue-like construct consist of multiple human iPSC-derived cell types that conjunctionally mimic physiological muscle tissue, offering an elegant platform for disease modeling or a tissue source to treat VML lesions (Maffioletti et al. 2018).

A growing number of new studies have unearthed the roles of muscle resident cells (MRCs) in mediating skeletal muscle tissue regeneration and repair (Wosczyna and Rando 2018). In a recent elegant study, Quarta and colleagues assessed the MRCs capacity to assist engineered muscle constructs in repairing VML lesions in a 
mouse model(Quarta et al. 2017). As first step, freshly isolated satellite cells were suspended in collagen I or ECM hydrogel solutions and seeded onto decellularized muscle scaffolds (Quarta et al. 2017). To test the effects of MRCs on muscle regeneration, FACS-purified MRCs including hematopoietic, endothelial, fibroadipogenic, and fibroblast-like cells were coalesced with muscle stem cells and engineered muscle constructs and further delivered into VML lesions (Quarta et al. 2017). Remarkably, combination of muscle stem cells and MRCs dramatically increased the regeneration potential of the engrafted constructs, culminating in increased muscle mass and force production of treated lesions compared to control mice treated with constructs consisting of muscle stem cells alone (Quarta et al. 2017). Moreover, this bioconstructs restored biomechanical properties in a murine model of VML and reduced fibrosis (Quarta et al. 2018). Lastly the potential of running exercise to assist in the regeneration process was further assessed, demonstrating improved innervation of the muscle constructs in lesions, which facilitated functional recovery of treated mice (Quarta et al. 2017). It will be of interest to further delineate the molecular mechanisms that enable exercise to potentiate muscle regeneration in this model and whether it can be harnessed to assist other engraftment paradigms such as stem cell delivery into dystrophic muscles.

Reconstructing skeletal muscle tissue in vitro is a formidable feat that involves a plethora of cellular and acellular components as well as engineering techniques. The breadth of recent research in the tissue engineering field is spearheading efforts to achieve this goal. Novel approaches to grow cells on scaffolds or hydrogels, improved methods to vascularize or innervate engineered tissues as well as harnessing muscle resident cells for repair streamline novel assistive means to engineer muscle tissue. This melting pot of different techniques and approaches is expected to yield new therapeutic applications to treat VML and other muscleassociated diseases.

\section{Conclusions}

Healthy skeletal muscle tissue harbors a prodigious regenerative capacity to restore muscle loss during injury or disease states. However, this capability is often derailed in patients with severe pathological conditions such as muscular dystrophies, sarcopenia, cachexia, and VML. Intramuscular transplantation of muscle stem or progenitor cells provides an attractive approach to treat some of the aforementioned conditions, albeit significant challenges still inhibit use of this approach in clinical settings. Notably, for therapeutic interventions to succeed, it will be imperative to formulate methods to match a treatment to a specific disease condition, while taking into consideration the severity grade of the affliction. For example, muscle stem cells are expected to engraft better when delivered into early-stage dystrophic muscles which contain sufficient amount of myofibers that could enable donor-derived cells to engraft. Contrastingly, late-stage DMD and VML is characterized by extensive muscle lesions and replacement with fibrotic or adipogenic tissues, rendering muscle stem cell transplantation futile in the absence of sufficient muscle volume. In such 
occurrences, incorporation of 3D tissue-engineered skeletal muscle constructs could provide a more valuable therapeutic method to restore muscle mass.

An additional important criterion to consider for cell replacement therapy is the choice of engrafted cells. To date, a majority of research studies have focused primarily on relatively undefined myoblast cultures for human transplantation. Rapid advances in isolation and ex vivo culture of human satellite cells could provide a superior cell source for engraftment, thus allowing a long-term therapeutic effect. It is therefore of interest to assess whether direct injection of freshly isolated satellite cells, or in vitro expanded satellite-like cells, could promote dystrophin restoration and potential recovery in DMD patient's muscles. Building upon decades of myoblast transplantation trials in humans can lend useful insights when embarking on such new translational endeavors and assist in overcoming current translational roadblocks. Moreover, novel studies have also recently illustrated ways to generate unlimited number of therapeutically applicable myogenic precursors, either from PSCs or by direct reprogramming of somatic cells. It is of interest to further investigate these new conversion paradigms and compare the generated myogenic precursors molecularly and functionally to satellite cells and myoblasts. Such comparison could assist in finding the most suitable cell type for therapeutic applications.

Lastly, the role of muscle resident cells in mediating muscle tissue repair has been increasingly elucidated in recent years. Single cell sequencing technologies have helped map the various cell types that comprise muscle tissue, shedding new light on the cellular and molecular pathways involved in muscle regeneration. From a translational perspective, it will be of interest to investigate in detail whether injections of MRCs with muscle stem cells could better alleviate dystrophic symptoms and increase therapeutic outcomes in animal models. It is foreseeable that regenerating a patient's dystrophic muscles may require injections of three to five different cell types, each carrying a unique role in mediating tissue repair. Further research is also warranted in respect to tissue engineering of bioconstructs by incorporating MRCs and muscle stem cells. The majority of research to date has incorporated myoblasts into muscle constructs, whereas recent work nicely implemented muscles stem cells and MRCs to achieve muscle regeneration utilizing tissue-like constructs. Transplantation of an in vitro engineered muscle-like tissue that harbors satellite cell niches and consists of multiple cell types could provide a promising treatment strategy for patients suffering from VML or late-stage muscular dystrophies.

In conclusion, muscle-associated diseases inflict tremendous burden and pain on patients, their families, and society. New research in stem cell biology, biomaterials and tissue engineering immensely elevates our ability to remedy degenerative muscle tissue, bringing new hope for novel therapeutic treatments. It is anticipated that a synergistic approach combining different disciplines and assimilating various techniques will provide the most suitable way for achieving this goal.

Acknowledgments We wish to thank Dr. Ines Soro Arnáiz and Dr. Gommaar D’Hulst as well as all members of the Regenerative and Movement Biology laboratory for their constructive comments 
and feedback. We are further grateful to Dr. Shahragim Tajbakhsh for providing the Pax7-nGFP mouse strain and Xhem Qabrati, Inseon Kim and Ajda Lenardic for the Pax7-nGFP myoblasts, iMPCs and iPSC-derived MPCs.

\section{References}

Afshar Bakooshli M, Lippmann ES, Mulcahy B, Iyer N, Nguyen CT, Tung K, Stewart BA, van den Dorpel H, Fuehrmann T, Shoichet M, Bigot A, Pegoraro E, Ahn H, Ginsberg H, Zhen M, Ashton RS, Gilbert PM (2019) A 3D culture model of innervated human skeletal muscle enables studies of the adult neuromuscular junction. Elife 8. https://doi.org/10.7554/eLife.44530

Aguado BA, Mulyasasmita W, Su J, Lampe KJ, Heilshorn SC (2012) Improving viability of stem cells during syringe needle flow through the design of hydrogel cell carriers. Tissue Eng Part A 18(7-8):806-815. https://doi.org/10.1089/ten.TEA.2011.0391

Alexander MS, Rozkalne A, Colletta A, Spinazzola JM, Johnson S, Rahimov F, Meng H, Lawlor MW, Estrella E, Kunkel LM, Gussoni E (2016) CD82 is a marker for prospective isolation of human muscle satellite cells and is linked to muscular dystrophies. Cell Stem Cell 19(6):800807. https://doi.org/10.1016/j.stem.2016.08.006

Alter J, Rozentzweig D, Bengal E (2008) Inhibition of myoblast differentiation by tumor necrosis factor alpha is mediated by c-Jun N-terminal kinase 1 and leukemia inhibitory factor. J Biol Chem 283(34):23224-23234. https://doi.org/10.1074/jbc.M801379200

Arnett AL, Konieczny P, Ramos JN, Hall J, Odom G, Yablonka-Reuveni Z, Chamberlain JR, Chamberlain JS (2014) Adeno-associated viral (AAV) vectors do not efficiently target muscle satellite cells. Mol Ther Methods Clin Dev 1. https://doi.org/10.1038/mtm.2014.38

Austin L, Burgess AW (1991) Stimulation of myoblast proliferation in culture by leukaemia inhibitory factor and other cytokines. J Neurol Sci 101(2):193-197. https://doi.org/10.1016/ 0022-510x(91)90045-9

Austin L, Bower J, Kurek J, Vakakis N (1992) Effects of leukaemia inhibitory factor and other cytokines on murine and human myoblast proliferation. J Neurol Sci 112(1-2):185-191. https:// doi.org/10.1016/0022-510x(92)90149-f

Baghdadi MB, Castel D, Machado L, Fukada SI, Birk DE, Relaix F, Tajbakhsh S, Mourikis P (2018) Reciprocal signalling by Notch-Collagen V-CALCR retains muscle stem cells in their niche. Nature 557(7707):714-718. https://doi.org/10.1038/s41586-018-0144-9

Bansal V, De D, An J, Kang TM, Jeong HJ, Kang JS, Kim KK (2019) Chemical induced conversion of mouse fibroblasts and human adipose-derived stem cells into skeletal muscle-like cells. Biomaterials 193:30-46. https://doi.org/10.1016/j.biomaterials.2018.11.037

Baracos VE, Martin L, Korc M, Guttridge DC, Fearon KCH (2018) Cancer-associated cachexia. Nat Rev Dis Primers 4:17105. https://doi.org/10.1038/nrdp.2017.105

Barberi T, Bradbury M, Dincer Z, Panagiotakos G, Socci ND, Studer L (2007) Derivation of engraftable skeletal myoblasts from human embryonic stem cells. Nat Med 13(5):642-648. https://doi.org/10.1038/nm1533

Bar-Nur O, Gerli MFM, Di Stefano B, Almada AE, Galvin A, Coffey A, Huebner AJ, Feige P, Verheul C, Cheung P, Payzin-Dogru D, Paisant S, Anselmo A, Sadreyev RI, Ott HC, Tajbakhsh S, Rudnicki MA, Wagers AJ, Hochedlinger K (2018) Direct reprogramming of mouse fibroblasts into functional skeletal muscle progenitors. Stem Cell Reports 10(5):1505-1521. https:// doi.org/10.1016/j.stemcr.2018.04.009

Beauchamp JR, Morgan JE, Pagel CN, Partridge TA (1999) Dynamics of myoblast transplantation reveal a discrete minority of precursors with stem cell-like properties as the myogenic source. $\mathrm{J}$ Cell Biol 144(6):1113-1122. https://doi.org/10.1083/jcb.144.6.1113

Beauchamp JR, Heslop L, Yu DS, Tajbakhsh S, Kelly RG, Wernig A, Buckingham ME, Partridge TA, Zammit PS (2000) Expression of CD34 and Myf5 defines the majority of quiescent adult skeletal muscle satellite cells. J Cell Biol 151(6):1221-1234. https://doi.org/10.1083/ jcb.151.6.1221 
Bencze M, Negroni E, Vallese D, Yacoub-Youssef H, Chaouch S, Wolff A, Aamiri A, Di Santo JP, Chazaud B, Butler-Browne G, Savino W, Mouly V, Riederer I (2012) Proinflammatory macrophages enhance the regenerative capacity of human myoblasts by modifying their kinetics of proliferation and differentiation. Mol Ther 20(11):2168-2179. https://doi.org/10.1038/ mt.2012.189

Ben-David U, Benvenisty N (2011) The tumorigenicity of human embryonic and induced pluripotent stem cells. Nat Rev Cancer 11(4):268-277. https://doi.org/10.1038/nrc3034

Bentzinger CF, Barzaghi P, Lin S, Ruegg MA (2005) Overexpression of mini-agrin in skeletal muscle increases muscle integrity and regenerative capacity in laminin-alpha2-deficient mice. FASEB J 19(8):934-942. https://doi.org/10.1096/fj.04-3376com

Bentzinger CF, Wang YX, von Maltzahn J, Soleimani VD, Yin H, Rudnicki MA (2013) Fibronectin regulates Wnt7a signaling and satellite cell expansion. Cell Stem Cell 12(1):75-87. https://doi. org/10.1016/j.stem.2012.09.015

Bentzinger CF, von Maltzahn J, Dumont NA, Stark DA, Wang YX, Nhan K, Frenette J, Cornelison DD, Rudnicki MA (2014) Wnt7a stimulates myogenic stem cell motility and engraftment resulting in improved muscle strength. J Cell Biol 205(1):97-111. https://doi.org/10.1083/ jcb.201310035

Bernet JD, Doles JD, Hall JK, Kelly Tanaka K, Carter TA, Olwin BB (2014) p38 MAPK signaling underlies a cell-autonomous loss of stem cell self-renewal in skeletal muscle of aged mice. Nat Med 20(3):265-271. https://doi.org/10.1038/nm.3465

Bezakova G, Ruegg MA (2003) New insights into the roles of agrin. Nat Rev Mol Cell Biol 4 (4):295-308. https://doi.org/10.1038/nrm1074

Bian W, Bursac N (2012) Soluble miniagrin enhances contractile function of engineered skeletal muscle. FASEB J 26(2):955-965. https://doi.org/10.1096/fj.11-187575

Bian W, Liau B, Badie N, Bursac N (2009) Mesoscopic hydrogel molding to control the 3D geometry of bioartificial muscle tissues. Nat Protoc 4(10):1522-1534. https://doi.org/10.1038/ nprot.2009.155

Bisson A, Freret M, Drouot L, Jean L, Le Corre S, Gourcerol G, Doucet C, Michot F, Boyer O, Lamacz M (2015) Restoration of anal sphincter function after myoblast cell therapy in incontinent rats. Cell Transplant 24(2):277-286. https://doi.org/10.3727/096368913X674053

Bjornson CR, Cheung TH, Liu L, Tripathi PV, Steeper KM, Rando TA (2012) Notch signaling is necessary to maintain quiescence in adult muscle stem cells. Stem Cells 30(2):232-242. https:// doi.org/10.1002/stem.773

Blaganje M, Lukanovic A (2012) Intrasphincteric autologous myoblast injections with electrical stimulation for stress urinary incontinence. Int J Gynaecol Obstet 117(2):164-167. https://doi. org/10.1016/j.ijgo.2011.11.029

Blau HM, Daley GQ (2019) Stem cells in the treatment of disease. N Engl J Med 380(18):17481760. https://doi.org/10.1056/NEJMra1716145

Boldrin L, Elvassore N, Malerba A, Flaibani M, Cimetta E, Piccoli M, Baroni MD, Gazzola MV, Messina C, Gamba P, Vitiello L, De Coppi P (2007) Satellite cells delivered by micro-patterned scaffolds: a new strategy for cell transplantation in muscle diseases. Tissue Eng 13(2):253-262. https://doi.org/10.1089/ten.2006.0093

Boldrin L, Malerba A, Vitiello L, Cimetta E, Piccoli M, Messina C, Gamba PG, Elvassore N, De Coppi $\mathrm{P}$ (2008) Efficient delivery of human single fiber-derived muscle precursor cells via biocompatible scaffold. Cell Transplant 17(5):577-584. https://doi.org/10.3727/096368908785095980

Boonen KJ, Rosaria-Chak KY, Baaijens FP, van der Schaft DW, Post MJ (2009) Essential environmental cues from the satellite cell niche: optimizing proliferation and differentiation. Am J Physiol Cell Physiol 296(6):C1338-C1345. https://doi.org/10.1152/ajpcell.00015.2009

Borchin B, Chen J, Barberi T (2013) Derivation and FACS-mediated purification of PAX3+/PAX7+ skeletal muscle precursors from human pluripotent stem cells. Stem Cell Reports 1(6):620-631. https://doi.org/10.1016/j.stemcr.2013.10.007

Borselli C, Storrie H, Benesch-Lee F, Shvartsman D, Cezar C, Lichtman JW, Vandenburgh HH, Mooney DJ (2010) Functional muscle regeneration with combined delivery of angiogenesis and 
myogenesis factors. Proc Natl Acad Sci U S A 107(8):3287-3292. https://doi.org/10.1073/ pnas.0903875106

Borselli C, Cezar CA, Shvartsman D, Vandenburgh HH, Mooney DJ (2011) The role of multifunctional delivery scaffold in the ability of cultured myoblasts to promote muscle regeneration. Biomaterials 32(34):8905-8914. https://doi.org/10.1016/j.biomaterials.2011.08.019

Bosnakovski D, Xu Z, Li W, Thet S, Cleaver O, Perlingeiro RC, Kyba M (2008) Prospective isolation of skeletal muscle stem cells with a Pax7 reporter. Stem Cells 26(12):3194-3204. https://doi.org/10.1634/stemcells.2007-1017

Boyer O, Bridoux V, Giverne C, Bisson A, Koning E, Leroi AM, Chambon P, Dehayes J, Le Corre S, Jacquot S, Bastit D, Martinet J, Houivet E, Tuech JJ, Benichou J, Michot F, The Study Group of Myoblast Therapy for Faecal I (2018) Autologous myoblasts for the treatment of fecal incontinence: results of a phase 2 randomized placebo-controlled study (MIAS). Ann Surg 267(3):443-450. https://doi.org/10.1097/SLA.0000000000002268

Brais B, Bouchard JP, Xie YG, Rochefort DL, Chretien N, Tome FM, Lafreniere RG, Rommens JM, Uyama E, Nohira O, Blumen S, Korczyn AD, Heutink P, Mathieu J, Duranceau A, Codere F, Fardeau M, Rouleau GA (1998) Short GCG expansions in the PABP2 gene cause oculopharyngeal muscular dystrophy. Nat Genet 18(2):164-167. https://doi.org/10.1038/ ng0298-164

Briggs D, Morgan JE (2013) Recent progress in satellite cell/myoblast engraftment - relevance for therapy. FEBS J 280(17):4281-4293. https://doi.org/10.1111/febs.12273

Brohl D, Vasyutina E, Czajkowski MT, Griger J, Rassek C, Rahn HP, Purfurst B, Wende H, Birchmeier C (2012) Colonization of the satellite cell niche by skeletal muscle progenitor cells depends on Notch signals. Dev Cell 23(3):469-481. https://doi.org/10.1016/j.devcel.2012.07.014

Castiglioni A, Hettmer S, Lynes MD, Rao TN, Tchessalova D, Sinha I, Lee BT, Tseng YH, Wagers AJ (2014) Isolation of progenitors that exhibit myogenic/osteogenic bipotency in vitro by fluorescence-activated cell sorting from human fetal muscle. Stem Cell Reports 2(1):92-106. https://doi.org/10.1016/j.stemcr.2013.12.006

Cerletti M, Jurga S, Witczak CA, Hirshman MF, Shadrach JL, Goodyear LJ, Wagers AJ (2008) Highly efficient, functional engraftment of skeletal muscle stem cells in dystrophic muscles. Cell 134(1):37-47. https://doi.org/10.1016/j.cell.2008.05.049

Cezar CA, Mooney DJ (2015) Biomaterial-based delivery for skeletal muscle repair. Adv Drug Deliv Rev 84:188-197. https://doi.org/10.1016/j.addr.2014.09.008

Chal J, Pourquie O (2017) Making muscle: skeletal myogenesis in vivo and in vitro. Development 144(12):2104-2122. https://doi.org/10.1242/dev.151035

Chal J, Oginuma M, Al Tanoury Z, Gobert B, Sumara O, Hick A, Bousson F, Zidouni Y, Mursch C, Moncuquet P, Tassy O, Vincent S, Miyanari A, Bera A, Garnier JM, Guevara G, Hestin M, Kennedy L, Hayashi S, Drayton B, Cherrier T, Gayraud-Morel B, Gussoni E, Relaix F, Tajbakhsh S, Pourquie O (2015) Differentiation of pluripotent stem cells to muscle fiber to model Duchenne muscular dystrophy. Nat Biotechnol 33(9):962-969. https://doi.org/10.1038/ nbt.3297

Chal J, Al Tanoury Z, Oginuma M, Moncuquet P, Gobert B, Miyanari A, Tassy O, Guevara G, Hubaud A, Bera A, Sumara O, Garnier JM, Kennedy L, Knockaert M, Gayraud-Morel B, Tajbakhsh S, Pourquie O (2018) Recapitulating early development of mouse musculoskeletal precursors of the paraxial mesoderm in vitro. Development 145(6). https://doi.org/10.1242/ dev. 157339

Chan SS, Arpke RW, Filareto A, Xie N, Pappas MP, Penaloza JS, Perlingeiro RCR, Kyba M (2018) Skeletal muscle stem cells from PSC-derived teratomas have functional regenerative capacity. Cell Stem Cell 23(1):74-85 e76. https://doi.org/10.1016/j.stem.2018.06.010

Chang H, Hwang S, Lim S, Eo S, Minn KW, Hong KY (2018) Long-term fate of denervated skeletal muscle after microvascular flap transfer. Ann Plast Surg 80(6):644-647. https://doi.org/ 10.1097/SAP.0000000000001397 
Charville GW, Cheung TH, Yoo B, Santos PJ, Lee GK, Shrager JB, Rando TA (2015) Ex vivo expansion and in vivo self-renewal of human muscle stem cells. Stem Cell Reports 5(4):621632. https://doi.org/10.1016/j.stemcr.2015.08.004

Chen AE, Ginty DD, Fan CM (2005) Protein kinase A signalling via CREB controls myogenesis induced by Wnt proteins. Nature 433(7023):317-322. https://doi.org/10.1038/nature03126

Choi IY, Lim H, Estrellas K, Mula J, Cohen TV, Zhang Y, Donnelly CJ, Richard JP, Kim YJ, Kim H, Kazuki Y, Oshimura M, Li HL, Hotta A, Rothstein J, Maragakis N, Wagner KR, Lee G (2016) Concordant but varied phenotypes among duchenne muscular dystrophy patient-specific myoblasts derived using a human iPSC-based model. Cell Rep 15(10):2301-2312. https://doi.org/ 10.1016/j.celrep.2016.05.016

Collins CA, Olsen I, Zammit PS, Heslop L, Petrie A, Partridge TA, Morgan JE (2005) Stem cell function, self-renewal, and behavioral heterogeneity of cells from the adult muscle satellite cell niche. Cell 122(2):289-301. https://doi.org/10.1016/j.cell.2005.05.010

Colognato H, Yurchenco PD (2000) Form and function: the laminin family of heterotrimers. Dev Dyn 218(2):213-234. https://doi.org/10.1002/(SICI)1097-0177(200006)218:2<213::AIDDVDY1>3.0.CO;2-R

Comai G, Tajbakhsh S (2014) Molecular and cellular regulation of skeletal myogenesis. Curr Top Dev Biol 110:1-73. https://doi.org/10.1016/B978-0-12-405943-6.00001-4

Conboy IM, Rando TA (2002) The regulation of Notch signaling controls satellite cell activation and cell fate determination in postnatal myogenesis. Dev Cell 3(3):397-409. https://doi.org/ 10.1016/s1534-5807(02)00254-x

Corona BT, Greising SM (2016) Challenges to acellular biological scaffold mediated skeletal muscle tissue regeneration. Biomaterials 104:238-246. https://doi.org/10.1016/j.biomaterials.2016.07.020

Corona BT, Ward CL, Baker HB, Walters TJ, Christ GJ (2014) Implantation of in vitro tissue engineered muscle repair constructs and bladder acellular matrices partially restore in vivo skeletal muscle function in a rat model of volumetric muscle loss injury. Tissue Eng Part A 20 (3-4):705-715. https://doi.org/10.1089/ten.TEA.2012.0761

Corona BT, Wenke JC, Ward CL (2016) Pathophysiology of volumetric muscle loss injury. Cells Tissues Organs 202(3-4):180-188. https://doi.org/10.1159/000443925

Corona BT, Rivera JC, Dalske KA, Wenke JC, Greising SM (2019) Pharmacological mitigation of fibrosis in a porcine model of volumetric muscle loss injury. Tissue Eng Part A. https://doi.org/ 10.1089/ten.TEA.2019.0272

Cosgrove BD, Gilbert PM, Porpiglia E, Mourkioti F, Lee SP, Corbel SY, Llewellyn ME, Delp SL, Blau HM (2014) Rejuvenation of the muscle stem cell population restores strength to injured aged muscles. Nat Med 20(3):255-264. https://doi.org/10.1038/nm.3464

Cossu G, Previtali SC, Napolitano S, Cicalese MP, Tedesco FS, Nicastro F, Noviello M, Roostalu U, Natali Sora MG, Scarlato M, De Pellegrin M, Godi C, Giuliani S, Ciotti F, Tonlorenzi R, Lorenzetti I, Rivellini C, Benedetti S, Gatti R, Marktel S, Mazzi B, Tettamanti A, Ragazzi M, Imro MA, Marano G, Ambrosi A, Fiori R, Sormani MP, Bonini C, Venturini M, Politi LS, Torrente Y, Ciceri F (2015) Intra-arterial transplantation of HLA-matched donor mesoangioblasts in Duchenne muscular dystrophy. EMBO Mol Med 7(12):1513-1528. https://doi. org/10.15252/emmm.201505636

Costantini M, Testa S, Mozetic P, Barbetta A, Fuoco C, Fornetti E, Tamiro F, Bernardini S, Jaroszewicz J, Swieszkowski W, Trombetta M, Castagnoli L, Seliktar D, Garstecki P, Cesareni G, Cannata S, Rainer A, Gargioli C (2017) Microfluidic-enhanced 3D bioprinting of aligned myoblast-laden hydrogels leads to functionally organized myofibers in vitro and in vivo. Biomaterials 131:98-110. https://doi.org/10.1016/j.biomaterials.2017.03.026

Cvetkovic C, Rich MH, Raman R, Kong H, Bashir R (2017) A 3D-printed platform for modular neuromuscular motor units. Microsyst Nanoeng 3:17015. https://doi.org/10.1038/ micronano.2017.15

da Cruz L, Fynes K, Georgiadis O, Kerby J, Luo YH, Ahmado A, Vernon A, Daniels JT, Nommiste B, Hasan SM, Gooljar SB, Carr AF, Vugler A, Ramsden CM, Bictash M, Fenster M, Steer J, Harbinson T, Wilbrey A, Tufail A, Feng G, Whitlock M, Robson AG, Holder GE, Sagoo MS, 
Loudon PT, Whiting P, Coffey PJ (2018) Phase 1 clinical study of an embryonic stem cellderived retinal pigment epithelium patch in age-related macular degeneration. Nat Biotechnol 36(4):328-337. https://doi.org/10.1038/nbt.4114

Darabi R, Gehlbach K, Bachoo RM, Kamath S, Osawa M, Kamm KE, Kyba M, Perlingeiro RC (2008) Functional skeletal muscle regeneration from differentiating embryonic stem cells. Nat Med 14(2):134-143. https://doi.org/10.1038/nm1705

Darabi R, Santos FN, Filareto A, Pan W, Koene R, Rudnicki MA, Kyba M, Perlingeiro RC (2011) Assessment of the myogenic stem cell compartment following transplantation of Pax3/Pax7induced embryonic stem cell-derived progenitors. Stem Cells 29(5):777-790. https://doi.org/ 10.1002/stem.625

Darabi R, Arpke RW, Irion S, Dimos JT, Grskovic M, Kyba M, Perlingeiro RC (2012) Human ESand iPS-derived myogenic progenitors restore DYSTROPHIN and improve contractility upon transplantation in dystrophic mice. Cell Stem Cell 10(5):610-619. https://doi.org/10.1016/j. stem.2012.02.015

Davis RL, Weintraub H, Lassar AB (1987) Expression of a single transfected cDNA converts fibroblasts to myoblasts. Cell 51(6):987-1000

Davoudi S, Chin CY, Cooke MJ, Tam RY, Shoichet MS, Gilbert PM (2018) Muscle stem cell intramuscular delivery within hyaluronan methylcellulose improves engraftment efficiency and dispersion. Biomaterials 173:34-46. https://doi.org/10.1016/j.biomaterials.2018.04.048

De Micheli AJ, Laurilliard EJ, Heinke CL, Ravichandran H, Fraczek P, Soueid-Baumgarten S, De Vlaminck I, Elemento O, Cosgrove BD (2020) Single-cell analysis of the muscle stem cell hierarchy identifies heterotypic communication signals involved in skeletal muscle regeneration. Cell Rep 30(10):3583-3595 e3585. https://doi.org/10.1016/j.celrep.2020.02.067

Dekel I, Magal Y, Pearson-White S, Emerson CP, Shani M (1992) Conditional conversion of ES cells to skeletal muscle by an exogenous MyoD1 gene. New Biol 4(3):217-224

Del Carmen Ortuno-Costela M, Garcia-Lopez M, Cerrada V, Gallardo ME (2019) iPSCs: a powerful tool for skeletal muscle tissue engineering. J Cell Mol Med 23(6):3784-3794. https://doi.org/10.1111/jcmm.14292

Dell'Orso S, Juan AH, Ko KD, Naz F, Perovanovic J, Gutierrez-Cruz G, Feng X, Sartorelli V (2019) Single cell analysis of adult mouse skeletal muscle stem cells in homeostatic and regenerative conditions. Development 146(12). https://doi.org/10.1242/dev.174177

Dennison EM, Sayer AA, Cooper C (2017) Epidemiology of sarcopenia and insight into possible therapeutic targets. Nat Rev Rheumatol 13(6):340-347. https://doi.org/10.1038/ nrrheum. 2017.60

Dhawan V, Lytle IF, Dow DE, Huang YC, Brown DL (2007) Neurotization improves contractile forces of tissue-engineered skeletal muscle. Tissue Eng 13(11):2813-2821. https://doi.org/ $10.1089 /$ ten.2007.0003

Ding S, Swennen GNM, Messmer T, Gagliardi M, Molin DGM, Li C, Zhou G, Post MJ (2018) Maintaining bovine satellite cells stemness through p38 pathway. Sci Rep 8(1):10808. https:// doi.org/10.1038/s41598-018-28746-7

Doudna JA, Charpentier E (2014) Genome editing. The new frontier of genome engineering with CRISPR-Cas9. Science 346(6213):1258096. https://doi.org/10.1126/science.1258096

Duffy RM, Sun Y, Feinberg AW (2016) Understanding the role of ECM protein composition and geometric micropatterning for engineering human skeletal muscle. Ann Biomed Eng 44 (6):2076-2089. https://doi.org/10.1007/s10439-016-1592-8

Dumont NA, Rudnicki MA (2017) Characterizing satellite cells and myogenic progenitors during skeletal muscle regeneration. Methods Mol Biol 1560:179-188. https://doi.org/10.1007/978-14939-6788-9_12

Dumont NA, Wang YX, von Maltzahn J, Pasut A, Bentzinger CF, Brun CE, Rudnicki MA (2015) Dystrophin expression in muscle stem cells regulates their polarity and asymmetric division. Nat Med 21(12):1455-1463. https://doi.org/10.1038/nm.3990

Duranceau A, Forand MD, Fauteux JP (1980) Surgery in oculopharyngeal muscular dystrophy. Am J Surg 139(1):33-39. https://doi.org/10.1016/0002-9610(80)90226-3 
Dziki J, Badylak S, Yabroudi M, Sicari B, Ambrosio F, Stearns K, Turner N, Wyse A, Boninger ML, Brown EHP, Rubin JP (2016) An acellular biologic scaffold treatment for volumetric muscle loss: results of a 13-patient cohort study. NPJ Regen Med 1:16008. https://doi.org/ 10.1038/npjregenmed.2016.8

Eberli D, Aboushwareb T, Soker S, Yoo JJ, Atala A (2012) Muscle precursor cells for the restoration of irreversibly damaged sphincter function. Cell Transplant 21(9):2089-2098. https://doi.org/10.3727/096368911X623835

Eliazer S, Muncie JM, Christensen J, Sun X, D’Urso RS, Weaver VM, Brack AS (2019) Wnt4 from the niche controls the mechano-properties and quiescent state of muscle stem cells. Cell Stem Cell 25(5):654-665 e654. https://doi.org/10.1016/j.stem.2019.08.007

Engler AJ, Griffin MA, Sen S, Bonnemann CG, Sweeney HL, Discher DE (2004) Myotubes differentiate optimally on substrates with tissue-like stiffness: pathological implications for soft or stiff microenvironments. J Cell Biol 166(6):877-887. https://doi.org/10.1083/ jcb.200405004

Evans MJ, Kaufman MH (1981) Establishment in culture of pluripotential cells from mouse embryos. Nature 292(5819):154-156

Fan Y, Maley M, Beilharz M, Grounds M (1996) Rapid death of injected myoblasts in myoblast transfer therapy. Muscle Nerve 19(7):853-860. https://doi.org/10.1002/(SICI)1097-4598 (199607)19:7<853::AID-MUS7>3.0.CO;2-8

Filareto A, Darabi R, Perlingeiro RC (2012) Engraftment of ES-derived myogenic progenitors in a severe mouse model of muscular dystrophy. J Stem Cell Res Ther 10(1). https://doi.org/ 10.4172/2157-7633.S10-001

Filareto A, Parker S, Darabi R, Borges L, Iacovino M, Schaaf T, Mayerhofer T, Chamberlain JS, Ervasti JM, McIvor RS, Kyba M, Perlingeiro RC (2013) An ex vivo gene therapy approach to treat muscular dystrophy using inducible pluripotent stem cells. Nat Commun 4:1549. https:// doi.org/10.1038/ncomms 2550

Filareto A, Rinaldi F, Arpke RW, Darabi R, Belanto JJ, Toso EA, Miller AZ, Ervasti JM, McIvor RS, Kyba M, Perlingeiro RC (2015) Pax3-induced expansion enables the genetic correction of dystrophic satellite cells. Skelet Muscle 5:36. https://doi.org/10.1186/s13395-015-0061-7

Foster RF, Thompson JM, Kaufman SJ (1987) A laminin substrate promotes myogenesis in rat skeletal muscle cultures: analysis of replication and development using antidesmin and antiBrdUrd monoclonal antibodies. Dev Biol 122(1):11-20. https://doi.org/10.1016/0012-1606(87) 90327-7

Frudinger A, Pfeifer J, Paede J, Kolovetsiou-Kreiner V, Marksteiner R, Halligan S (2015) Autologous skeletal-muscle-derived cell injection for anal incontinence due to obstetric trauma: a 5year follow-up of an initial study of 10 patients. Colorectal Dis 17(9):794-801. https://doi.org/ 10.1111/codi. 12947

Fu X, Xiao J, Wei Y, Li S, Liu Y, Yin J, Sun K, Sun H, Wang H, Zhang Z, Zhang BT, Sheng C, Wang H, Hu P (2015) Combination of inflammation-related cytokines promotes long-term muscle stem cell expansion. Cell Res 25(6):655-673. https://doi.org/10.1038/cr.2015.58

Fukada S, Higuchi S, Segawa M, Koda K, Yamamoto Y, Tsujikawa K, Kohama Y, Uezumi A, Imamura M, Miyagoe-Suzuki Y, Takeda S, Yamamoto H (2004) Purification and cell-surface marker characterization of quiescent satellite cells from murine skeletal muscle by a novel monoclonal antibody. Exp Cell Res 296(2):245-255. https://doi.org/10.1016/j.yexcr.2004.02.018

Fuoco C, Salvatori ML, Biondo A, Shapira-Schweitzer K, Santoleri S, Antonini S, Bernardini S, Tedesco FS, Cannata S, Seliktar D, Cossu G, Gargioli C (2012) Injectable polyethylene glycolfibrinogen hydrogel adjuvant improves survival and differentiation of transplanted mesoangioblasts in acute and chronic skeletal-muscle degeneration. Skelet Muscle 2(1):24. https:// doi.org/10.1186/2044-5040-2-24

Fuoco C, Sangalli E, Vono R, Testa S, Sacchetti B, Latronico MV, Bernardini S, Madeddu P, Cesareni G, Seliktar D, Rizzi R, Bearzi C, Cannata SM, Spinetti G, Gargioli C (2014) 3D hydrogel environment rejuvenates aged pericytes for skeletal muscle tissue engineering. Front Physiol 5:203. https://doi.org/10.3389/fphys.2014.00203 
Fuoco C, Rizzi R, Biondo A, Longa E, Mascaro A, Shapira-Schweitzer K, Kossovar O, Benedetti S, Salvatori ML, Santoleri S, Testa S, Bernardini S, Bottinelli R, Bearzi C, Cannata SM, Seliktar D, Cossu G, Gargioli C (2015) In vivo generation of a mature and functional artificial skeletal muscle. EMBO Mol Med 7(4):411-422. https://doi.org/10.15252/emmm.201404062

Garcia AJ, Vega MD, Boettiger D (1999) Modulation of cell proliferation and differentiation through substrate-dependent changes in fibronectin conformation. Mol Biol Cell 10(3):785798. https://doi.org/10.1091/mbc. 10.3 .785

Garcia SM, Tamaki S, Lee S, Wong A, Jose A, Dreux J, Kouklis G, Sbitany H, Seth R, Knott PD, Heaton C, Ryan WR, Kim EA, Hansen SL, Hoffman WY, Pomerantz JH (2018) High-yield purification, preservation, and serial transplantation of human satellite cells. Stem Cell Reports 10(3):1160-1174. https://doi.org/10.1016/j.stemcr.2018.01.022

Gardner RJ, Bobrow M, Roberts RG (1995) The identification of point mutations in Duchenne muscular dystrophy patients by using reverse-transcription PCR and the protein truncation test. Am J Hum Genet 57(2):311-320

Gerard C, Forest MA, Beauregard G, Skuk D, Tremblay JP (2012) Fibrin gel improves the survival of transplanted myoblasts. Cell Transplant 21(1):127-137. https://doi.org/10.3727/096368911 X576018

Gerli MFM, Moyle LA, Benedetti S, Ferrari G, Ucuncu E, Ragazzi M, Constantinou C, Louca I, Sakai H, Ala P, De Coppi P, Tajbakhsh S, Cossu G, Tedesco FS (2019) Combined Notch and PDGF signaling enhances migration and expression of stem cell markers while inducing perivascular cell features in muscle satellite cells. Stem Cell Reports 12(3):461-473. https:// doi.org/10.1016/j.stemcr.2019.01.007

Gholobova D, Decroix L, Van Muylder V, Desender L, Gerard M, Carpentier G, Vandenburgh H, Thorrez L (2015) Endothelial network formation within human tissue-engineered skeletal muscle. Tissue Eng Part A 21(19-20):2548-2558. https://doi.org/10.1089/ten.TEA.2015.0093

Gholobova D, Gerard M, Terrie L, Desender L, Shansky J, Vandenburgh H, Thorrez L (2019) Coculture method to obtain endothelial networks within human tissue-engineered skeletal muscle. Methods Mol Biol 1889:169-183. https://doi.org/10.1007/978-1-4939-8897-6 10

Gilbert PM, Havenstrite KL, Magnusson KE, Sacco A, Leonardi NA, Kraft P, Nguyen NK, Thrun S, Lutolf MP, Blau HM (2010) Substrate elasticity regulates skeletal muscle stem cell selfrenewal in culture. Science 329(5995):1078-1081. https://doi.org/10.1126/science.1191035

Gilbert-Honick J, Grayson W (2019) Vascularized and innervated skeletal muscle tissue engineering. Adv Healthc Mater:e1900626. https://doi.org/10.1002/adhm.201900626

Giordani L, He GJ, Negroni E, Sakai H, Law JYC, Siu MM, Wan R, Corneau A, Tajbakhsh S, Cheung TH, Le Grand F (2019) High-dimensional single-cell cartography reveals novel skeletal muscle-resident cell populations. Mol Cell 74(3):609-621 e606. https://doi.org/10.1016/j. molcel.2019.02.026

Goldstein JM, Tabebordbar M, Zhu K, Wang LD, Messemer KA, Peacker B, Ashrafi Kakhki S, Gonzalez-Celeiro M, Shwartz Y, Cheng JKW, Xiao R, Barungi T, Albright C, Hsu YC, Vandenberghe LH, Wagers AJ (2019) In situ modification of tissue stem and progenitor cell genomes. Cell Rep 27(4):1254-1264 e1257. https://doi.org/10.1016/j.celrep.2019.03.105

Goudenege S, Lebel C, Huot NB, Dufour C, Fujii I, Gekas J, Rousseau J, Tremblay JP (2012) Myoblasts derived from normal hESCs and dystrophic hiPSCs efficiently fuse with existing muscle fibers following transplantation. Mol Ther 20(11):2153-2167. https://doi.org/10.1038/ mt.2012.188

Grefte S, Vullinghs S, Kuijpers-Jagtman AM, Torensma R, Von den Hoff JW (2012) Matrigel, but not collagen I, maintains the differentiation capacity of muscle derived cells in vitro. Biomed Mater 7(5):055004. https://doi.org/10.1088/1748-6041/7/5/055004

Greising SM, Corona BT, McGann C, Frankum JK, Warren GL (2019) Therapeutic approaches for volumetric muscle loss injury: a systematic review and meta-analysis. Tissue Eng Part B Rev. https://doi.org/10.1089/ten.TEB.2019.0207 
Guerette B, Asselin I, Vilquin JT, Roy R, Tremblay JP (1995) Lymphocyte infiltration following allo- and xenomyoblast transplantation in mdx mice. Muscle Nerve 18(1):39-51. https://doi.org/ 10.1002/mus. 880180107

Gussoni E, Pavlath GK, Lanctot AM, Sharma KR, Miller RG, Steinman L, Blau HM (1992) Normal dystrophin transcripts detected in Duchenne muscular dystrophy patients after myoblast transplantation. Nature 356(6368):435-438. https://doi.org/10.1038/356435a0

Gussoni E, Blau HM, Kunkel LM (1997) The fate of individual myoblasts after transplantation into muscles of DMD patients. Nat Med 3(9):970-977. https://doi.org/10.1038/nm0997-970

Hagiwara K, Chen G, Kawazoe N, Tabata Y, Komuro H (2016) Promotion of muscle regeneration by myoblast transplantation combined with the controlled and sustained release of bFGFcpr. J Tissue Eng Regen Med 10(4):325-333. https://doi.org/10.1002/term.1732

Hall JK, Banks GB, Chamberlain JS, Olwin BB (2010) Prevention of muscle aging by myofiberassociated satellite cell transplantation. Sci Transl Med 2(57):57ra83. https://doi.org/10.1126/ scitranslmed.3001081

Han WM, Jang YC, Garcia AJ (2017) Engineered matrices for skeletal muscle satellite cell engraftment and function. Matrix Biol 60-61:96-109. https://doi.org/10.1016/j.matbio.2016.06.001

Han WM, Anderson SE, Mohiuddin M, Barros D, Nakhai SA, Shin E, Amaral IF, Pego AP, Garcia AJ, Jang YC (2018) Synthetic matrix enhances transplanted satellite cell engraftment in dystrophic and aged skeletal muscle with comorbid trauma. Sci Adv 4(8):eaar4008. https:// doi.org/10.1126/sciadv.aar4008

Han WM, Mohiuddin M, Anderson SE, Garcia AJ, Jang YC (2019) Co-delivery of Wnt7a and muscle stem cells using synthetic bioadhesive hydrogel enhances murine muscle regeneration and cell migration during engraftment. Acta Biomater 94:243-252. https://doi.org/10.1016/j. actbio.2019.06.025

Happe CL, Tenerelli KP, Gromova AK, Kolb F, Engler AJ (2017) Mechanically patterned neuromuscular junctions-in-a-dish have improved functional maturation. Mol Biol Cell 28(14):1950 1958. https://doi.org/10.1091/mbc.E17-01-0046

Hardy D, Besnard A, Latil M, Jouvion G, Briand D, Thepenier C, Pascal Q, Guguin A, GayraudMorel B, Cavaillon JM, Tajbakhsh S, Rocheteau P, Chretien F (2016) Comparative study of injury models for studying muscle regeneration in mice. PLoS One 11(1):e0147198. https://doi. org/10.1371/journal.pone.0147198

Heslop L, Beauchamp JR, Tajbakhsh S, Buckingham ME, Partridge TA, Zammit PS (2001) Transplanted primary neonatal myoblasts can give rise to functional satellite cells as identified using the Myf5nlacZl+ mouse. Gene Ther 8(10):778-783. https://doi.org/10.1038/sj. gt. 3301463

Hicks MR, Hiserodt J, Paras K, Fujiwara W, Eskin A, Jan M, Xi H, Young CS, Evseenko D, Nelson SF, Spencer MJ, Handel BV, Pyle AD (2018) ERBB3 and NGFR mark a distinct skeletal muscle progenitor cell in human development and hPSCs. Nat Cell Biol 20(1):46-57. https://doi.org/ 10.1038/s41556-017-0010-2

Hill E, Boontheekul T, Mooney DJ (2006) Regulating activation of transplanted cells controls tissue regeneration. Proc Natl Acad Sci U S A 103(8):2494-2499. https://doi.org/10.1073/ pnas. 0506004103

Hillary CJ, Roman S, MacNeil S, Aicher WK, Stenzl A, Chapple CR (2020) Regenerative medicine and injection therapies in stress urinary incontinence. Nat Rev Urol. https://doi.org/10.1038/ s41585-019-0273-4

Hirsch T, Rothoeft T, Teig N, Bauer JW, Pellegrini G, De Rosa L, Scaglione D, Reichelt J, Klausegger A, Kneisz D, Romano O, Secone Seconetti A, Contin R, Enzo E, Jurman I, Carulli S, Jacobsen F, Luecke T, Lehnhardt M, Fischer M, Kueckelhaus M, Quaglino D, Morgante M, Bicciato S, Bondanza S, De Luca M (2017) Regeneration of the entire human epidermis using transgenic stem cells. Nature 551(7680):327-332. https://doi.org/10.1038/nature24487

Hoffman EP, Brown RH Jr, Kunkel LM (1987) Dystrophin: the protein product of the Duchenne muscular dystrophy locus. Cell 51(6):919-928. https://doi.org/10.1016/0092-8674(87)90579-4 
Hong F, Lee J, Song JW, Lee SJ, Ahn H, Cho JJ, Ha J, Kim SS (2002) Cyclosporin A blocks muscle differentiation by inducing oxidative stress and inhibiting the peptidyl-prolyl-cis-trans isomerase activity of cyclophilin A: cyclophilin A protects myoblasts from cyclosporin A-induced cytotoxicity. FASEB J 16(12):1633-1635. https://doi.org/10.1096/fj.02-0060fje

Hooijmans MT, Niks EH, Burakiewicz J, Anastasopoulos C, van den Berg SI, van Zwet E, Webb AG, Verschuuren J, Kan HE (2017) Non-uniform muscle fat replacement along the proximodistal axis in Duchenne muscular dystrophy. Neuromuscul Disord 27(5):458-464. https://doi.org/10.1016/j.nmd.2017.02.009

Hu W, Wang Z, Xiao Y, Zhang S, Wang J (2019) Advances in crosslinking strategies of biomedical hydrogels. Biomater Sci 7(3):843-855. https://doi.org/10.1039/c8bm01246f

Huard J, Bouchard JP, Roy R, Malouin F, Dansereau G, Labrecque C, Albert N, Richards CL, Lemieux B, Tremblay JP (1992) Human myoblast transplantation: preliminary results of 4 cases. Muscle Nerve 15(5):550-560. https://doi.org/10.1002/mus.880150504

Hughes CS, Postovit LM, Lajoie GA (2010) Matrigel: a complex protein mixture required for optimal growth of cell culture. Proteomics 10(9):1886-1890. https://doi.org/10.1002/ pmic. 200900758

Hwang Y, Suk S, Shih YR, Seo T, Du B, Xie Y, Li Z, Varghese S (2014) WNT3A promotes myogenesis of human embryonic stem cells and enhances in vivo engraftment. Sci Rep 4:5916. https://doi.org/10.1038/srep05916

Incitti T, Magli A, Darabi R, Yuan C, Lin K, Arpke RW, Azzag K, Yamamoto A, Stewart R, Thomson JA, Kyba M, Perlingeiro RCR (2019) Pluripotent stem cell-derived myogenic progenitors remodel their molecular signature upon in vivo engraftment. Proc Natl Acad Sci U S A 116(10):4346-4351. https://doi.org/10.1073/pnas. 1808303116

Ishii K, Sakurai H, Suzuki N, Mabuchi Y, Sekiya I, Sekiguchi K, Akazawa C (2018) Recapitulation of extracellular LAMININ environment maintains stemness of satellite cells in vitro. Stem Cell Reports 10(2):568-582. https://doi.org/10.1016/j.stemcr.2017.12.013

Ito N, Shimizu N, Tanaka H, Takeda S (2016) Enhancement of satellite cell transplantation efficiency by leukemia inhibitory factor. J Neuromuscul Dis 3(2):201-207. https://doi.org/ $10.3233 / \mathrm{JND}-160156$

Ito N, Kii I, Shimizu N, Tanaka H, Takeda S (2017) Direct reprogramming of fibroblasts into skeletal muscle progenitor cells by transcription factors enriched in undifferentiated subpopulation of satellite cells. Sci Rep 7(1):8097. https://doi.org/10.1038/s41598-017-08232-2

Itskovitz-Eldor J, Schuldiner M, Karsenti D, Eden A, Yanuka O, Amit M, Soreq H, Benvenisty N (2000) Differentiation of human embryonic stem cells into embryoid bodies compromising the three embryonic germ layers. Mol Med 6(2):88-95

Jankowski RJ, Tu LM, Carlson C, Robert M, Carlson K, Quinlan D, Eisenhardt A, Chen M, Snyder S, Pruchnic R, Chancellor M, Dmochowski R, Kaufman MR, Carr L (2018) A double-blind, randomized, placebo-controlled clinical trial evaluating the safety and efficacy of autologous muscle derived cells in female subjects with stress urinary incontinence. Int Urol Nephrol 50 (12):2153-2165. https://doi.org/10.1007/s11255-018-2005-8

Joe AW, Yi L, Natarajan A, Le Grand F, So L, Wang J, Rudnicki MA, Rossi FM (2010) Muscle injury activates resident fibro/adipogenic progenitors that facilitate myogenesis. Nat Cell Biol 12(2):153-163. https://doi.org/10.1038/ncb2015

Jones NC, Tyner KJ, Nibarger L, Stanley HM, Cornelison DD, Fedorov YV, Olwin BB (2005) The p38alpha/beta MAPK functions as a molecular switch to activate the quiescent satellite cell. J Cell Biol 169(1):105-116. https://doi.org/10.1083/jcb.200408066

Judson RN, Quarta M, Oudhoff MJ, Soliman H, Yi L, Chang CK, Loi G, Vander Werff R, Cait A, Hamer M, Blonigan J, Paine P, Doan LTN, Groppa E, He W, Su L, Zhang RH, Xu P, Eisner C, Low M, Barta I, Lewis CB, Zaph C, Karimi MM, Rando TA, Rossi FM (2018) Inhibition of methyltransferase Setd7 allows the in vitro expansion of myogenic stem cells with improved therapeutic potential. Cell Stem Cell 22(2):177-190 e177. https://doi.org/10.1016/j. stem.2017.12.010 
Juhas M, Bursac N (2013) Engineering skeletal muscle repair. Curr Opin Biotechnol 24(5):880 886. https://doi.org/10.1016/j.copbio.2013.04.013

Juhas M, Engelmayr GC Jr, Fontanella AN, Palmer GM, Bursac N (2014) Biomimetic engineered muscle with capacity for vascular integration and functional maturation in vivo. Proc Natl Acad Sci U S A 111(15):5508-5513. https://doi.org/10.1073/pnas.1402723111

Juhas M, Abutaleb N, Wang JT, Ye J, Shaikh Z, Sriworarat C, Qian Y, Bursac N (2018) Incorporation of macrophages into engineered skeletal muscle enables enhanced muscle regeneration. Nat Biomed Eng 2(12):942-954. https://doi.org/10.1038/s41551-018-0290-2

Kang HW, Lee SJ, Ko IK, Kengla C, Yoo JJ, Atala A (2016) A 3D bioprinting system to produce human-scale tissue constructs with structural integrity. Nat Biotechnol 34(3):312-319. https:// doi.org/10.1038/nbt.3413

Karpati G, Pouliot Y, Zubrzycka-Gaarn E, Carpenter S, Ray PN, Worton RG, Holland P (1989) Dystrophin is expressed in $\mathrm{mdx}$ skeletal muscle fibers after normal myoblast implantation. Am J Pathol 135(1):27-32

Karpati G, Ajdukovic D, Arnold D, Gledhill RB, Guttmann R, Holland P, Koch PA, Shoubridge E, Spence D, Vanasse M et al (1993) Myoblast transfer in Duchenne muscular dystrophy. Ann Neurol 34(1):8-17. https://doi.org/10.1002/ana.410340105

Kaufman T, Kaplan B, Perry L, Shandalov Y, Landau S, Srugo I, Ad-El D, Levenberg S (2019) Innervation of an engineered muscle graft for reconstruction of muscle defects. Am J Transplant 19(1):37-47. https://doi.org/10.1111/ajt.14957

Kaully T, Kaufman-Francis K, Lesman A, Levenberg S (2009) Vascularization-the conduit to viable engineered tissues. Tissue Eng Part B Rev 15(2):159-169. https://doi.org/10.1089/ten. teb.2008.0193

Kim J, Magli A, Chan SSK, Oliveira VKP, Wu J, Darabi R, Kyba M, Perlingeiro RCR (2017) Expansion and purification are critical for the therapeutic application of pluripotent stem cellderived myogenic progenitors. Stem Cell Reports 9(1):12-22. https://doi.org/10.1016/j. stemcr.2017.04.022

Kinoshita I, Vilquin JT, Guerette B, Asselin I, Roy R, Tremblay JP (1994) Very efficient myoblast allotransplantation in mice under FK506 immunosuppression. Muscle Nerve 17(12):14071415. https://doi.org/10.1002/mus. 880171210

Kinoshita I, Roy R, Dugre FJ, Gravel C, Roy B, Goulet M, Asselin I, Tremblay JP (1996) Myoblast transplantation in monkeys: control of immune response by FK506. J Neuropathol Exp Neurol 55(6):687-697. https://doi.org/10.1097/00005072-199606000-00002

Klingler W, Jurkat-Rott K, Lehmann-Horn F, Schleip R (2012) The role of fibrosis in Duchenne muscular dystrophy. Acta Myol 31(3):184-195

Klinkenberg M, Fischer S, Kremer T, Hernekamp F, Lehnhardt M, Daigeler A (2013) Comparison of anterolateral thigh, lateral arm, and parascapular free flaps with regard to donor-site morbidity and aesthetic and functional outcomes. Plast Reconstr Surg 131(2):293-302. https://doi.org/ 10.1097/PRS.0b013e31827786bc

Ko IK, Lee BK, Lee SJ, Andersson KE, Atala A, Yoo JJ (2013) The effect of in vitro formation of acetylcholine receptor (AChR) clusters in engineered muscle fibers on subsequent innervation of constructs in vivo. Biomaterials 34(13):3246-3255. https://doi.org/10.1016/j.biomaterials. 2013.01.029

Kodaka Y, Rabu G, Asakura A (2017) Skeletal muscle cell induction from pluripotent stem cells. Stem Cells Int 2017:1376151. https://doi.org/10.1155/2017/1376151

Koenig M, Hoffman EP, Bertelson CJ, Monaco AP, Feener C, Kunkel LM (1987) Complete cloning of the Duchenne muscular dystrophy (DMD) cDNA and preliminary genomic organization of the DMD gene in normal and affected individuals. Cell 50(3):509-517. https://doi.org/10.1016/ 0092-8674(87)90504-6

Koffler J, Kaufman-Francis K, Shandalov Y, Egozi D, Pavlov DA, Landesberg A, Levenberg S (2011) Improved vascular organization enhances functional integration of engineered skeletal muscle grafts. Proc Natl Acad Sci U S A 108(36):14789-14794. https://doi.org/10.1073/ pnas. 1017825108 
Kuang S, Kuroda K, Le Grand F, Rudnicki MA (2007) Asymmetric self-renewal and commitment of satellite stem cells in muscle. Cell 129(5):999-1010. https://doi.org/10.1016/j.cell.2007.03.044

Kuhl U, Ocalan M, Timpl R, von der Mark K (1986) Role of laminin and fibronectin in selecting myogenic versus fibrogenic cells from skeletal muscle cells in vitro. Dev Biol 117(2):628-635. https://doi.org/10.1016/0012-1606(86)90331-3

Kwee BJ, Mooney DJ (2017) Biomaterials for skeletal muscle tissue engineering. Curr Opin Biotechnol 47:16-22. https://doi.org/10.1016/j.copbio.2017.05.003

Lafreniere JF, Caron MC, Skuk D, Goulet M, Cheikh AR, Tremblay JP (2009) Growth factor coinjection improves the migration potential of monkey myogenic precursors without affecting cell transplantation success. Cell Transplant 18(7):719-730. https://doi.org/10.3727/09636 8909X470900

Lalit PA, Salick MR, Nelson DO, Squirrell JM, Shafer CM, Patel NG, Saeed I, Schmuck EG, Markandeya YS, Wong R, Lea MR, Eliceiri KW, Hacker TA, Crone WC, Kyba M, Garry DJ, Stewart R, Thomson JA, Downs KM, Lyons GE, Kamp TJ (2016) Lineage reprogramming of fibroblasts into proliferative induced cardiac progenitor cells by defined factors. Cell Stem Cell 18(3):354-367. https://doi.org/10.1016/j.stem.2015.12.001

Larkin LM, Van der Meulen JH, Dennis RG, Kennedy JB (2006) Functional evaluation of nerveskeletal muscle constructs engineered in vitro. In Vitro Cell Dev Biol Anim 42(3-4):75-82. https://doi.org/10.1290/0509064.1

Latil M, Rocheteau P, Chatre L, Sanulli S, Memet S, Ricchetti M, Tajbakhsh S, Chretien F (2012) Skeletal muscle stem cells adopt a dormant cell state post mortem and retain regenerative capacity. Nat Commun 3:903. https://doi.org/10.1038/ncomms 1890

Latroche C, Weiss-Gayet M, Muller L, Gitiaux C, Leblanc P, Liot S, Ben-Larbi S, Abou-Khalil R, Verger N, Bardot P, Magnan M, Chretien F, Mounier R, Germain S, Chazaud B (2017) Coupling between myogenesis and angiogenesis during skeletal muscle regeneration is stimulated by restorative macrophages. Stem Cell Reports 9(6):2018-2033. https://doi.org/10.1016/j. stemcr.2017.10.027

Law PK, Bertorini TE, Goodwin TG, Chen M, Fang QW, Li HJ, Kirby DS, Florendo JA, Herrod HG, Golden GS (1990) Dystrophin production induced by myoblast transfer therapy in Duchenne muscular dystrophy. Lancet 336(8707):114-115. https://doi.org/10.1016/0140-6736 (90)91628-n

Law PK, Goodwin TG, Fang QW, Chen M, Li HJ, Florendo JA, Kirby DS (1991) Myoblast transfer therapy for Duchenne muscular dystrophy. Acta Paediatr Jpn 33(2):206-215. https://doi.org/ 10.1111/j.1442-200x.1991.tb01545.x

Lee EJ, Kim M, Kim YD, Chung MJ, Elfadl A, Ulah HMA, Park D, Lee S, Park HS, Kim TH, Hwang D, Jeong KS (2018) Establishment of stably expandable induced myogenic stem cells by four transcription factors. Cell Death Dis 9(11):1092. https://doi.org/10.1038/s41419-018-1114-8

Lendlein A, Langer R (2002) Biodegradable, elastic shape-memory polymers for potential biomedical applications. Science 296(5573):1673-1676. https://doi.org/10.1126/science.1066102

Lepper C, Partridge TA, Fan CM (2011) An absolute requirement for Pax7-positive satellite cells in acute injury-induced skeletal muscle regeneration. Development 138(17):3639-3646. https:// doi.org/10.1242/dev.067595

Lesault PF, Theret M, Magnan M, Cuvellier S, Niu Y, Gherardi RK, Tremblay JP, Hittinger L, Chazaud B (2012) Macrophages improve survival, proliferation and migration of engrafted myogenic precursor cells into MDX skeletal muscle. PLoS One 7(10):e46698. https://doi.org/ 10.1371/journal.pone.0046698

Levenberg S, Rouwkema J, Macdonald M, Garfein ES, Kohane DS, Darland DC, Marini R, van Blitterswijk CA, Mulligan RC, D'Amore PA, Langer R (2005) Engineering vascularized skeletal muscle tissue. Nat Biotechnol 23(7):879-884. https://doi.org/10.1038/nbt1109

Li HL, Fujimoto N, Sasakawa N, Shirai S, Ohkame T, Sakuma T, Tanaka M, Amano N, Watanabe A, Sakurai H, Yamamoto T, Yamanaka S, Hotta A (2015) Precise correction of the dystrophin gene in duchenne muscular dystrophy patient induced pluripotent stem cells by TALEN and CRISPR-Cas9. Stem Cell Reports 4(1):143-154. https://doi.org/10.1016/j.stemcr.2014.10.013 
Lin CH, Lin YT, Yeh JT, Chen CT (2007) Free functioning muscle transfer for lower extremity posttraumatic composite structure and functional defect. Plast Reconstr Surg 119(7):2118-2126. https://doi.org/10.1097/01.prs.0000260595.85557.41

Liu L, Cheung TH, Charville GW, Hurgo BM, Leavitt T, Shih J, Brunet A, Rando TA (2013) Chromatin modifications as determinants of muscle stem cell quiescence and chronological aging. Cell Rep 4(1):189-204. https://doi.org/10.1016/j.celrep.2013.05.043

Long C, Amoasii L, Mireault AA, McAnally JR, Li H, Sanchez-Ortiz E, Bhattacharyya S, Shelton JM, Bassel-Duby R, Olson EN (2016) Postnatal genome editing partially restores dystrophin expression in a mouse model of muscular dystrophy. Science 351(6271):400-403. https://doi. org/10.1126/science.aad5725

Long C, Li H, Tiburcy M, Rodriguez-Caycedo C, Kyrychenko V, Zhou H, Zhang Y, Min YL, Shelton JM, Mammen PPA, Liaw NY, Zimmermann WH, Bassel-Duby R, Schneider JW, Olson EN (2018) Correction of diverse muscular dystrophy mutations in human engineered heart muscle by single-site genome editing. Sci Adv 4(1):eaap9004. https://doi.org/10.1126/sciadv. aap9004

Low S, Barnes JL, Zammit PS, Beauchamp JR (2018) Delta-like 4 activates Notch 3 to regulate self-renewal in skeletal muscle stem cells. Stem Cells 36 (3):458-466. https://doi.org/10.1002/ stem. 2757

Lujan E, Chanda S, Ahlenius H, Sudhof TC, Wernig M (2012) Direct conversion of mouse fibroblasts to self-renewing, tripotent neural precursor cells. Proc Natl Acad Sci U S A 109 (7):2527-2532. https://doi.org/10.1073/pnas.1121003109

Lukjanenko L, Jung MJ, Hegde N, Perruisseau-Carrier C, Migliavacca E, Rozo M, Karaz S, Jacot G, Schmidt M, Li L, Metairon S, Raymond F, Lee U, Sizzano F, Wilson DH, Dumont NA, Palini A, Fassler R, Steiner P, Descombes P, Rudnicki MA, Fan CM, von Maltzahn J, Feige JN, Bentzinger CF (2016) Loss of fibronectin from the aged stem cell niche affects the regenerative capacity of skeletal muscle in mice. Nat Med 22(8):897-905. https://doi.org/10.1038/nm.4126

Lukjanenko L, Karaz S, Stuelsatz P, Gurriaran-Rodriguez U, Michaud J, Dammone G, Sizzano F, Mashinchian O, Ancel S, Migliavacca E, Liot S, Jacot G, Metairon S, Raymond F, Descombes P, Palini A, Chazaud B, Rudnicki MA, Bentzinger CF, Feige JN (2019) Aging disrupts muscle stem cell function by impairing matricellular WISP1 secretion from fibro-adipogenic progenitors. Cell Stem Cell 24(3):433-446 e437. https://doi.org/10.1016/j.stem.2018.12.014

Machado L, Esteves de Lima J, Fabre O, Proux C, Legendre R, Szegedi A, Varet H, Ingerslev LR, Barres R, Relaix F, Mourikis P (2017) In situ fixation redefines quiescence and early activation of skeletal muscle stem cells. Cell Rep 21(7):1982-1993. https://doi.org/10.1016/j.celrep.2017.10.080

Machingal MA, Corona BT, Walters TJ, Kesireddy V, Koval CN, Dannahower A, Zhao W, Yoo JJ, Christ GJ (2011) A tissue-engineered muscle repair construct for functional restoration of an irrecoverable muscle injury in a murine model. Tissue Eng Part A 17(17-18):2291-2303. https://doi.org/10.1089/ten.TEA.2010.0682

Madden L, Juhas M, Kraus WE, Truskey GA, Bursac N (2015) Bioengineered human myobundles mimic clinical responses of skeletal muscle to drugs. Elife $4: \mathrm{e} 04885$. https://doi.org/10.7554/ eLife. 04885

Maffioletti SM, Noviello M, English K, Tedesco FS (2014) Stem cell transplantation for muscular dystrophy: the challenge of immune response. Biomed Res Int 2014:964010. https://doi.org/ 10.1155/2014/964010

Maffioletti SM, Gerli MF, Ragazzi M, Dastidar S, Benedetti S, Loperfido M, VandenDriessche T, Chuah MK, Tedesco FS (2015) Efficient derivation and inducible differentiation of expandable skeletal myogenic cells from human ES and patient-specific iPS cells. Nat Protoc 10(7):941958. https://doi.org/10.1038/nprot.2015.057

Maffioletti SM, Sarcar S, Henderson ABH, Mannhardt I, Pinton L, Moyle LA, Steele-Stallard H, Cappellari O, Wells KE, Ferrari G, Mitchell JS, Tyzack GE, Kotiadis VN, Khedr M, Ragazzi M, Wang W, Duchen MR, Patani R, Zammit PS, Wells DJ, Eschenhagen T, Tedesco FS (2018) Three-dimensional human iPSC-derived artificial skeletal muscles model muscular dystrophies 
and enable multilineage tissue engineering. Cell Rep 23(3):899-908. https://doi.org/10.1016/j. celrep.2018.03.091

Magli A, Perlingeiro RRC (2017) Myogenic progenitor specification from pluripotent stem cells. Semin Cell Dev Biol 72:87-98. https://doi.org/10.1016/j.semcdb.2017.10.031

Magli A, Incitti T, Kiley J, Swanson SA, Darabi R, Rinaldi F, Selvaraj S, Yamamoto A, Tolar J, Yuan C, Stewart R, Thomson JA, Perlingeiro RCR (2017) PAX7 targets, CD54, integrin alpha9beta1, and SDC2, allow isolation of human ESC/iPSC-derived myogenic progenitors. Cell Rep 19(13):2867-2877. https://doi.org/10.1016/j.celrep.2017.06.005

Maley MA, Davies MJ, Grounds MD (1995) Extracellular matrix, growth factors, genetics: their influence on cell proliferation and myotube formation in primary cultures of adult mouse skeletal muscle. Exp Cell Res 219(1):169-179. https://doi.org/10.1006/excr.1995.1217

Malik N, Rao MS (2013) A review of the methods for human iPSC derivation. Methods Mol Biol 997:23-33. https://doi.org/10.1007/978-1-62703-348-0_3

Mao AS, Mooney DJ (2015) Regenerative medicine: current therapies and future directions. Proc Natl Acad Sci U S A 112(47):14452-14459. https://doi.org/10.1073/pnas.1508520112

Marg A, Escobar H, Gloy S, Kufeld M, Zacher J, Spuler A, Birchmeier C, Izsvak Z, Spuler S (2014) Human satellite cells have regenerative capacity and are genetically manipulable. J Clin Invest 124(10):4257-4265. https://doi.org/10.1172/JCI63992

Martin GR (1981) Isolation of a pluripotent cell line from early mouse embryos cultured in medium conditioned by teratocarcinoma stem cells. Proc Natl Acad Sci U S A 78(12):7634-7638. https://doi.org/10.1073/pnas.78.12.7634

Martin NR, Passey SL, Player DJ, Mudera V, Baar K, Greensmith L, Lewis MP (2015) Neuromuscular junction formation in tissue-engineered skeletal muscle augments contractile function and improves cytoskeletal organization. Tissue Eng Part A 21(19-20):2595-2604. https://doi.org/ 10.1089/ten.TEA.2015.0146

Matre PR, Mu X, Wu J, Danila D, Hall MA, Kolonin MG, Darabi R, Huard J (2019) CRISPR/Cas9based dystrophin restoration reveals a novel role for dystrophin in bioenergetics and stress resistance of muscle progenitors. Stem Cells 37(12):1615-1628. https://doi.org/10.1002/ stem.3094

Matthias N, Hunt SD, Wu J, Lo J, Smith Callahan LA, Li Y, Huard J, Darabi R (2018) Volumetric muscle loss injury repair using in situ fibrin gel cast seeded with muscle-derived stem cells (MDSCs). Stem Cell Res 27:65-73. https://doi.org/10.1016/j.scr.2018.01.008

Mauro A (1961) Satellite cell of skeletal muscle fibers. J Biophys Biochem Cytol 9:493-495

Mendell JR, Kissel JT, Amato AA, King W, Signore L, Prior TW, Sahenk Z, Benson S, McAndrew PE, Rice R et al (1995) Myoblast transfer in the treatment of Duchenne's muscular dystrophy. N Engl J Med 333(13):832-838. https://doi.org/10.1056/NEJM199509283331303

Miller RG, Sharma KR, Pavlath GK, Gussoni E, Mynhier M, Lanctot AM, Greco CM, Steinman L, Blau HM (1997) Myoblast implantation in Duchenne muscular dystrophy: the San Francisco study. Muscle Nerve 20(4):469-478. https://doi.org/10.1002/(sici)1097-4598(199704) 20:4<469::aid-mus10>3.0.co;2-u

Min YL, Bassel-Duby R, Olson EN (2019) CRISPR correction of duchenne muscular dystrophy. Annu Rev Med 70:239-255. https://doi.org/10.1146/annurev-med-081117-010451

Mintz EL, Passipieri JA, Franklin IR, Toscano VM, Afferton EC, Sharma PR, Christ GJ (2019) Long-term evaluation of functional outcomes following rat volumetric muscle loss injury and repair. Tissue Eng Part A. https://doi.org/10.1089/ten.TEA.2019.0126

Mitterberger M, Pinggera GM, Marksteiner R, Margreiter E, Fussenegger M, Frauscher F, Ulmer H, Hering S, Bartsch G, Strasser H (2008) Adult stem cell therapy of female stress urinary incontinence. Eur Urol 53(1):169-175. https://doi.org/10.1016/j.eururo.2007.07.026

Mizuno Y, Chang H, Umeda K, Niwa A, Iwasa T, Awaya T, Fukada S, Yamamoto H, Yamanaka S, Nakahata T, Heike T (2010) Generation of skeletal muscle stem/progenitor cells from murine induced pluripotent stem cells. FASEB J 24(7):2245-2253. https://doi.org/10.1096/fj.09137174 
Montarras D, Morgan J, Collins C, Relaix F, Zaffran S, Cumano A, Partridge T, Buckingham M (2005) Direct isolation of satellite cells for skeletal muscle regeneration. Science 309 (5743):2064-2067. https://doi.org/10.1126/science.1114758

Morandi L, Bernasconi P, Gebbia M, Mora M, Crosti F, Mantegazza R, Cornelio F (1995) Lack of mRNA and dystrophin expression in DMD patients three months after myoblast transfer. Neuromuscul Disord 5(4):291-295

Morgan JE, Moore SE, Walsh FS, Partridge TA (1992) Formation of skeletal muscle in vivo from the mouse C2 cell line. J Cell Sci 102(Pt 4):779-787

Morimoto Y, Kato-Negishi M, Onoe H, Takeuchi S (2013) Three-dimensional neuron-muscle constructs with neuromuscular junctions. Biomaterials 34(37):9413-9419. https://doi.org/ 10.1016/j.biomaterials.2013.08.062

Motohashi N, Shimizu-Motohashi Y, Roberts TC, Aoki Y (2019) Potential therapies using myogenic stem cells combined with bio-engineering approaches for treatment of muscular dystrophies. Cells 8(9). https://doi.org/10.3390/cells8091066

Mourikis P, Tajbakhsh S (2014) Distinct contextual roles for Notch signalling in skeletal muscle stem cells. BMC Dev Biol 14:2. https://doi.org/10.1186/1471-213X-14-2

Mourikis P, Sambasivan R, Castel D, Rocheteau P, Bizzarro V, Tajbakhsh S (2012) A critical requirement for notch signaling in maintenance of the quiescent skeletal muscle stem cell state. Stem Cells 30(2):243-252. https://doi.org/10.1002/stem.775

Mueller AL, Bloch RJ (2019) Skeletal muscle cell transplantation: models and methods. J Muscle Res Cell Motil. https://doi.org/10.1007/s10974-019-09550-w

Munoz-Canoves P, Scheele C, Pedersen BK, Serrano AL (2013) Interleukin-6 myokine signaling in skeletal muscle: a double-edged sword? FEBS J 280(17):4131-4148. https://doi.org/10.1111/ febs. 12338

Murphy MM, Lawson JA, Mathew SJ, Hutcheson DA, Kardon G (2011) Satellite cells, connective tissue fibroblasts and their interactions are crucial for muscle regeneration. Development 138 (17):3625-3637. https://doi.org/10.1242/dev.064162

Nakayama KH, Quarta M, Paine P, Alcazar C, Karakikes I, Garcia V, Abilez OJ, Calvo NS, Simmons CS, Rando TA, Huang NF (2019) Treatment of volumetric muscle loss in mice using nanofibrillar scaffolds enhances vascular organization and integration. Commun Biol 2:170. https://doi.org/10.1038/s42003-019-0416-4

Nance ME, Shi R, Hakim CH, Wasala NB, Yue Y, Pan X, Zhang T, Robinson CA, Duan SX, Yao G, Yang NN, Chen SJ, Wagner KR, Gersbach CA, Duan D (2019) AAV9 edits muscle stem cells in normal and dystrophic adult mice. Mol Ther 27(9):1568-1585. https://doi.org/10.1016/j. ymthe.2019.06.012

National Institutes of Health Consensus Development (1983) Clinical applications of biomaterials. Natl Inst Health Consens Dev Conf Summ 4(5).:10 p

Neal D, Sakar MS, Ong LL, Harry Asada H (2014) Formation of elongated fascicle-inspired 3D tissues consisting of high-density, aligned cells using sacrificial outer molding. Lab Chip 14 (11):1907-1916. https://doi.org/10.1039/c4lc00023d

Negroni E, Bigot A, Butler-Browne GS, Trollet C, Mouly V (2016) Cellular therapies for muscular dystrophies: frustrations and clinical successes. Hum Gene Ther 27(2):117-126. https://doi.org/ 10.1089/hum.2015.139

Nelson CE, Hakim CH, Ousterout DG, Thakore PI, Moreb EA, Castellanos Rivera RM, Madhavan S, Pan X, Ran FA, Yan WX, Asokan A, Zhang F, Duan D, Gersbach CA (2016) In vivo genome editing improves muscle function in a mouse model of Duchenne muscular dystrophy. Science 351(6271):403-407. https://doi.org/10.1126/science.aad5143

Nicola NA, Babon JJ (2015) Leukemia inhibitory factor (LIF). Cytokine Growth Factor Rev 26 (5):533-544. https://doi.org/10.1016/j.cytogfr.2015.07.001

Novak ML, Weinheimer-Haus EM, Koh TJ (2014) Macrophage activation and skeletal muscle healing following traumatic injury. J Pathol 232(3):344-355. https://doi.org/10.1002/path.4301

Nowak KJ, Davies KE (2004) Duchenne muscular dystrophy and dystrophin: pathogenesis and opportunities for treatment. EMBO Rep 5(9):872-876. https://doi.org/10.1038/sj.embor.7400221 
Ocalan M, Goodman SL, Kuhl U, Hauschka SD, von der Mark K (1988) Laminin alters cell shape and stimulates motility and proliferation of murine skeletal myoblasts. Dev Biol 125(1):158167. https://doi.org/10.1016/0012-1606(88)90068-1

Ortiz-Vitali JL, Darabi R (2019) iPSCs as a platform for disease modeling, drug screening, and personalized therapy in muscular dystrophies. Cells 8(1). https://doi.org/10.3390/cells 8010020

Osaki T, Sivathanu V, Kamm RD (2018a) Crosstalk between developing vasculature and optogenetically engineered skeletal muscle improves muscle contraction and angiogenesis. Biomaterials 156:65-76. https://doi.org/10.1016/j.biomaterials.2017.11.041

Osaki T, Uzel SGM, Kamm RD (2018b) Microphysiological 3D model of amyotrophic lateral sclerosis (ALS) from human iPS-derived muscle cells and optogenetic motor neurons. Sci Adv 4 (10):eaat5847. https://doi.org/10.1126/sciadv.aat5847

Oustanina S, Hause G, Braun T (2004) Pax7 directs postnatal renewal and propagation of myogenic satellite cells but not their specification. EMBO J 23(16):3430-3439. https://doi.org/10.1038/sj. emboj.7600346

Ousterout DG, Kabadi AM, Thakore PI, Majoros WH, Reddy TE, Gersbach CA (2015) Multiplex CRISPR/Cas9-based genome editing for correction of dystrophin mutations that cause Duchenne muscular dystrophy. Nat Commun 6:6244. https://doi.org/10.1038/ncomms 7244

Ozasa S, Kimura S, Ito K, Ueno H, Ikezawa M, Matsukura M, Yoshioka K, Araki K, Yamamura KI, Abe K, Niwa H, Miike T (2007) Efficient conversion of ES cells into myogenic lineage using the gene-inducible system. Biochem Biophys Res Commun 357(4):957-963. https://doi.org/ 10.1016/j.bbrc.2007.04.032

Page RL, Malcuit C, Vilner L, Vojtic I, Shaw S, Hedblom E, Hu J, Pins GD, Rolle MW, Dominko T (2011) Restoration of skeletal muscle defects with adult human cells delivered on fibrin microthreads. Tissue Eng Part A 17(21-22):2629-2640. https://doi.org/10.1089/ten. TEA.2011.0024

Pantelic MN, Larkin LM (2018) Stem cells for skeletal muscle tissue engineering. Tissue Eng Part B Rev 24(5):373-391. https://doi.org/10.1089/ten.TEB.2017.0451

Park IH, Arora N, Huo H, Maherali N, Ahfeldt T, Shimamura A, Lensch MW, Cowan C, Hochedlinger K, Daley GQ (2008) Disease-specific induced pluripotent stem cells. Cell 134 (5):877-886. https://doi.org/10.1016/j.cell.2008.07.041

Parker MH, Loretz C, Tyler AE, Duddy WJ, Hall JK, Olwin BB, Bernstein ID, Storb R, Tapscott SJ (2012) Activation of Notch signaling during ex vivo expansion maintains donor muscle cell engraftment. Stem Cells 30(10):2212-2220. https://doi.org/10.1002/stem.1181

Partridge TA, Grounds M, Sloper JC (1978) Evidence of fusion between host and donor myoblasts in skeletal muscle grafts. Nature 273(5660):306-308. https://doi.org/10.1038/273306a0

Partridge TA, Morgan JE, Coulton GR, Hoffman EP, Kunkel LM (1989) Conversion of mdx myofibres from dystrophin-negative to -positive by injection of normal myoblasts. Nature 337 (6203):176-179. https://doi.org/10.1038/337176a0

Pasut A, Chang NC, Gurriaran-Rodriguez U, Faulkes S, Yin H, Lacaria M, Ming H, Rudnicki MA (2016) Notch signaling rescues loss of satellite cells lacking Pax7 and promotes brown adipogenic differentiation. Cell Rep 16(2):333-343. https://doi.org/10.1016/j.celrep.2016.06.001

Pavlath GK, Rando TA, Blau HM (1994) Transient immunosuppressive treatment leads to longterm retention of allogeneic myoblasts in hybrid myofibers. J Cell Biol 127(6 Pt 2):1923-1932. https://doi.org/10.1083/jcb.127.6.1923

Pawlowski M, Ortmann D, Bertero A, Tavares JM, Pedersen RA, Vallier L, Kotter MRN (2017) Inducible and deterministic forward programming of human pluripotent stem cells into neurons, skeletal myocytes, and oligodendrocytes. Stem Cell Reports 8(4):803-812. https://doi.org/ 10.1016/j.stemcr.2017.02.016

Penton CM, Badarinarayana V, Prisco J, Powers E, Pincus M, Allen RE, August PR (2016) Laminin 521 maintains differentiation potential of mouse and human satellite cell-derived myoblasts during long-term culture expansion. Skelet Muscle 6(1):44. https://doi.org/10.1186/s13395016-0116-4 
Perie S, Mamchaoui K, Mouly V, Blot S, Bouazza B, Thornell LE, St Guily JL, Butler-Browne G (2006) Premature proliferative arrest of cricopharyngeal myoblasts in oculo-pharyngeal muscular dystrophy: therapeutic perspectives of autologous myoblast transplantation. Neuromuscul Disord 16(11):770-781. https://doi.org/10.1016/j.nmd.2006.07.022

Perie S, Trollet C, Mouly V, Vanneaux V, Mamchaoui K, Bouazza B, Marolleau JP, Laforet P, Chapon F, Eymard B, Butler-Browne G, Larghero J, St Guily JL (2014) Autologous myoblast transplantation for oculopharyngeal muscular dystrophy: a phase I/IIa clinical study. Mol Ther 22(1):219-225. https://doi.org/10.1038/mt.2013.155

Pietrosemoli N, Mella S, Yennek S, Baghdadi MB, Sakai H, Sambasivan R, Pala F, Di Girolamo D, Tajbakhsh S (2017) Comparison of multiple transcriptomes exposes unified and divergent features of quiescent and activated skeletal muscle stem cells. Skelet Muscle 7(1):28. https:// doi.org/10.1186/s13395-017-0144-8

Powell C, Shansky J, Del Tatto M, Forman DE, Hennessey J, Sullivan K, Zielinski BA, Vandenburgh HH (1999) Tissue-engineered human bioartificial muscles expressing a foreign recombinant protein for gene therapy. Hum Gene Ther 10(4):565-577. https://doi.org/10.1089/ 10430349950018643

Qazi TH, Mooney DJ, Pumberger M, Geissler S, Duda GN (2015) Biomaterials based strategies for skeletal muscle tissue engineering: existing technologies and future trends. Biomaterials 53:502-521. https://doi.org/10.1016/j.biomaterials.2015.02.110

Qu Z, Balkir L, van Deutekom JC, Robbins PD, Pruchnic R, Huard J (1998) Development of approaches to improve cell survival in myoblast transfer therapy. J Cell Biol 142(5):1257-1267. https://doi.org/10.1083/jcb.142.5.1257

Quarta M, Brett JO, DiMarco R, De Morree A, Boutet SC, Chacon R, Gibbons MC, Garcia VA, Su J, Shrager JB, Heilshorn S, Rando TA (2016) An artificial niche preserves the quiescence of muscle stem cells and enhances their therapeutic efficacy. Nat Biotechnol 34(7):752-759. https://doi.org/10.1038/nbt.3576

Quarta M, Cromie M, Chacon R, Blonigan J, Garcia V, Akimenko I, Hamer M, Paine P, Stok M, Shrager JB, Rando TA (2017) Bioengineered constructs combined with exercise enhance stem cell-mediated treatment of volumetric muscle loss. Nat Commun 8:15613. https://doi.org/ $10.1038 /$ ncomms 15613

Quarta M, Cromie Lear MJ, Blonigan J, Paine P, Chacon R, Rando TA (2018) Biomechanics show stem cell necessity for effective treatment of volumetric muscle loss using bioengineered constructs. NPJ Regen Med 3:18. https://doi.org/10.1038/s41536-018-0057-0

Quenneville SP, Chapdelaine P, Skuk D, Paradis M, Goulet M, Rousseau J, Xiao X, Garcia L, Tremblay JP (2007) Autologous transplantation of muscle precursor cells modified with a lentivirus for muscular dystrophy: human cells and primate models. Mol Ther 15(2):431-438. https://doi.org/10.1038/sj.mt.6300047

Rando TA, Blau HM (1994) Primary mouse myoblast purification, characterization, and transplantation for cell-mediated gene therapy. J Cell Biol 125(6):1275-1287. https://doi.org/10.1083/ jcb.125.6.1275

Rao N, Agmon G, Tierney MT, Ungerleider JL, Braden RL, Sacco A, Christman KL (2017) Engineering an injectable muscle-specific microenvironment for improved cell delivery using a nanofibrous extracellular matrix hydrogel. ACS Nano 11(4):3851-3859. https://doi.org/ 10.1021/acsnano.7b00093

Rao L, Qian Y, Khodabukus A, Ribar T, Bursac N (2018) Engineering human pluripotent stem cells into a functional skeletal muscle tissue. Nat Commun 9(1):126. https://doi.org/10.1038/s41467017-02636-4

Rayagiri SS, Ranaldi D, Raven A, Mohamad Azhar NIF, Lefebvre O, Zammit PS, Borycki AG (2018) Basal lamina remodeling at the skeletal muscle stem cell niche mediates stem cell selfrenewal. Nat Commun 9(1):1075. https://doi.org/10.1038/s41467-018-03425-3

Ring KL, Tong LM, Balestra ME, Javier R, Andrews-Zwilling Y, Li G, Walker D, Zhang WR, Kreitzer AC, Huang Y (2012) Direct reprogramming of mouse and human fibroblasts into 
multipotent neural stem cells with a single factor. Cell Stem Cell 11(1):100-109. https://doi.org/ 10.1016/j.stem.2012.05.018

Rocheteau P, Gayraud-Morel B, Siegl-Cachedenier I, Blasco MA, Tajbakhsh S (2012) A subpopulation of adult skeletal muscle stem cells retains all template DNA strands after cell division. Cell 148(1-2):112-125. https://doi.org/10.1016/j.cell.2011.11.049

Romaniszyn M, Rozwadowska N, Malcher A, Kolanowski T, Walega P, Kurpisz M (2015) Implantation of autologous muscle-derived stem cells in treatment of fecal incontinence: results of an experimental pilot study. Tech Coloproctol 19(11):685-696. https://doi.org/10.1007/ s10151-015-1351-0

Rossi CA, Flaibani M, Blaauw B, Pozzobon M, Figallo E, Reggiani C, Vitiello L, Elvassore N, De Coppi P (2011) In vivo tissue engineering of functional skeletal muscle by freshly isolated satellite cells embedded in a photopolymerizable hydrogel. FASEB J 25(7):2296-2304. https:// doi.org/10.1096/fj.10-174755

Rubenstein AB, Smith GR, Raue U, Begue G, Minchev K, Ruf-Zamojski F, Nair VD, Wang X, Zhou L, Zaslavsky E, Trappe TA, Trappe S, Sealfon SC (2020) Single-cell transcriptional profiles in human skeletal muscle. Sci Rep 10(1):229. https://doi.org/10.1038/s41598-01957110-6

Ruoslahti E, Pierschbacher MD (1987) New perspectives in cell adhesion: RGD and integrins. Science 238(4826):491-497. https://doi.org/10.1126/science.2821619

Sacco A, Doyonnas R, Kraft P, Vitorovic S, Blau HM (2008) Self-renewal and expansion of single transplanted muscle stem cells. Nature 456(7221):502-506. https://doi.org/10.1038/nature07384

Sakai H, Fukuda S, Nakamura M, Uezumi A, Noguchi YT, Sato T, Morita M, Yamada H, Tsuchida K, Tajbakhsh S, Fukada SI (2017) Notch ligands regulate the muscle stem-like state ex vivo but are not sufficient for retaining regenerative capacity. PLoS One 12(5):e0177516. https://doi.org/ 10.1371/journal.pone. 0177516

Sambasivan R, Gayraud-Morel B, Dumas G, Cimper C, Paisant S, Kelly RG, Tajbakhsh S (2009) Distinct regulatory cascades govern extraocular and pharyngeal arch muscle progenitor cell fates. Dev Cell 16(6):810-821. https://doi.org/10.1016/j.devcel.2009.05.008

Sambasivan R, Yao R, Kissenpfennig A, Van Wittenberghe L, Paldi A, Gayraud-Morel B, Guenou H, Malissen B, Tajbakhsh S, Galy A (2011) Pax7-expressing satellite cells are indispensable for adult skeletal muscle regeneration. Development 138(17):3647-3656. https://doi.org/10.1242/ dev.067587

Sampaolesi M, Torrente Y, Innocenzi A, Tonlorenzi R, D'Antona G, Pellegrino MA, Barresi R, Bresolin N, De Angelis MG, Campbell KP, Bottinelli R, Cossu G (2003) Cell therapy of alphasarcoglycan null dystrophic mice through intra-arterial delivery of mesoangioblasts. Science 301(5632):487-492. https://doi.org/10.1126/science.1082254

Sampath SC, Sampath SC, Ho ATV, Corbel SY, Millstone JD, Lamb J, Walker J, Kinzel B, Schmedt C, Blau HM (2018) Induction of muscle stem cell quiescence by the secreted niche factor Oncostatin M. Nat Commun 9(1):1531. https://doi.org/10.1038/s41467-018-03876-8

Sato T, Higashioka K, Sakurai H, Yamamoto T, Goshima N, Ueno M, Sotozono C (2019) Core transcription factors promote induction of PAX3-positive skeletal muscle stem cells. Stem Cell Reports 13(2):352-365. https://doi.org/10.1016/j.stemcr.2019.06.006

Schultz E, Gibson MC, Champion T (1978) Satellite cells are mitotically quiescent in mature mouse muscle: an EM and radioautographic study. J Exp Zool 206(3):451-456. https://doi.org/ 10.1002/jez.1402060314

Schwartz SD, Hubschman JP, Heilwell G, Franco-Cardenas V, Pan CK, Ostrick RM, Mickunas E, Gay R, Klimanskaya I, Lanza R (2012) Embryonic stem cell trials for macular degeneration: a preliminary report. Lancet 379(9817):713-720. https://doi.org/10.1016/S0140-6736(12)60028-2

Seale P, Sabourin LA, Girgis-Gabardo A, Mansouri A, Gruss P, Rudnicki MA (2000) Pax7 is required for the specification of myogenic satellite cells. Cell 102(6):777-786

Sebe P, Doucet C, Cornu JN, Ciofu C, Costa P, de Medina SG, Pinset C, Haab F (2011) Intrasphincteric injections of autologous muscular cells in women with refractory stress urinary 
incontinence: a prospective study. Int Urogynecol J 22(2):183-189. https://doi.org/10.1007/ s00192-010-1255-5

Selvaraj S, Kyba M, Perlingeiro RCR (2019) Pluripotent stem cell-based therapeutics for muscular dystrophies. Trends Mol Med 25(9):803-816. https://doi.org/10.1016/j.molmed.2019.07.004

Shea KL, Xiang W, LaPorta VS, Licht JD, Keller C, Basson MA, Brack AS (2010) Sprouty1 regulates reversible quiescence of a self-renewing adult muscle stem cell pool during regeneration. Cell Stem Cell 6(2):117-129. https://doi.org/10.1016/j.stem.2009.12.015

Shelton M, Metz J, Liu J, Carpenedo RL, Demers SP, Stanford WL, Skerjanc IS (2014) Derivation and expansion of PAX7-positive muscle progenitors from human and mouse embryonic stem cells. Stem Cell Reports 3(3):516-529. https://doi.org/10.1016/j.stemcr.2014.07.001

Sherwood RI, Christensen JL, Conboy IM, Conboy MJ, Rando TA, Weissman IL, Wagers AJ (2004) Isolation of adult mouse myogenic progenitors: functional heterogeneity of cells within and engrafting skeletal muscle. Cell 119(4):543-554. https://doi.org/10.1016/j.cell.2004.10.021

Sicari BM, Rubin JP, Dearth CL, Wolf MT, Ambrosio F, Boninger M, Turner NJ, Weber DJ, Simpson TW, Wyse A, Brown EH, Dziki JL, Fisher LE, Brown S, Badylak SF (2014) An acellular biologic scaffold promotes skeletal muscle formation in mice and humans with volumetric muscle loss. Sci Transl Med 6(234):234ra258. https://doi.org/10.1126/ scitranslmed.3008085

Simillis C, Lal N, Pellino G, Baird D, Nikolaou S, Kontovounisios C, Smith JJ, Tekkis PP (2019) A systematic review and network meta-analysis comparing treatments for faecal incontinence. Int J Surg 66:37-47. https://doi.org/10.1016/j.ijsu.2019.04.007

Simone C, Forcales SV, Hill DA, Imbalzano AN, Latella L, Puri PL (2004) p38 pathway targets SWI-SNF chromatin-remodeling complex to muscle-specific loci. Nat Genet 36(7):738-743. https://doi.org/10.1038/ng1378

Skuk D (2004) Myoblast transplantation for inherited myopathies: a clinical approach. Expert Opin Biol Ther 4(12):1871-1885. https://doi.org/10.1517/14712598.4.12.1871

Skuk D, Tremblay JP (2014) Clarifying misconceptions about myoblast transplantation in myology. Mol Ther 22(5):897-898. https://doi.org/10.1038/mt.2014.57

Skuk D, Tremblay JP (2016) Confirmation of donor-derived dystrophin in a duchenne muscular dystrophy patient allotransplanted with normal myoblasts. Muscle Nerve 54(5):979-981. https://doi.org/10.1002/mus.25129

Skuk D, Tremblay JP (2017a) Cell therapy in myology: dynamics of muscle precursor cell death after intramuscular administration in non-human primates. Mol Ther Methods Clin Dev 5:232 240. https://doi.org/10.1016/j.omtm.2017.05.002

Skuk D, Tremblay JP (2017b) The process of engraftment of myogenic cells in skeletal muscles of primates: understanding clinical observations and setting directions in cell transplantation research. Cell Transplant 26(11):1763-1779. https://doi.org/10.1177/0963689717724798

Skuk D, Roy B, Goulet M, Tremblay JP (1999) Successful myoblast transplantation in primates depends on appropriate cell delivery and induction of regeneration in the host muscle. Exp Neurol 155(1):22-30. https://doi.org/10.1006/exnr.1998.6973

Skuk D, Goulet M, Roy B, Tremblay JP (2000) Myoblast transplantation in whole muscle of nonhuman primates. J Neuropathol Exp Neurol 59(3):197-206. https://doi.org/10.1093/jnen/ 59.3.197

Skuk D, Goulet M, Roy B, Tremblay JP (2002) Efficacy of myoblast transplantation in nonhuman primates following simple intramuscular cell injections: toward defining strategies applicable to humans. Exp Neurol 175(1):112-126. https://doi.org/10.1006/exnr.2002.7899

Skuk D, Roy B, Goulet M, Chapdelaine P, Bouchard JP, Roy R, Dugre FJ, Lachance JG, Deschenes L, Helene S, Sylvain M, Tremblay JP (2004) Dystrophin expression in myofibers of Duchenne muscular dystrophy patients following intramuscular injections of normal myogenic cells. Mol Ther 9(3):475-482. https://doi.org/10.1016/j.ymthe.2003.11.023

Skuk D, Goulet M, Roy B, Chapdelaine P, Bouchard JP, Roy R, Dugre FJ, Sylvain M, Lachance JG, Deschenes L, Senay H, Tremblay JP (2006a) Dystrophin expression in muscles of duchenne 
muscular dystrophy patients after high-density injections of normal myogenic cells. J Neuropathol Exp Neurol 65(4):371-386. https://doi.org/10.1097/01.jnen.0000218443.45782.81

Skuk D, Goulet M, Tremblay JP (2006b) Use of repeating dispensers to increase the efficiency of the intramuscular myogenic cell injection procedure. Cell Transplant 15(7):659-663. https://doi. org $/ 10.3727 / 000000006783981648$

Skuk D, Goulet M, Roy B, Piette V, Cote CH, Chapdelaine P, Hogrel JY, Paradis M, Bouchard JP, Sylvain M, Lachance JG, Tremblay JP (2007) First test of a "high-density injection" protocol for myogenic cell transplantation throughout large volumes of muscles in a Duchenne muscular dystrophy patient: eighteen months follow-up. Neuromuscul Disord 17(1):38-46. https://doi. org/10.1016/j.nmd.2006.10.003

Skuk D, Paradis M, Goulet M, Chapdelaine P, Rothstein DM, Tremblay JP (2010) Intramuscular transplantation of human postnatal myoblasts generates functional donor-derived satellite cells. Mol Ther 18(9):1689-1697. https://doi.org/10.1038/mt.2010.128

Skuk D, Goulet M, Tremblay JP (2011) Transplanted myoblasts can migrate several millimeters to fuse with damaged myofibers in nonhuman primate skeletal muscle. J Neuropathol Exp Neurol 70(9):770-778. https://doi.org/10.1097/NEN.0b013e31822a6baa

Skuk D, Goulet M, Tremblay JP (2013) Electroporation as a method to induce myofiber regeneration and increase the engraftment of myogenic cells in skeletal muscles of primates. $\mathrm{J}$ Neuropathol Exp Neurol 72(8):723-734. https://doi.org/10.1097/NEN.0b013e31829bac22

Skuk D, Goulet M, Tremblay JP (2014) Intramuscular transplantation of myogenic cells in primates: importance of needle size, cell number, and injection volume. Cell Transplant 23 (1):13-25. https://doi.org/10.3727/096368912X661337

Slater CR (2017) The structure of human neuromuscular junctions: some unanswered molecular questions. Int J Mol Sci 18(10). https://doi.org/10.3390/ijms18102183

Sleep E, Cosgrove BD, McClendon MT, Preslar AT, Chen CH, Sangji MH, Perez CMR, Haynes RD, Meade TJ, Blau HM, Stupp SI (2017) Injectable biomimetic liquid crystalline scaffolds enhance muscle stem cell transplantation. Proc Natl Acad Sci U S A 114(38):E7919-E7928. https://doi.org/10.1073/pnas.1708142114

Snow MH (1978) An autoradiographic study of satellite cell differentiation into regenerating myotubes following transplantation of muscles in young rats. Cell Tissue Res 186(3):535540. https://doi.org/10.1007/bf00224941

Stangel-Wojcikiewicz K, Jarocha D, Piwowar M, Jach R, Uhl T, Basta A, Majka M (2014) Autologous muscle-derived cells for the treatment of female stress urinary incontinence: a 2year follow-up of a Polish investigation. Neurourol Urodyn 33(3):324-330. https://doi.org/ 10.1002/nau.22404

Sun L, Ma K, Wang H, Xiao F, Gao Y, Zhang W, Wang K, Gao X, Ip N, Wu Z (2007) JAK1-STAT1STAT3, a key pathway promoting proliferation and preventing premature differentiation of myoblasts. J Cell Biol 179(1):129-138. https://doi.org/10.1083/jcb.200703184

Stefan Rose-John (2018) Interleukin-6 Family Cytokines. Cold Spring Harbor Perspectives in Biology 10(2):a028415

Tabebordbar M, Zhu K, Cheng JKW, Chew WL, Widrick JJ, Yan WX, Maesner C, Wu EY, Xiao R, Ran FA, Cong L, Zhang F, Vandenberghe LH, Church GM, Wagers AJ (2016) In vivo gene editing in dystrophic mouse muscle and muscle stem cells. Science 351(6271):407-411. https:// doi.org/10.1126/science.aad5177

Takahashi K, Yamanaka S (2006) Induction of pluripotent stem cells from mouse embryonic and adult fibroblast cultures by defined factors. Cell 126(4):663-676. https://doi.org/10.1016/j. cell.2006.07.024

Takahashi K, Tanabe K, Ohnuki M, Narita M, Ichisaka T, Tomoda K, Yamanaka S (2007) Induction of pluripotent stem cells from adult human fibroblasts by defined factors. Cell 131(5):861-872. https://doi.org/10.1016/j.cell.2007.11.019

Takahashi H, Shimizu T, Nakayama M, Yamato M, Okano T (2013) The use of anisotropic cell sheets to control orientation during the self-organization of 3D muscle tissue. Biomaterials 34 (30):7372-7380. https://doi.org/10.1016/j.biomaterials.2013.06.033 
Tanaka A, Woltjen K, Miyake K, Hotta A, Ikeya M, Yamamoto T, Nishino T, Shoji E, SeharaFujisawa A, Manabe Y, Fujii N, Hanaoka K, Era T, Yamashita S, Isobe K, Kimura E, Sakurai H (2013) Efficient and reproducible myogenic differentiation from human iPS cells: prospects for modeling Miyoshi myopathy in vitro. PLoS One 8(4):e61540. https://doi.org/10.1371/journal. pone. 0061540

Tapscott SJ, Davis RL, Thayer MJ, Cheng PF, Weintraub H, Lassar AB (1988) MyoD1: a nuclear phosphoprotein requiring a Myc homology region to convert fibroblasts to myoblasts. Science 242(4877):405-411. https://doi.org/10.1126/science.3175662

Thomson JA, Itskovitz-Eldor J, Shapiro SS, Waknitz MA, Swiergiel JJ, Marshall VS, Jones JM (1998) Embryonic stem cell lines derived from human blastocysts. Science 282(5391):11451147. https://doi.org/10.1126/science.282.5391.1145

Tierney MT, Aydogdu T, Sala D, Malecova B, Gatto S, Puri PL, Latella L, Sacco A (2014) STAT3 signaling controls satellite cell expansion and skeletal muscle repair. Nat Med 20(10):11821186. https://doi.org/10.1038/nm.3656

Torrente Y, Belicchi M, Sampaolesi M, Pisati F, Meregalli M, D’Antona G, Tonlorenzi R, Porretti L, Gavina M, Mamchaoui K, Pellegrino MA, Furling D, Mouly V, Butler-Browne GS, Bottinelli R, Cossu G, Bresolin N (2004) Human circulating AC133(+) stem cells restore dystrophin expression and ameliorate function in dystrophic skeletal muscle. J Clin Invest 114(2):182195. https://doi.org/10.1172/JCI20325

Torrente Y, Belicchi M, Marchesi C, D’Antona G, Cogiamanian F, Pisati F, Gavina M, Giordano R, Tonlorenzi R, Fagiolari G, Lamperti C, Porretti L, Lopa R, Sampaolesi M, Vicentini L, Grimoldi N, Tiberio F, Songa V, Baratta P, Prelle A, Forzenigo L, Guglieri M, Pansarasa O, Rinaldi C, Mouly V, Butler-Browne GS, Comi GP, Biondetti P, Moggio M, Gaini SM, Stocchetti N, Priori A, D’Angelo MG, Turconi A, Bottinelli R, Cossu G, Rebulla P, Bresolin N (2007) Autologous transplantation of muscle-derived $\mathrm{CD} 133+$ stem cells in Duchenne muscle patients. Cell Transplant 16(6):563-577

Trebol J, Carabias-Orgaz A, Garcia-Arranz M, Garcia-Olmo D (2018) Stem cell therapy for faecal incontinence: current state and future perspectives. World J Stem Cells 10(7):82-105. https:// doi.org/10.4252/wjsc.v10.i7.82

Tremblay JP, Bouchard JP, Malouin F, Theau D, Cottrell F, Collin H, Rouche A, Gilgenkrantz S, Abbadi N, Tremblay M et al (1993a) Myoblast transplantation between monozygotic twin girl carriers of Duchenne muscular dystrophy. Neuromuscul Disord 3(5-6):583-592

Tremblay JP, Malouin F, Roy R, Huard J, Bouchard JP, Satoh A, Richards CL (1993b) Results of a triple blind clinical study of myoblast transplantations without immunosuppressive treatment in young boys with Duchenne muscular dystrophy. Cell Transplant 2(2):99-112. https://doi.org/ 10.1177/096368979300200203

Tremblay JP, Skuk D, Palmieri B, Rothstein DM (2009) A case for immunosuppression for myoblast transplantation in duchenne muscular dystrophy. Mol Ther 17(7):1122-1124. https://doi.org/10.1038/mt.2009.125

Uezumi A, Nakatani M, Ikemoto-Uezumi M, Yamamoto N, Morita M, Yamaguchi A, Yamada H, Kasai T, Masuda S, Narita A, Miyagoe-Suzuki Y, Takeda S, Fukada S, Nishino I, Tsuchida K (2016) Cell-surface protein profiling identifies distinctive markers of progenitor cells in human skeletal muscle. Stem Cell Reports 7(2):263-278. https://doi.org/10.1016/j.stemcr.2016.07.004

Urciuolo A, Quarta M, Morbidoni V, Gattazzo F, Molon S, Grumati P, Montemurro F, Tedesco FS, Blaauw B, Cossu G, Vozzi G, Rando TA, Bonaldo P (2013) Collagen VI regulates satellite cell self-renewal and muscle regeneration. Nat Commun 4:1964. https://doi.org/10.1038/ ncomms 2964

van der Wal E, Herrero-Hernandez P, Wan R, Broeders M, In 't Groen SLM, van Gestel TJM, van IWFJ, Cheung TH, van der Ploeg AT, Schaaf GJ, Pijnappel W (2018) Large-scale expansion of human iPSC-derived skeletal muscle cells for disease modeling and cell-based therapeutic strategies. Stem Cell Reports 10 (6):1975-1990. https://doi.org/10.1016/j.stemcr.2018.04.002 
van Velthoven CTJ, de Morree A, Egner IM, Brett JO, Rando TA (2017) Transcriptional profiling of quiescent muscle stem cells in vivo. Cell Rep 21(7):1994-2004. https://doi.org/10.1016/j. celrep.2017.10.037

Vandenburgh H, Kaufman S (1979) In vitro model for stretch-induced hypertrophy of skeletal muscle. Science 203(4377):265-268. https://doi.org/10.1126/science.569901

Vandenburgh HH, Karlisch P, Farr L (1988) Maintenance of highly contractile tissue-cultured avian skeletal myotubes in collagen gel. In Vitro Cell Dev Biol Anim 24(3):166-174. https://doi.org/ $10.1007 / \mathrm{bf} 02623542$

Vandenburgh H, Del Tatto M, Shansky J, Lemaire J, Chang A, Payumo F, Lee P, Goodyear A, Raven L (1996) Tissue-engineered skeletal muscle organoids for reversible gene therapy. Hum Gene Ther 7(17):2195-2200. https://doi.org/10.1089/hum.1996.7.17-2195

Vandenburgh H, Del Tatto M, Shansky J, Goldstein L, Russell K, Genes N, Chromiak J, Yamada S (1998) Attenuation of skeletal muscle wasting with recombinant human growth hormone secreted from a tissue-engineered bioartificial muscle. Hum Gene Ther 9(17):2555-2564. https://doi.org/10.1089/hum.1998.9.17-2555

Vandenburgh H, Shansky J, Benesch-Lee F, Barbata V, Reid J, Thorrez L, Valentini R, Crawford G (2008) Drug-screening platform based on the contractility of tissue-engineered muscle. Muscle Nerve 37(4):438-447. https://doi.org/10.1002/mus.20931

Verma M, Asakura Y, Murakonda BSR, Pengo T, Latroche C, Chazaud B, McLoon LK, Asakura A (2018) Muscle satellite cell cross-talk with a vascular niche maintains quiescence via VEGF and Notch signaling. Cell Stem Cell 23(4):530-543 e539. https://doi.org/10.1016/j.stem.2018.09.007

Vilquin JT, Marolleau JP, Sacconi S, Garcin I, Lacassagne MN, Robert I, Ternaux B, Bouazza B, Larghero J, Desnuelle C (2005) Normal growth and regenerating ability of myoblasts from unaffected muscles of facioscapulohumeral muscular dystrophy patients. Gene Ther 12 (22):1651-1662. https://doi.org/10.1038/sj.gt.3302565

von Maltzahn J, Bentzinger CF, Rudnicki MA (2011) Wnt7a-Fzd7 signalling directly activates the Akt/mTOR anabolic growth pathway in skeletal muscle. Nat Cell Biol 14(2):186-191. https:// doi.org/10.1038/ncb2404

von Maltzahn J, Jones AE, Parks RJ, Rudnicki MA (2013) Pax7 is critical for the normal function of satellite cells in adult skeletal muscle. Proc Natl Acad Sci U S A 110(41):16474-16479. https:// doi.org/10.1073/pnas.1307680110

Wang K, Wang C, Xiao F, Wang H, Wu Z (2008) JAK2/STAT2/STAT3 are required for myogenic differentiation. J Biol Chem 283(49):34029-34036. https://doi.org/10.1074/jbc.M803012200

Wang L, Shansky J, Vandenburgh H (2013) Induced formation and maturation of acetylcholine receptor clusters in a defined 3D bio-artificial muscle. Mol Neurobiol 48(3):397-403. https:// doi.org/10.1007/s12035-013-8412-Z

Wang L, Cao L, Shansky J, Wang Z, Mooney D, Vandenburgh H (2014) Minimally invasive approach to the repair of injured skeletal muscle with a shape-memory scaffold. Mol Ther 22 (8):1441-1449. https://doi.org/10.1038/mt.2014.78

Weintraub H, Tapscott SJ, Davis RL, Thayer MJ, Adam MA, Lassar AB, Miller AD (1989) Activation of muscle-specific genes in pigment, nerve, fat, liver, and fibroblast cell lines by forced expression of MyoD. Proc Natl Acad Sci U S A 86(14):5434-5438. https://doi.org/ 10.1073/pnas.86.14.5434

Wernig A, Irintchev A, Hartling A, Stephan G, Zimmermann K, Starzinski-Powitz A (1991) Formation of new muscle fibres and tumours after injection of cultured myogenic cells. J Neurocytol 20(12):982-997. https://doi.org/10.1007/bf01187916

Wilschut KJ, Haagsman HP, Roelen BA (2010) Extracellular matrix components direct porcine muscle stem cell behavior. Exp Cell Res 316(3):341-352. https://doi.org/10.1016/j.yexcr.2009.10.014

Wilschut KJ, Ling VB, Bernstein HS (2012) Concise review: stem cell therapy for muscular dystrophies. Stem Cells Transl Med 1(11):833-842. https://doi.org/10.5966/sctm.2012-0071

Wolf MT, Dearth CL, Sonnenberg SB, Loboa EG, Badylak SF (2015) Naturally derived and synthetic scaffolds for skeletal muscle reconstruction. Adv Drug Deliv Rev 84:208-221. https://doi.org/10.1016/j.addr.2014.08.011 
Wosczyna MN, Rando TA (2018) A muscle stem cell support group: coordinated cellular responses in muscle regeneration. Dev Cell 46(2):135-143. https://doi.org/10.1016/j.devcel.2018.06.018

Wosczyna MN, Konishi CT, Perez Carbajal EE, Wang TT, Walsh RA, Gan Q, Wagner MW, Rando TA (2019) Mesenchymal stromal cells are required for regeneration and homeostatic maintenance of skeletal muscle. Cell Rep 27(7):2029-2035 e2025. https://doi.org/10.1016/j. celrep.2019.04.074

Wu J, Matthias N, Lo J, Ortiz-Vitali JL, Shieh AW, Wang SH, Darabi R (2018) A myogenic doublereporter human pluripotent stem cell line allows prospective isolation of skeletal muscle progenitors. Cell Rep 25(7):1966-1981 e1964. https://doi.org/10.1016/j.celrep.2018.10.067

Xi H, Fujiwara W, Gonzalez K, Jan M, Liebscher S, Van Handel B, Schenke-Layland K, Pyle AD (2017) In vivo human somitogenesis guides somite development from hPSCs. Cell Rep 18 (6):1573-1585. https://doi.org/10.1016/j.celrep.2017.01.040

Xiao F, Wang H, Fu X, Li Y, Ma K, Sun L, Gao X, Wu Z (2011) Oncostatin M inhibits myoblast differentiation and regulates muscle regeneration. Cell Res 21(2):350-364. https://doi.org/ 10.1038/cr.2010.144

Xie L, Yin A, Nichenko AS, Beedle AM, Call JA, Yin H (2018) Transient HIF2A inhibition promotes satellite cell proliferation and muscle regeneration. J Clin Invest 128(6):2339-2355. https://doi.org/10.1172/JCI96208

Xu C, Tabebordbar M, Iovino S, Ciarlo C, Liu J, Castiglioni A, Price E, Liu M, Barton ER, Kahn CR, Wagers AJ, Zon LI (2013) A zebrafish embryo culture system defines factors that promote vertebrate myogenesis across species. Cell 155(4):909-921. https://doi.org/10.1016/j.cell.2013. 10.023

Xu J, Du Y, Deng H (2015a) Direct lineage reprogramming: strategies, mechanisms, and applications. Cell Stem Cell 16(2):119-134. https://doi.org/10.1016/j.stem.2015.01.013

Xu X, Wilschut KJ, Kouklis G, Tian H, Hesse R, Garland C, Sbitany H, Hansen S, Seth R, Knott PD, Hoffman WY, Pomerantz JH (2015b) Human satellite cell transplantation and regeneration from diverse skeletal muscles. Stem Cell Reports 5(3):419-434. https://doi.org/10.1016/j. stemcr.2015.07.016

Yablonka-Reuveni Z, Rivera AJ (1994) Temporal expression of regulatory and structural muscle proteins during myogenesis of satellite cells on isolated adult rat fibers. Dev Biol 164(2):588 603. https://doi.org/10.1006/dbio.1994.1226

Yaffe D, Saxel O (1977) Serial passaging and differentiation of myogenic cells isolated from dystrophic mouse muscle. Nature 270(5639):725-727. https://doi.org/10.1038/270725a0

Yao SN, Kurachi K (1993) Implanted myoblasts not only fuse with myofibers but also survive as muscle precursor cells. J Cell Sci 105(Pt 4):957-963

Yao CC, Ziober BL, Sutherland AE, Mendrick DL, Kramer RH (1996) Laminins promote the locomotion of skeletal myoblasts via the alpha 7 integrin receptor. J Cell Sci 109(Pt 13):31393150

Yartseva V, Goldstein LD, Rodman J, Kates L, Chen MZ, Chen YJ, Foreman O, Siebel CW, Modrusan Z, Peterson AS, Jovicic A (2020) Heterogeneity of satellite cells implicates DELTA1/ NOTCH2 signaling in self-renewal. Cell Rep 30(5):1491-1503 e1496. https://doi.org/10.1016/ j.celrep.2019.12.100

Yin H, Price F, Rudnicki MA (2013) Satellite cells and the muscle stem cell niche. Physiol Rev 93 (1):23-67. https://doi.org/10.1152/physrev.00043.2011

Yiu EM, Kornberg AJ (2015) Duchenne muscular dystrophy. J Paediatr Child Health 51(8):759764. https://doi.org/10.1111/jpc. 12868

Young CS, Hicks MR, Ermolova NV, Nakano H, Jan M, Younesi S, Karumbayaram S, KumagaiCresse C, Wang D, Zack JA, Kohn DB, Nakano A, Nelson SF, Miceli MC, Spencer MJ, Pyle $\mathrm{AD}$ (2016) A single CRISPR-Cas9 deletion strategy that targets the majority of DMD patients restores dystrophin function in hiPSC-derived muscle cells. Cell Stem Cell 18(4):533-540. https://doi.org/10.1016/j.stem.2016.01.021 
Zammit PS, Golding JP, Nagata Y, Hudon V, Partridge TA, Beauchamp JR (2004) Muscle satellite cells adopt divergent fates: a mechanism for self-renewal? J Cell Biol 166(3):347-357. https:// doi.org/10.1083/jcb.200312007

Zhang M, Guo B (2017) Electroactive 3D scaffolds based on silk fibroin and water-borne polyaniline for skeletal muscle tissue engineering. Macromol Biosci 17(9). https://doi.org/10.1002/ mabi.201700147

Zheng JK, Wang Y, Karandikar A, Wang Q, Gai H, Liu AL, Peng C, Sheng HZ (2006) Skeletal myogenesis by human embryonic stem cells. Cell Res 16(8):713-722. https://doi.org/10.1038/ sj.cr.7310080

Zhou W, He DQ, Liu JY, Feng Y, Zhang XY, Hua CG, Tang XF (2015) Angiogenic gene-modified myoblasts promote vascularization during repair of skeletal muscle defects. J Tissue Eng Regen Med 9(12):1404-1416. https://doi.org/10.1002/term.1692

Zhu P, Wu F, Mosenson J, Zhang H, He TC, Wu WS (2017) CRISPR/Cas9-mediated genome editing corrects dystrophin mutation in skeletal muscle stem cells in a mouse model of muscle dystrophy. Mol Ther Nucleic Acids 7:31-41. https://doi.org/10.1016/j.omtn.2017.02.007 